

xisin 







P1. XIVIIL.

TRITHOMANES RADICANS, SWARTC 


\section{FERNS OF KENTUCKY}

WITH

Sixty full-page Etchings and Six Wood Cuts,

Drawn by the Author,

ILLUSTRATING

STRUCTURE, FERTILIZATION, CLASSIFICATION GENERA, AND SPECIES.

BY JOHN WILLIAMSON.

L O U IS V I L LE, K Y.:

Printed by John P. Morton \& Co., W. Main Street. 1878 
Copyrighted by John Williamson: iS 7S.

R. ROWEL, ELECTROTYPER, LOUISVILLE. 


\section{PR.EFACE.}

The want of a popular hand-book on our native ferns induced the author to issue the present work. The great expense of getting up the illustrations no doubt prevented publishers from such an undertaking. The beautiful monograph of the Ferns of North America, by Professor D. C. Eaton, of Yale College, now in course of publication, will, when it is completed, form a most valuable contribution to Botanical Science. The only aim of the present volume, however, is merely to be a guide to the amateur ferngatherer, a book that can be carried in the pocket, and referred to at any time, whether in the woods or in the study. Pages are left blank so as to enable the student to make notes regarding the habitat and locality of ferns and flowering plants.

The works of Riddell, Short, Clapp, and others who have gone over probably the same ground, are scattered throughout the various periodicals published at that time. They are very difficult to get at, and entirely out of the reach of the amateur botanist. These early workers made no attempt to illustrate, sometimes mentioning the county where the specimens were found, seldom the exact locality. 
All their localities have been credited as far as could be ascertained with accuracy. In McMurtrie's History of Louisville, he gives Scolopendrium officinarum (Swartz), as found near Louisville, Ky. This is certainly doubtful.

The present work is not so full in localities as it ought to be, and it is the earnest desire of the author that local collectors should communicate with him regarding this matter, noting carefully the time and the place of finding any plant described in these pages - whether on the higher ranges; whether on the declivities, or in the valleys, in the damp, rich woods, or along the banks of streams; whether on trees, or overhanging rocks; whether the rocks are sandstone, limestone, or of igneous formation. Notes can not be too careful or minute.

This is merely a beginning of what can be accomplished with the aid of local collectors. We hope in a little time to be able to determine the locality and range of every species and variety indigenous to the State.

I now take this opportunity to thank my botanical friends for the kind assistance they have given me in this workMr. J. C. Martindale, of Camden, New Jersey, Mr. John H. Redfield, of Philadelphia, Prof. D. C. Eaton, of Yale College, Prof. Coulter, of Hanorer College, Indiana, I'rof. Hussey, of Purdue University, Lafayette, Ind., Mr. Chas. E. Faxon, and MIr. G. E. Davenport, of Boston. I am especially indebted to Mr. Davenport for his valuable hints regarding the nomenclature and for criticisms on the illustrations. 
I am also specially indebted to my friend Dr. E. S. Crosier, of this city, who has taken a great interest in the work since its beginning, for valuable assistance in the preparation of the text. Most of the descriptions have been carefully revised by him, a courtesy I greatly appreciate.

J. W.

Louisville, Kr., May i6, i 878 .

The Illustrations are etched on metal plates, afterward transferred to litlographic stone, thus enabling the work to be published at a much cheaper price than if the copies were printed direct from the plates. They were printed by the Louisville Lithographic Company, who are to be thanked for the interest they have taken in the matter, in getting clear and sharp impressions, in every respect as well done as if they had been printed direct. 


\section{CONTENTS.}





Structure, • . . . . . . . . . I I

Cultivation, . . . . . . . . . . . 15

Fertilization, . . . . . . . . . . 18

Collecting and Drying, . . . . . . . $2 \mathbf{I}$

Classification, . $\quad$. $\quad . \quad$. $\quad . \quad$. 24

Key to the Genera, . . . . . . 30

Genera and Species, . $. \quad . \quad . \quad . \quad . \quad . \quad 33$

Appendix, . . . . . . . . . 151

Index, ..$+ \quad \cdot \quad \cdot \quad \cdot \quad \cdot \quad \cdot 152$

(6) 


\section{FERNS OF KENTUCKY.}

\section{INTRODUCTION.}

TO the student of Nature the order of Filices, or Ferns, 1 is exceedingly interesting. On account of their graceful forms and curious organs of reproduction, they occupy a unique place among the families of the vegetable kingdom. Their wide distribution renders them general favorites. It is only within a few years, however, that the study of ferns has become popular; but, to the botanist they have always been objects of rare interest. It is difficult to imagine why they should be considered more attractive than flowering plants, unless it be on account of the great profusion of their bright and delicately-tinted green fronds, the gracefulness of their foliage, and their happy adaptation, when dried, to the purposes of winter decoration.

Who would think now of going to the country to spend a few days, or even one day, without first inquiring whether ferns are to be found in the locality? If the answer is in the affirmative, the party is soon formed. All the appliances for collecting and preserving the specimens are procured; and, on arriving at the journey's end, what a bustle there is to get down to the ravine, under the dripping rocks, where grow the delicate and almost transparent Trichomanes and feathery Lady Fern! 
Ferns are numerous everywhere in Kentucky. It is a well-known fact that every wild flower has its special habitat. Some are found on the highest knobs, some in the valleys, and others along the banks of streams. Calcareous cliffs are preferred by some species, while others grow more luxuriantly where sandstone is the prevailing formation. Ferns have a similar distribution. There are a few, however, which are widely diffused, and seem to be content with any situation. The Maiden-hair Fern (Adiantum pedatum) is one of the commonest as well as the loveliest of the fern tribe. What could be more charming, on a summer morning, than the sight of a patch of the Maidenhair Fern with its stems of polished jet, and its delicate foliage sparkling with dew-drops?

The geographical position of Kentucky, as well as its peculiar topography, traversed by sub-mountainous chains, serves to make it a splendid field for the fern-collector. About forty species are described as indigenous to the State. It is possible that if a careful search were made a few others could be added to the list. The region along the Rockcastle River and its tributaries furnishes a great number of species, especially the rarer forms peculiar to certain geological formations. The Asplenium Bradleyi and Trichomanes radicans are both exceedingly rare, and are indigenous to Kentucky. They are not reported as found elsewhere in the United States, except in Alabama and Tennessee; but I have no doubt that they will be discovered in other localities. The vast region embracing the Appalachian chain of mountains, with its numerous spurs and deeply-shaded defiles, is peculiarly the home of ferns preferring shade and moisture. We are haplyy to be able to include among the Kentucky ferms the beautiful Climbing Fern (Lygodium palmatum), found in Laurel and 
Rockcastle counties, which is only occasionally met with so far westward and southward.*

Ferns are quite generally distributed over the surface of the globe. In the tropics they form a very characteristic feature of the vegetation. They are found in Greenland, in Iceland, at the North Cape, and throughont all temperate regions; but it is in the tropics that they attain their maximum size. Here, only, they assume a tree-like form. The horticultural department of the United States Centennial Exposition afforded American botanists a fine opportunity for the study of this curious, palm-like plant. Speaking of the 'Tree Fern, Darwin says: "In some of the dampest ravines Tree Ferns flourish in an extraordinary manner; I saw one which must have been twenty feet high to the base of the fronds, and was in girth exactly six feet. The fronds, forming the most elegant parasols, produced a gloomy shade, like that of the first hour of night." (Voyage of a Naturalist, Am. Ed., page I44.) In the early ages of the earth's history the Tree Fern must have been widely distributed, as its remains form a striking feature of some

* Mr. J. H. Redfield, of Philadelphia, has made a valuable contribution to the "Geographical Distribution of the Ferns of North America," in which the ferns inhabiting this country are arranged in six geographical divisions: I. Cosmopolitan: Widely distributed over the globe, in both the temperate and tropical regions. II. BOREAL: Inhabiting (with a few exceptions) the northern portion of the United States, British America, and Greenland. III. APp'ALACHIAN: Extending throughout the mountain and hilly regions of the states east of the Mississippi. IV. PACIFIC: Extending along the western border of the continent, from Alaska to California, and appearing in the Rocky Mountain region. V. New Mexico: Inhabiting the Central Mountain regions of New Mexico and Colorado. VI. Tropical: Inhabiting the border of the Gulf of Mexico, most of the species extending into the West Indies and Tropical America. (See Bulletin of the Torrey Lotanical Club, vol. vi, page I.) 
geological formations, especially the coal measures. Here, on our mantel-shelf, is a beautiful specimen of fossil fern, with all the characters distinctly marked. It is just as perfect as the living plant. What a history this specimen reveals to us, carrying us back through the dim, primeval ages to the very dawn of life upon the globe!*

From a strictly utilitarian point of view, very little use has been made of ferns, the root of the Male Fern alone furnishing the materia medica with a drug of some value. The true lover of ferns is not troubled with this lack of utility. The woods and glens and mountains are replete with objects of interest, whether seen with the eye of a botanist or of an amateur. He finds treasure-trove in every patch of ferns. Every plant; whether dried for household decoration, or simply named and classified, will recall the quiet loveliness of nature whenever the mind is rexed with worldly care. The window, with its store of living plants, the parlor wall, ornamented with vines, the fernalbum, filled with carefully prepared specimens, all serve to tell the story of their discovery. The Climbing Fern is there, reminding him of the long tramp among the hills; the little Bladder Fern, recalling the visit to the woodland spring, where it was gathered from the crevices of the dripjing rocks, and where, from the overhanging ledge, he attempted to trace the trailing root of the Polypody, or watched the Lady Fern unfolding its scroll of delicate tissues.

* Prof. Leo Lesquereux has recently described and figured twenty fossil ferns belonging to the Tertiary lilora of the United States. (See Hayden's Geological Survey of the Territories, vol, vii. 1878.) 


\section{STRUCTURE.}

What is a Fern? The vegetable kingdom is divided into two great classes, Phænogamia (flowering plants) and Cryptoganila (flowerless plants). The ferns belong to the latter class. The Royal Fern (Osmunda regalis) is often called the Flowering Fern; but this is a misnomer, as no ferns produce true flowers. The fruit, or rather fertilizing organs of the fern, are peculiarly situated, and have a very showy appearance, especially when fully developed; whence the name of Flowering Fern.

A fern can be easily distinguished from all other plants by the texture of the foliage, by the peculiar character of the veins, and more especially by the position of the fertilizing organs. On the under side of the leaf are situated a number of dark brown spots, some on the edge of the leaf, some at the center, and others scattered irregularly over the surface. These are the organs of fructification, and are common to all ferns. There are a few exceptions, however, in the manner of the arrangement of the fruitspots. The Sensitive Fern (Onoclea scnsibilis) furnishes a very good example of this exceptional method. Toward the end of summer it sends up from the root a spike resembling that of a flowering plant in fruit. (Plate XL.) This spike of fruit-like bodies is technically called the fertile frond, while the other, which is green and leaf-like, is termed the sterile frond. The fertile frond, or leaf, of most ferns is more contracted than the sterile, and the morphological law governing the conversion of leafy tissue 
into fruit is here well exhibited. (See Plates L, LI, and LII.)

Another characteristic feature of true ferns is presented in the unfolding of the leaf. In its youngest state it is curled up in a circinate fashion; and, as it comes up slowly through the leaf-mold, it gradually unfolds its scroll-like form until it reaches its last delicate leaflet, and soon afterward assumes an appearance the most graceful and beautiful in the vegetable kingdom. The Adder's Tongue Fern (Plate LIX), and the Moonwort Fern (Plate LVII), are exceptions to this rule; but, to say the least, they hold a doubtful place among the true ferns.

The frond, or leaf of a fern, differs from that of flowering plants in this-the latter performs only a foliage office, having no connection with the fruit-bearing organs, while the former bears the organs of fructification, exercising, at the same time, the functions of the leaf. However, the terms are almost synonymous, and in our discussion of the subject we may use the term leaf as well as frond. Prof. Sachs, one of the greatest living authorities on vegretable physiology, seldom uses the term frond.

The arrangement of the veins of the leaf, as has already been mentioned, is very different from that of ordinary plants. Having their origin at the mid-rib of the leaf or leaflet, they proceed by successive bifurcations toward the margin. By decolorizing a plant in a solution of chloride of soda, this peculiar structure of the leaf, as well as the arrangement of the fruit-spots, will readily appear.

Various terms are used in lescribing ferns, which it will be necessary to explain. A clear comprehension of these will enable the student to understand the written descriptions at once, and to determine the exact relations of any fern without the aid of an illustration. With this end in 
view I have prepared a plate, with several diagrams, giving most of the terms used in description. See Plate I.

The Root (Plate I, figure I), represents an underground stem or rhizoma of the common bracken (Pteris aquilina), after Sachs, showing the remnants of the old and decayed, as well as the young and living leaves. It is a very characteristic root-stock. An examination of the plates will enable the reader to recognize the different kinds of roots, a general description of which is given by Moore: "The proper roots of ferns are fibrous, and they proceed from the under side of the stem, which assumes a creeping mode of growth; but when the stem is erect they are produced toward its lower end on all sides indifferently, and proceed from among the bases of the decayed leaves. The stem of a fern forms either an upright stalk, called a caudex, which in our species seldom elevates itself above the surface of the ground, but in certain exotic ferns reaches from thirty to fifty feet or more in height, and gives a tree-like character to the species; or it extends horizontally either on or beneath the surface of the soil, and forms what is called a rhizome or creeping stem."*

The Leaf. (Plate IV.) The lower portion of the leaf is termed the stipe, and is somewhat analogous to the leafstalk of flowering plants. 'The upper part is more properly termed the frond, and is the fruit-bearing portion. The stipe may be simply a continuation of the root-stock (Plate I, figure 1), or it may be jointed (articulated), as shown in Polypodium (Plate IV). This is an important character in the classification of ferns. Leaves are either simple or compound. They are simple when undivided; compound when cut or parted into segments or lobes. Nearly all of the ferns have compound leaves.

* Popular History of British Ferns, page I 2. 


\section{DESCRIPTION OF PLATE I.}

Figure $\mathrm{r}-$ Root of Pteris aquilina (Sachs).

" 2 -Simple leaf, with wavy outline.

"3-Pinnatifid leaf.

" 4-Pinnate leaf.

" 5-Bi-pinnate leaf.

"6-Tri-pinnate leaf.

“ 7-Somewhat wedge-shaped leaf, showing the venation.

Figure 8-Serrate and ciliate leaf.

"9-Winged leaf.

" Io-Scaly and circinate leaf, unfolding. 



W 



\section{CULTIVATION.}

In whatever light we may view the study of the fern tribe, we are apt to be somewhat enthusiastic. It is by no means necessary to spend much money in the cultivation of ferns. A strong square or oblong case will answer the purpose very well. It may be elaborate, and in keeping with the other furniture in the room. This question, however, may be left entirely to the taste of the owner. A case well filled with ferns, in a healthy condition, is an endless source of enjoyment. You are sure to visit it every morning to watch the new fronds unfolding their downy heads, and to mark their growth day by day. In the far corner, where you least expected it, you observe a new one peeping above the soil. This is followed by a regular succession until you discover, when it is probably too late, that your case is too small. A case is almost indispensable to any one desirous of making ferns, in all their phases, the subject of careful study. The spores, when ripe, are scattered all around, and a few of them are sure to germinate.

The etching of the young fern (Plate II, figure 6) was drawn from a specimen taken from our own fern-case. These delicate, flat bodies are attached to the glass of the sides or to the root-stocks of other ferns. A fern-case is also very useful for preserving the plants when newly collected, if it be desirable to examine them carefully before placing them within the drying papers.

Fern-cases are usually called Wardian cases in honor 
of Mr. N. B. Ward, of London, who was the first to cultivate ferns in small, close cases, suitable for a small room or parlor. The size of the case should not be less than twelve by twenty-four inches. The box for holding the soil should be four and a half or five inches deep, lined with zinc or asphaltum; the height of the glass, twelve inches, and the roof, nine inches. In a case of these dimensions a fern with fronds twenty-one inches in length may be grown. The same proportions may be observed in making larger cases, except that very little increase in the depth of the box for holding the soil will be required. One of double the size, or eighteen by thirty-six inches, will make a handsome ornament for the room. Doors may be made for it, thus enabling you to examine the plants as often as desirable, removing, from time to time, the brown and withered fronds, and destroying the slugs and parasites which infest the plants. Some fern-growers recommend that the case be kept air-tight. 'The plants will doubtless grow well enough, but you will be denied the pleasure of examining them closely, and the glass will always be obscured with moisture.

The character of the soil is of very great importance. Healthy plants require an appropriate soil. In the Wirdian case first lay on the bottom, to the depth of one inch, any drainage material, such as broken pieces of crockery, or small bits of brick about the size of a marble; then fill the wooden box with soil. Some prefer a mixture of fibrous peat and sand, while others choose a light loam. Let the soil be entirely free from worms and slugs. In a large case there is a fine opportunity of showing good taste in the manner of planting the ferns. A lady friend, who takes great interest in her fern-case, has it beautifully arranged every winter. She manages to have the prettiest 
miniature forest imaginable-little moss-covered cliffs and dells, with fragments of decayed stumps overgrown with trailing lycopods and partridge-berries. There is no rule for arranging or growing ferns, any more than in the case of flowering-plants. In the case they do not require to be watered often, since very little evaporation is going on, just as in a damp and shaded wood. Some ferns are better suited for this sort of culture than others. In describing the species special attention will be called to this subject.

Nearly all our native ferns can be successfully cultivated in the open air in a city garden, provided it is kept moist and well shaded. A northern aspect is better than any other; but, without being well sheltered, the fronds will be apt to get broken and tangled, and become less graceful than in their native woods. A gentleman in the city of Louisville has been very successful in the cultivation of ferns in the open air. He has two circular mounds composed chiefly of leaf-mold from the woods. With the exception of some of the rock-ferns, he has growing in these mounds nearly all the ferns indigenous to the State. From early spring till late autumn these mounds present a scene of the most luxuriant vegetation. The graceful Lady Fern waves its feathery fronds, entangled with the veil-like form of the Maiden-hair; the Shield Ferns, the Spleenworts, the Osmundas, and the Bladder Ferns all grow most luxuriantly. The Sensitive Fern seems to be in its special paradise, with abundance of moisture and good, rich soil. Along with the ferns, making the spot still more beautiful, are a great many of our common wild flowersthe hepatica, the spring beauty, the celandine poppy, the the shooting-star, the stellaris, the mertensia, and a dozen others, rivaling in sweetness and beauty the more pretentious products of the greenhouses. 


\section{FERTILIZATION.}

The subject of the fertilization of ferns is as interesting as it is difficult of comprehension. In a book of this kind, intended for popular use, it will be impossible to go into all the details of the subject. I will, therefore, only give an outline of the process of fertilization, as it is at present understood by the best authorities. In his "Text-book of Botany," Prof. Sachs has given a very elaborate account of the fertilization of ferns, with illustrations, a few of which I have copied.

The first question to be discussed relates to the form and nature of the fertilizing organs. As I have already said, they are generally situated upon the back of the leaf or frond. With the aid of a pocket lens any one can see their exact position, whether on the margin of the leaf or at its center; whether they form round, horse shoe-like, or elongated patches. All these distinctions are very important in classification; and, when their significance is once understood, the student will be able to classify, the individual members of any genus, native or exotic. It is, however, impossible to determine the form of the organs of fertilization without the aid of a microscope; but it need not be of very high power.

The term sonus (a heap) is used in describing a single patch; the plural, sori, in describing a number of these patches. When the fertile frond is observed under the microscope, the sorus is found to be composed of a number of beautiful objects, ornamented with something like a 
spiral spring. These are termed the sporangia, or sporecases. When the sporange is ripe this elastic spiral spring breaks, scattering the contents (spores) in a thousand directions, as the pollen in flowering plants. A great many ferns have a delicate membranous covering for the little patches; this is the indusium or involucre. The form of the indusium is a characteristic feature in the classification of ferms. Sometimes it is linear, sometimes round, and sometimes fringed. In describing the several species this will be more particularly mentioned. Some ferns, as the common Polypody and Beech Ferns, are without any indusium, but these are exceptional cases.

When the spore is set free it alights on some convenient place, and germination, or rather budding, then commences. Some spores will germinate in three or four days, while others will require several weeks. 'The germination of a fern-spore is very different from that of the seed of a flowering plant or of an ordinary tree. With proper heat and moisture a young oak will be developed from an acorn planted in the soil, but the true fern requires two generations for its development. The minute, almost invisible spore bursts, its contents bud and form new cells; these cells continue to enlarge, and eventually become a flattish, heart-shaped body, technically called the prothallus. The prothallus may be compared to a flower, since it contains the fertilizing organs, antheridia, the male, and archegonia, the female. The development of the spore, in its various stages, is represented in Plate II.

A number of small roots are formed beneath the prothallus. These roots are mere hair-like bodies, each consisting of a single tube, and quite transparent. After the archegonium is fertilized a bud is formed, and from this bud the tender and delicate frond of the fern is unfolded. 


\section{DESCRIPTION OF PLATE II.}

Figure I-Sporangium opening (Hooker and Bauer).

" 2 -Spores.

"3-loung prothallus, growing from the spore (a) (from nature).

“ 4-Antheridia with antherozoids escaping (Sachs).

" 5-Archegonia (Sachs).

" 6-Developed prothallus with young fern (from nature).

The figures are all highly magnifict. 


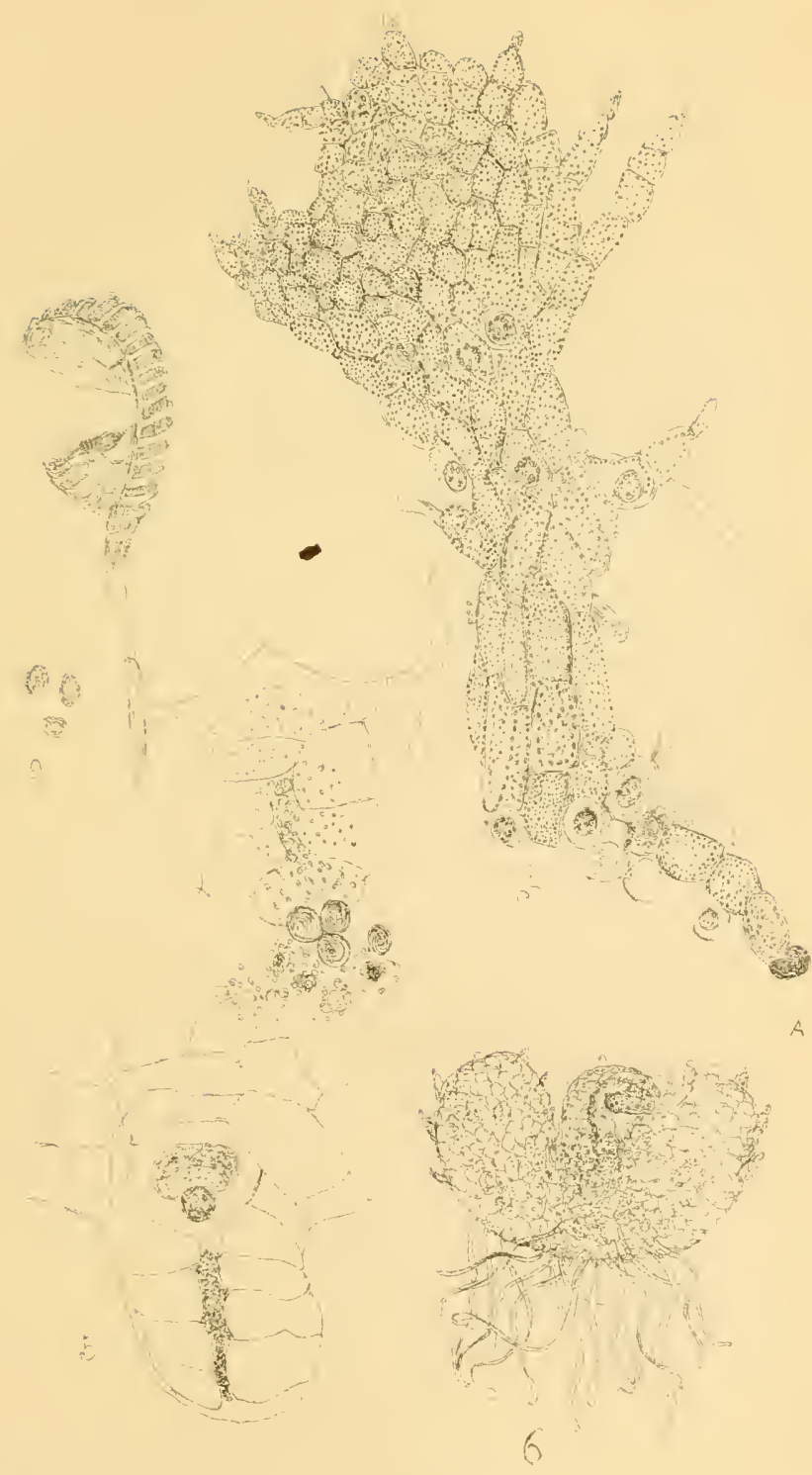





\section{COLLECTING AND DRYING.}

It will scarcely be necessary to say much about collecting and drying ferns, as nearly every reader of this book has had at least some experience in this line. It is very difficult to dry wild-flowers well, especially those which are thick and succulent; but ferns are so thin and delicate that any ordinary book will, to some extent, answer the purpose. Boards, however, are better-two boards about eighteen inches long, ten inches wide, and half an inch thick, with cross pieces at the ends, to prevent warping; plenty of soft, porous paper (carpet paper), and two leather straps. Add to these a long tin box, for preserving the specimens, and the outfit is complete. See that the specimens you select are perfect, by examining the backs of the fronds and observing whether the fruit-patches are well developed-in a word, whether they are characteristic examples of the plants you wish to preserve. The advanced student will probably select a number of fronds, showing different stages in the life of the plant; but the beginner should obtain the specimen apparently most characteristic, including the root, if not too large. If it is wanted for transplanting, it should be removed carefully, with plenty of its native soil.

The proper way to make a herbarium is this: select a specimen, characteristic both of the species and genus, well formed in every respect, with every leaflet perfect; if the root is to be taken, remove the soil carefully, without destroying the delicate rootlets; next place the plant be- 
tween the papers, and, if too large for the sheets, fold it gracefully, so as to show the under side of the frond, thus serving the double purpose of getting a large plant within the papers, and of showing the fruit-dots, which characterize the genus. (Plate XLVI.)

On reaching home, after an excursion, unfasten the boards at once, change the paper, and straighten out all the irregularly folded fronds, while they are yet pliant. Then place the plants under heavy pressure by means of a screw-press, or weights; repeat the process of changing the papers and examining the plants for several days, until they are thoroughly dried. Flowering-plants are much more difficult to manage. 'The quicker ferns are dried the better. After being thoroughly dried, they are to be named, and placed permanently upon a large sheet of white paper, sixteen and a half by eleven and a half inches. The plant, placed at the center, is either fastened down with fine white glue, or allowed to lie loosely on the paper, to be made secure afterward with narrow strips of paper across the stem in several places, glued at the ends. This must be done carefully, so as not to allow the strips to mar the beauty of the plant. We have seen a fine collection of California ferns, mounted in this way by a lady, which not only displayed good taste, but produced a very beautiful effect. In the right-hand corner a label is generally fixed, giving the name of the plant, when and where collected, and the name of the collector. (Plate IV.) The sheet containing the specimen is next to be placed within the genus cover. 'Thus, Asplenium ebeneum, Asplenium 'Trichomanes, Asplenium Ruta-muraria, etc., representing separate species, are to be placed in the same genus cover. 
A fern-herbarium will be a source of great pleasure. Every plant has a history of its own, recalling the scenes where it was collected, and all the attending circumstances. Every overhanging ledge, every wild mountain side, every deep ravine, has its representative. 


\section{CLASSIFICATION.}

The first systematic arrangement of ferns may be attributed to Linneus, the great Swedish naturalist, who laid the groundwork of our present system, based on the position and grouping of the sporangia. The form and arrangement of the spore-cases, the character of the covering or indusium, and the venation of the fronds serve to determine the proper methods of classification now in use.

The earlier systems of classification, though in many respects imperfect, were generally characterized by a degree of accuracy which was very remarkable when we consider the limited facilities at hand at that time for making careful microscopic investigations into the minute structure of the fertilizing organs. Of the thirty genera established by Swartz, at the beginning of the century, all but two are still retained in the botanical works of the present day. The writings of Presl, of the University of Prague, of Sir I. E. Smith, of England, of Fèe, of Strasburg, and of Bermhardi have done much to render the task of classifying ferns less difficult for those who have studied the subject in modern times. Dr. Mettenius, of Leipsic, and Sir IV. J. Hooker, of Kew, have given us the latest reliable works on the subject of the classification of ferns in general, and their systematic arrangement into genera and species.

In his excellent "'lext-Book of Botany," Prof. Sachs, of the University of Wursburg, makes the following remarks on this subject: "The systematic classification of ferms, as generally given in the hand-books, is based artificially on 
the form and nature of the mature sporangia for the families, and of the sorus for the genera. It appears certain that the Hymenophyllaceæ contains the lowest forms most nearly allied to the Muscinex. The Hymenophyllacex probably forms the starting point for two or more series of families."

Sachs establishes seven families for all the known ferns, the Adder's Tongue and Moonworts (Ophioglossacee) being excluded from a place among the true ferns and assigned to a separate class. Prof. Daniel C. Eaton, of Yale, the best authority on ferns in this country, adopts a classification which is essentially the same as that of Sachs.*

The following are the seven families of Sachs, with such representative ferns as are indigenous to this country:
I. Hymenophyllaces,
(Trichomanes radicans).
2. Gleitcheniace
3. SCHIZÆACEA,
(No American fern).
4. Osmundacee,
(Lygodium palmatum).
5. Marattiace:,
6. Cyatheaceæ,
7. Polypodiacee,
(Osmunda regalis).
(No American fern).
(No American fern).
(Polypodium vulgare).

If the Ophioglossace. is included, the Ophioglossum vulgatum will represent the family in America, leaving the second, fifth, and sixth without any representative in this country.

The classification which I have adopted in this book is that of Prof. D. C. Eaton, as given in the last edition of Gray's Manual, by whom the ferns of the United States are arranged in four sub-orders, as follows:
I. Polypodiace e,
2. SCHIZÆACEÆ,
3. Osmundacee,
4. OPHiOglossaceæ.

* See article "Ferns" in Johnson's Cyclopedia, vol. ii, p. 7 r. 
'The general characteristics of these sub-orders, with the addition of Hymenophyllacer, which, at the time Prof. Eaton wrote, was supposed to be unrepresented in this country, can be better shown by figures representing the different forms of the sporangia, upon which these divisions are based:

POLyPodiace. E.-Sporangia with a vertical (i.e. longitudinal), incomplete, many-jointed ring, and therefore splitting transversely. The sori either cover the surfaces and veins of both sides of the leaf, or are confined to one side alone; are either distributed along the whole course of the veins, or are terminal on a vein or at a fork; are either naked or covered by an indusium. (Fig. I.)

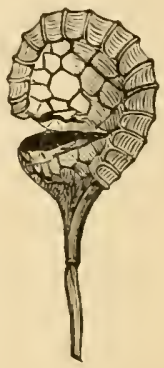

Fig. 1.

HYMENOPHYLACEA. - Sporangia with an oblique or transverse complete ring, opening by a longitudinal slit; they are formed on a prolongation of the fertile veins, projecting beyond the margin, and are surrounded by an urn-


P'rotile view. Fig. 2, Front viow. shaped indusium. The fertile end of the reins of the leaf projecting beyond its margin, or the columella, elongates ly intercallary growth, and the newlyformed sporangia are, in a corresponding manner, produced in a basipetal succession. They are arranged on a spiral line on the columella. The sessile sporangia are biconvex, and are attached to the columella by one of their convex surfaces (Sachs). (Fig. 2.) See also Plate XLVII. 
SCHIZÆACE.E. - Sporangia ovoid or pear-shaped, sessile or shortly stalked, having a complete, transverse, articulated ring at the apex, which is cap-like and circular, and it therefore splits longitudinally. In our typical genus Lygodium the two pinnæ at the base of each primary branch of the leaf have a flatly expanded lamina definite in its growth. The fertile segments are spicate, and each bears on its under side two rows of sporangia, each of which is placed in a pocketshaped outgrowth of the tissue of the leaf (Sachs). (Fig. 3.) See also Plate XLIX.

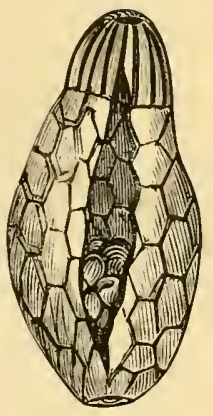

Fig. 3.

OSMUNDACEÆ. - Sporangia globose, shortly stalked,

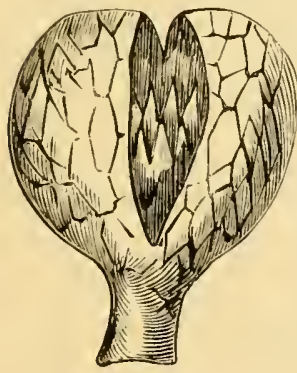

Fig. 4. opening into two valves by a longitudinal slit. They are unsymetrically rounded, and, instead of a ring, are furnished on one side with a peculiarly developed group of cells beneath the apex (Sachs). In our genus, Osmunda, from the distribution of the sori upon the surface of the leaf, instead of upon the veins, the fertile leaves become contracted and no longer resemble the sterile fronds. (Fig. 4.) See also Plate LI.

OphioglosSACEæ.-Sporangia spiked, destitute of a ring, naked, coriaceous and opaque, not reticulated, opening by a transverse slit into two valves, discharging copious powdery spores. According to Sachs the sporangia of Ophioglossa-



Fig. 5 . cere are so essentially different from those of other ferns 
that a separate classification is necessary. (Fig. 5.) See Plate LVIX.

The sub-order Polypodiace embraces what are generally termed the true ferns, and is by far the largest group, not only of ferns indigenous to the United States, but of all existing species. The arrangement of the fruit-dots is so varied in the genera of this family that Prof. Eaton has separated it into five tribes:

I. POLYPODIE⿺.

2. Pteridek.

3. Asplenieæ.

The following table, with references to the plates, will enable the student to understand more clearly the relationship of the genera to the tribes to which they belong:

Tribe I. Polypodiee. Fructification on the back of the frond; no indusium; stipes articulated to the root-stock.

Polyponium, . . . Plates III and IV.

TRIBE 2. PTERIDEÆ. Fructification marginal or intermarginal; provided with a general indusium; stipes not articulated; veins free in our species.

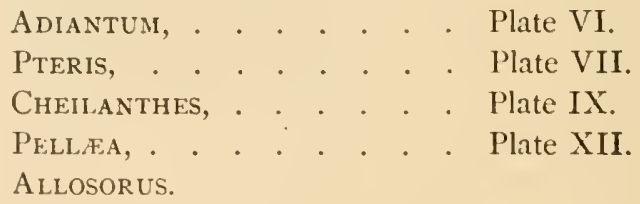

Tribe 3. Asplenif. F. Fructification elongated, covered by a special indusium which is attached by one side to the fertile vein; stipes not articulated.

WOODWARDIa.

Asplenium, . . . . . . Plate XiII.

SCOLOPENDRIUM.

Camptosorus, Plate XXIV. 
Tribe 4. Aspidies. Fructification round, provided with a special indusium, rarely naked; stipes not articulated.

Phegopteris, . . . . . Plate XXVI.

Aspidium, . . . . . . Plate XXIX.

CYSTOPTERIS, . . . . Plate XXXVII.

STRUTHIOPTERIS.

Onoclea, . . . . . Plate XL.

Woodsia, . . . . . Plate XLII.

TRIBe 5. Davalliee. Fructification at the ends of the veins, with an indusium attached at the base and opening toward the margin of the segment.

Dicksonia, . . . . Plate XLV.

The remaining sub-orders are represented in the United States by only a few genera, and have no tribal divisions.

Sub-order Hymenophpllacee:

Trichonanes, . . . . . Plate XlviI.

Sub-ORder SCHIZÆACEæ:

SCHIZÆA.

Lygodiun, . . . . . Plate XLIX.

Sub-ORder Osmundaceæ:

Osmunda, . . . . . Plate LI.

Sub-ORder Ophioglossacee:

Botrychiun, . . . . . Plate LV.

Ophioglossum, . . . . Plate LVIX.

For a more detailed account of the classification and description of the ferns of North America, I would refer the reader to the excellent article, "Filices," by Prof. Eaton, in the latest edition of Gray's Manual, and to his splendid monograph on the "Ferns of North America," now in course of publication. 


\section{KEY TO THE GENERA.}

A. Sporangia dorsal or marginal, surrounded by an elastic ring, reticulated and pellucid, opening transversely and irregularly.

POLYPODIACE\&.

Sori without an indusium and not covered with the reflexed margin of the frond, . . . . . . . . . POlyPodiex.

Polv poulium. Sori roundish, in one or more rows on each side of the midrib; stipes articulated with the root-stock. (Page 33, Plate III.)

4: Sori marginal or intermarginal, with an indusium, or covered by the refe.r margin of the frond, . . . . . . . . . . . . . PTERTDEA.

Aliantum. Sori oblong or roundish, marginal; stipes black and polished. (I’age 39, Plate VI.)

Pteris. Sori continuous at the margin, connecting the tips of the free veins; indusium formed by the reflexed margin; stipes light colored. Page 4 , Plate VII.)

Cleilanthes. Sori minute at the ends of the veins; indusium continuous or interrupted, formed by the reflexed margin; stipes near the base brown or black, shining. (Page 45, Plate IX.)

Pellaen. Sori on the upper part of the veins; indusium membranaceous, continuous, rarely wanting; stipes generally dark colored. (Page 51 , Plate XII.)

Allosorus. Sori roundish or elongated, extending far down the free veins, covered at first with the reflexed margin; stipes light colored.

20: Sori oblong or linear, the indusium attached by one side' to the lateral veins, apening at the other, . . . . . . . . . . ASPLENE.E.

Wooduardia. Sori forming a chais-like row on each side of the midrib; veins reticulated.

Aspleuium. Sori elongated, arising from lateral veins, opening toward the midrib; veins free. (Page 53, Plate XIII.)

Scolopeulvimu. Sori linear, confuent in pairs; indusium double, the two portions opening toward each other; veins free.

C'auptosorus. Sori irregularly scattered, partly on veins parallel and partly on veins oblique to the midrib, outer often in pairs; veins reticulated. I'age 75 , I'late XXIV.)

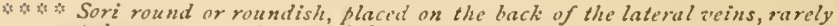
at the apex; mostly provided zuith an indusium. . . . . ASt'IDIEA.

pluegopteris. Sori round, rather small, with an obsolete or no indusium; stipes not articulated with the root-stuck; veins free. (Page 79, Plate XXVI.)

Aspidium. Sori roundish: indusium attached above the sori, orbicular or reniform; veins free. (Page 85 , Plate XXIX.)

Cyotopterix. Sori roundish; indusium attached below and partly under the sori, cunvex, acuminate; veins free. (I'age sos, Plate XXXíni.)

(30) 
Nituthinpteris. Sori round; indusium obscure, somewhat semicircular; fertile and sterile fronds unlike, fertile fronds pinnate; veins free.

OMorlea. Sori round, soon confluent; indusium thin and hood-like; fertile and sterile fronds unlike, fertile frond twice pinnate; veins reticulated. (Page 107, Plate XL.)

Woorisia. Sori roundish; indusium attached under the sori, more or less cut at the margin; veins free. (Page ir , plate XLII.)

$\therefore: * ;$ Sori roundish or transversely elongated, at the ends of the veins, with an indusium attached at the base, and opening toward the margin.

DAVALLIEA.

Dicksonia. Sori very small, marginal, with a somewhat two-valved, cupshaped indusium; veins free. (Page 117 , Plate XLV.)

B. Sporangia on a prolongation of the fertile vein, projecting beyond the margin of the frond, and surrounded by a cup-shaped indusium.

Triclumames. Sori narginal, within a cup-shaped indusium; the columella exserted and bristle-like; veins forked. (Page I2I, Plate X'LVII.)

C. Sporangia ovoid or pear-shaped, sessile or shortly stalked, with a complete circular ring forming an apical, cap-like zone, opening by a longitudinal slit. . . . . . . . . SCHIzÆACEÆ.

Scluizata. Sporangia naked, fixed in a double row on the fertile segments; sterile fronds, rigid, simple, or branched.

Lygoulum. Sporangia with a special scale-like indusium for each sporange, borne in a double row on the narrow spicate fertile segments; fronds leafy, climbing. (Page 127, Plate XLIX.)

D. Sporangia naked, globose, clustered on the margin of a transformed frond, with an obscure ring, reticulated and pellucid, opening by two regular valves. . . . . . OSMUNDACE.

Usmumda. Sporangia pedicillate in branching spikes upon the margins of the very narrow segments; veins free. (Page I3I, Plate I.I.)

E. Sporangia sessile, coriaceous, opaque, on the margin of a contracted frond, without reticulations or a ring, opening by a transverse slit into two valves; fronds not rolled up in the bud.

OPIIOGLOSSACEA.

Botrychium. Sporangia arranged on one side of a pinnate rachis; veins free, forked. (Page 139, Plate L, V.)

Ophioglossum. Sporangia cohering on a I-celled 2-ranked simple spike; veins reticulated. (Page I $_{4}$, Plate LVIX.) 









\section{GENERA AND SPECIES.}

\section{Plate III.}

\section{POLYPODIUM. Linnæus.}

GEN. Char.-Fruit-dots naked, round, on the back of the frond at the ends of the veinlets, arranged in one or two rows on each side of the mid-rib; stipes articulated with the creeping, scaly root-stock.

This is a very extensive genus, and is widely distributed over the entire globe. It is the typical genus of the tribe Polypodiex, and it is easily recognized by its having the fruit-dots naked, or without any covering (indusium). These are arranged on the back of the frond, and, in our species, are very regular and near the margin of the pinnules. Examined with a pocket lens before the disruption of the elastic ring, they have the appearance of globular masses of little berries. The veins are also very characteristic in this genus, branching from the mid-rib, twice or thrice forked, and always ending in little club-shaped points. Held between the observer and the light, especially after being decolorized, this peculiarity will be readily distinguished. Another characteristic of the genus is the articulation of the stipe or stalk with the root-stock. On examining an old plant, with a pretty thick rhizome, it will be found to be covered with rough knots, the old stalks, at their point of attachment, having left a series of scars, just as the leafstalks of some trees when they fall in autumn. 
The name Polypody means many-footed, and it has been explained to apply to the branching of their creeping stems, which have a fancied resemblance to Polypes.

Figure I shows two pinnules magnified about three diameters; figures 2, 3, and 4, sporangia and spores greatly magnified. 



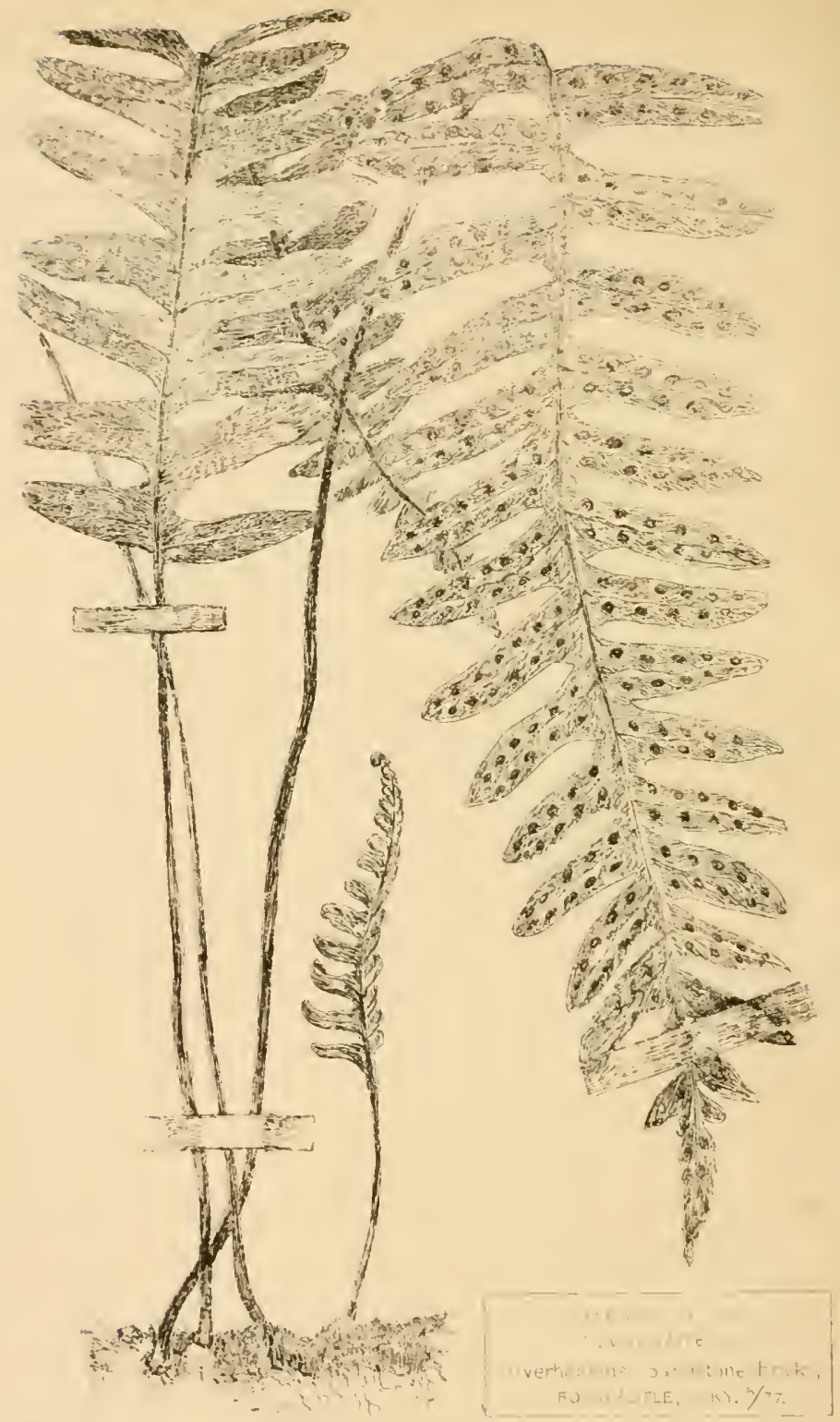


Plate IV.

\section{POLYPODIUM VULGARE. Linnæus.}

\section{Cummon Polypony.}

The Common Polypody is a typical species, having the characteristic creeping root-stock of the genus. It is generally found growing among the mosses on overhanging rocks, although it is rarely confined to any special habitat. In England and Scotland it often grows on the trunks of trees, and sometimes even upon the thatched roofs of cottages. Some specimens in my own collection were found on the banks of Loch Lomond, Scotland, growing on a dry stone wall, the thick rhizomes imbedded in the moss below. This fern has a wide geographical range, and in the United States belongs to the Appalachian division of Mr. Redfield's classification. In Kentucky it grows to perfection in Rockcastle and Laurel counties; also in Madison County (Short). I visited the former county in the middle of March, and was surprised to find this fern in such abundance, especially at this season. Every sheltered rock, whether on the hillsides or along the banks of streams, was literally covered. Thickly imbedded in a carpet of moss, it can be detached from the overhanging rocks in great masses. The average size of the full-grown plant is from eight to ten inches. The root-stock is densely covered with chaffy scales. The frond is oblong, somewhat lanceolate or alternate pinnatifid, the leafy portion commencing a little below the upper half of the frond; the divisions linear oblong, with a wavy outline, sometimes slightly serrated. The whole plant is smooth, and always has a fresh, dark evergreen appearance. In sheltered localities it remains green all winter. The articulation of the stem is shown in the illustration. 




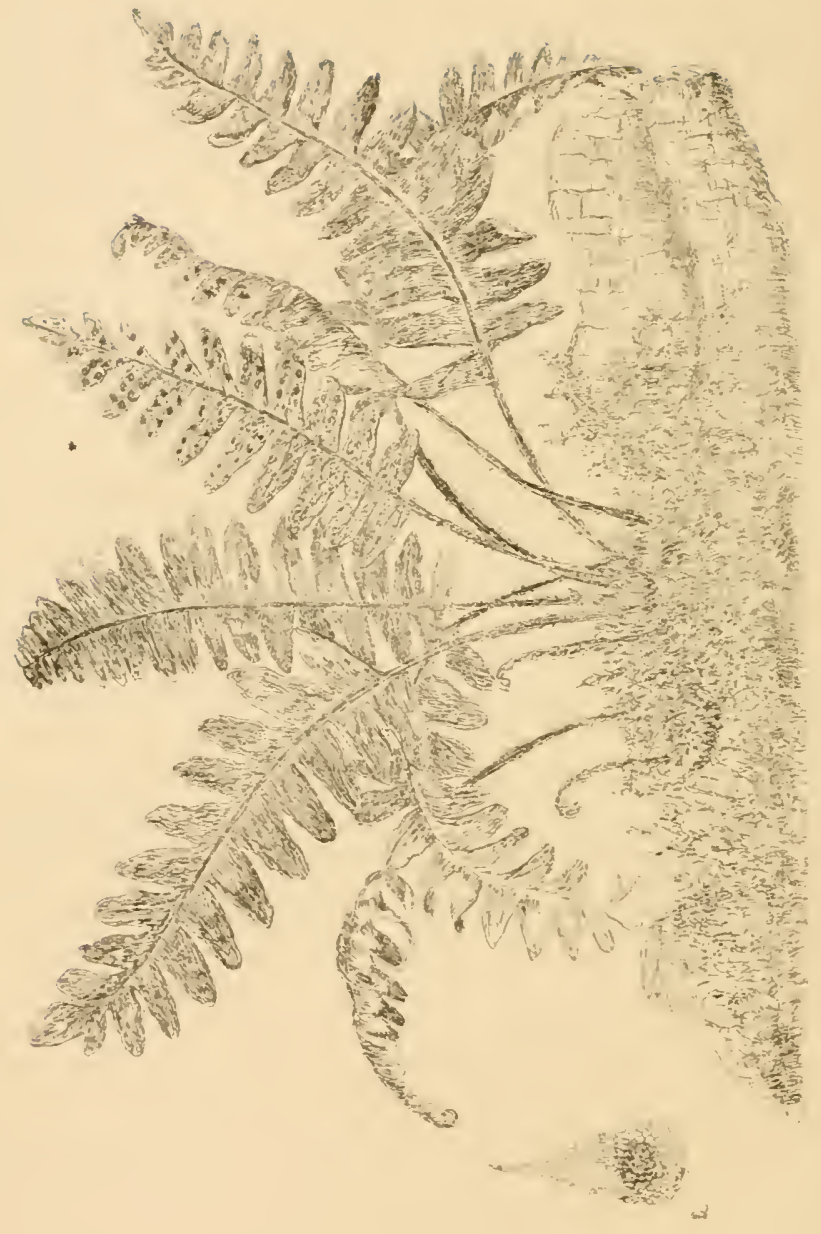


Plate V.

\section{POLYPODIUM INCANUM. Swartz.}

The Scaly Polypody.

This fern is essentially tropical in its distribution, growing in great abundance throughout the Southern States, but rarely extends so far north as Kentucky, and is occasionally found in Indiana and Illinois. It usually grows upon trees, but sometimes on overhanging rocks. Southward it is luxuriant on live-oaks, and, in this latitude, is found oftenest on the oak and sycamore. The illustration is from a specimen found near Rock Springs, Oldham County, growing upon a sycamore tree, extending along the trunk for the space of thirty feet, commencing about ten feet from the base. It grew mainly on the southwest side of the tree, and appeared to have a good foothold, having apparently existed there for years. The roots, of course, are in no way connected with the tree, as is the case with the mistletoe, being merely imbedded in the moss and earthy matter deposited upon the bark. It has been obtained at the mouth of Elk Lick, Kentucky River (Short); near Lebanon, Marion County (Knott); at Livingston, Rockcastle County; on Rough Creek, Grayson County; near Rockcastle Springs, Laurel County (Miss Rule); at Rock Springs, Oldham County; near Cumberland Gap, Bell County (Jordan); and in Hardin and Edmonson counties, in Kentucky, and upon oak-trees and cliffs near the Ohio River, in Perry County, Indiana (Smith).

Prof. Hussey says: "I found this fern in a very dry situation on the upper surface of the low cliff which borders the depression in which the mouth of Mammoth Cave opens. Standing with the back to the care, near its mouth, the rock 
on which this fern is found is to the right on the low cliff fifty or sixty feet above and a hundred yards toward Green River. The rock is not in sight in the summer on account of the dense foliage. Another locality is about twenty miles to the west, on a branch of Nolin Creek, near the old Iron Furnace, where it covers a large rock. In this locality it has large fronds, and they are very full of fruit-dots."

A curious feature about this fern is its great tenacity to life, resembling, in this respect, the Siluginella convoluta, a plant allied to the lycopods. When dry the fronds are contracted and curled up, apprarently utterly devoid of life; but the moment they are moistened they expand and become fresh and green again. Some specimens were sent to me from Perry County, Indiana, in February, which were all shriveled up and appeared to be dead. Upon moistening the moss about the roots the plants at once revived, and grew as luxuriantly as if upon their native trees. It has the same general appearance as the common Polypody, but is much smaller. The plant represented in the Plate is of natural size.

On the stipe and back of the frond are situated a great number of scales, giving the plant a rusty appearance. The tissue of the scale has a loose, cellular structure, resembling the indusium of some ferns.

It is a well-marked species, and can be readily distin guished. It is not easily cultivated in the Wardian case, but may be grown successfully with a little care. (Plate V., figure 2. Scale magnified.) 
Plate Vi.

\section{ADIANTUM. Linnæus.}

Gen. Char.-Fruit-dots oblong or roundish, marginal ; indusium formed by the reflexed margin of the lobes of the pinnules; stipes black and polished, bearing delicate, veil-like fronds.

This is a large and beautiful genus, characterized by its having the spore-cases situated on the reflexed margin of the leaflets. This reflexed margin serves the purpose of an indusium, or covering, the spore-cases being attached to the underside, and hence turned upside down upon the surface of the frond. All the plants have black, shining, wiry stems, variously branched, with the leaflets somewhat wedge-shaped, often fan-shaped, crenate, or fringed. The Adiatum is a favorite genus with the gardeners on account of its great beauty, its easy cultivation, and its convenience in giving variety to bouquets. A very handsome species, Adiantum Farleyense, has been lately introduced in our greenhouses. The common name of the fern is Maidenhair, and is applied indiscriminately to all the species, as well to the A. Capillus-Veneris, found in the South of England, as to our own A. pedatum. The general appearance of the plants, however, is quite different, although the characteristic features of the genus are common to both. 'They have the same black, wiry stems and branches, with leaflets spreading like an embroidered veil.

There are two species of Maiden-hair indigenous to this country-A. Chilense, Klf., a native of California, and belonging to the Mexican flora, and A. pedatum (Limnæus), very common in this region, belonging to the Appalachian group. 
Plate Vi.

\section{ADIANTUM PEDATUM. Linnæus.}

MAIDEN-HAIR FERN.

The Maiden-hair is one of the most common ferns in our Kentucky woods, and is most luxuriant in damp, secluded nooks, where the direct rays of the sun seldom penetrate. There is no danger that the enthusiastic ferncollector will ever be able to exhaust the supply of this lovely plant in our woods, since it is so plentiful every where. The only regret seems to arise from the impossibility of conveying home but a few of the many examples of this woodland fairy.

It has a creeping root-stock, sending up early in June a veil-like frond of branching leaflets. The upper edge of the leaflet is notched wherever the margin turns over to inclose the spore-cases. The stem is black and shining, dividing towards the top into two main branches. These are again divided, forming, when fully developed, a pedate, or somewhat horse-shoe-like frond. This fern is very suitable for general cultivation in the Wardian case, in greenhouses, or in mounds in the open air, if well sheltered from the sun. 'The Plate, on account of its small size, gives but an imperfect idea of what may be regarded as the loveliest of all our American ferns. Figure 2 shows part of a pinnule of natural size; figure 3 , a lobe of the pinne, magnified and laid open (after Hooker and Bauer). 


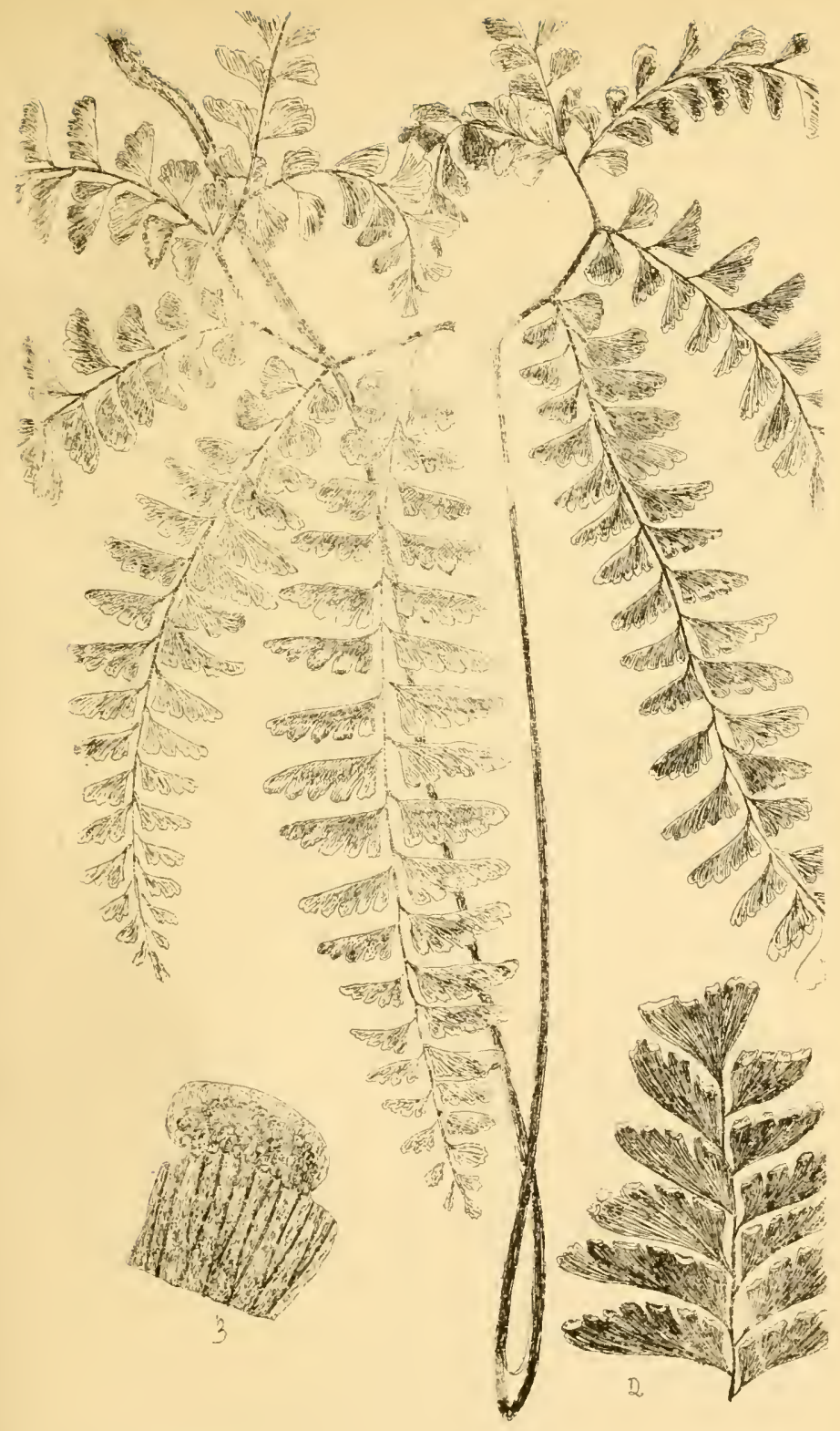








Plate ViI.

\section{PTERIS. Linnæus.}

GEN. Char. - Fruit-dots on the margins of the frond in a continuous line, the reflexed margin forming the indusium; sporangia attached to a vein-like receptacle which connects the tips of the veins; stipes light colored.

This is the typical genus of the tribe Pterideæ, and is widely distributed. It is characterized by its having the spore-cases arranged in a continuous line along the margins of the pinnules. The organs of fructification are covered by the reflexed margin of the leaflet, which forms a continuous membranaceous indusium.

The various species of this fern differ very widely from each other in form and color; some have the pinnules very long and linear, like ribbon-grass; others are beautifully tinted, resembling variegated leaves.

An examination of the underside of the leaf, with its reflexed margin, will always enable the student to determine the true character of this genus. It is closely allied to the genus Pellæa, which, in fact, was formerly included in it. There would seem, however, to be good ground for the distinction, and the best authorities have sanctioned the separation. Figure I, pinnules slightly magnified; figures 2 and 3 , sporangia and spores greatly magnified. (Hooker and Bauer); figure 4, reflexed margin laid open, showing the venation. 




\section{1

W.





ofy











\section{Plate Vili.}

\section{PTERIS AQUILINA. Linnæus.}

The Common Bracken.

The term Bracken is applied by some persons to all kinds of ferns. But the name appropriately belongs only to the Pteris aquilina. It is very properly referred by Mr. Redfield to his Cosmopolitan division, on account of its general distribution. It grows abundantly, both in the new and the old world. It is common on nearly all our Kentucky knobs, and is occasionally met with in the valleys, especially among the loftier hills. On the Alleghanies, in this country, and in the highlands of Scotland, the bracken often covers acres of ground, and such places become the favorite haunt of the deer. In Kentucky it is always found associated with the huckleberry, the mountain laurel, and other members of the heath family.

It is a strong, vigorous fern, often three or four feet high; the stout stalk having three wide-spreading branches, giving the whole plant a triangular form. On account of its robust habit it is not very attractive in a small fernery, and is, besides, not readily cultivated. In its native woods it is exceedingly picturesque, and is a striking feature of the vegetation. It is impossible to represent this fern well on a small plate.

Plate I, figure I (after Sachs), represents the root of the Pteris aquilina, giving a good idea of its manner of growth. 




Plate IX.

\section{CHEILANTHES. Swartz.}

Gen. Char. - Fruit-dots at the ends of free veins, covered, when young, by a mostly continuous indusium, formed by the reflexed margin of the lobe; low, hairy, sometimes woolly plants, with stipes brown or black, shining.

The species of Cheilanthes are very numerous, and are distributed over the tropical and temperate regions of the globe. The Cheilanthes fragrans, a dwarf bi-pinnate species, whose fronds have a pleasant odor like that of newmown hay, is found along the Mediterranean, and reaches as far north as Switzerland. Arabia, Abyssinia, South America, and the West Indies yield a variety of species. Three well-marked species are indigenous to the Northern United States, and several to the Pacific States and Mexico.

Some of the species of this beautiful genus have the underside of the fronds covered with a silvery or goldencolored powder, as in Gymnogramme. The fructification is somewhat similar to that of the Adiantum, but this apparent similarity disappears on close examination. In Cheilanthes the fruit-dots are arranged at the ends of the veins, close to the margin of the pinnule. This margin is turned over so as to form a lip, which then becomes the indusium. From this peculiarity of the indusium the generic name is derived-the lip-flower.

The Plate shows a pinnule slightly magnified; and figure 2 , a lobe greatly magnified. 







PLATE X.

\section{CHEILANTHES VESTITA. Swartz.}

ClóTHED Lip-FERN.

The ferns of this genus, at least those indigenous to the United States, are very strikingly marked with a great profusion of hairs, which cover the stalks and give them a rusty appearance. This plant, however, is less hairy than any of the other species found in this country. The frond is twice pinnate, lanceolate, with oblong pinnatifid pinnules, somewhat slender, usually seven or eight inches, but sometimes fifteen inches in height. The mature fronds appear to be crisped from the reflexed condition of the lobes of the pinnules. The hairs are flattened, and strongly articulated, with from three to five joints, a characteristic which is not readily perceived without the aid of the microscope. The C. restita is exceeding rariable in form and general appearance, which is probably due to local and climatic influences. It is rare in Kentucky, and does not appear to have been found by the earlier botanists of the State. It is chiefly confined to the mountain regions. Some fine specimens were obtained, last summer, by Dr. Crosier on Sweet Lick Knob, near Irvine, Estill County. Although growing in the greatest luxuriance upon the rocks near the summit, the plants seemed to be rather diminutive, as the largest fronds were scarcely more than four inches in length. This was probably owing to the exposed situation where they grew. It is quite hardy, and able to withstand long droughts, as its fresh, green appearance upon the parched declivities of Sweet Lick Knob sufficiently indicates. Prof. Hussey found it near the boundary line of Edmonson and Barren counties, growing upon sandstone 
rocks "around a small well-like depression, eight or ten feet deep, on the eastern part of the ridge in which Short Cave is situated, not far from Diamond Cave." The specimens from the latter locality are much larger than those from Estill County.

The Plate shows a plant of natural size, with the fronds in different stages of development. 






Plate XI.

\section{CHEILANTHES TOMENTOSA. Link.}

\section{WOOLLY LIP-FERN.}

This is the rarest as well as the tallest and handsomest of the lip-ferns. I have not been able to find it in this State, though Prof. Gray, probably on the authority of Dr. Short, attributes it to Kentucky, without mentioning any locality. It is doubtless indigenous to the State, since it has been found in the mountains not far from the border, both in Tennessee and North Carolina. It is probably the Nephrodium lanosum, of Michaux, who gives its habitat as "rocky mountains of Tennessee and North Carolina." I am indebted to Mr. C. E. Faxon, of Boston, for the plant I have figured, who informs me that "it came from the Holston River, Tennessee, where his brother collected a considerable quantity of it several years ago." Mr. Redfield writes me that "the best known locality is on the rocks along French Broad River, just on the boundary between North Carolina and Tennessee, where it is very abundant. Possibly it may recede farther West, and it is to be sought for, if any where, not far from Cumberland Gap, and along the southeast border of the State." It is highly desirable that local collectors should make an effort to decide the vexed question of its existence in Kentucky, and furnish us with the exact locality in all cases.

The best specimens of this plant which I have seen are not more than eight or nine inches in height, but I am assured that it is often found fifteen or twenty inches. The fronds are lanceolate, oblong, tri-pinnate, and densely covered with slender, whitish hairs. The upper side of the frond is of a dark green color, and much smoother than 
the under side, which is quite woolly. It has a tufted root, clothed with a profusion of long rusty hairs. The dark brown stipe is also hairy. The tri-pinnate character of the fern is not perceptible at first, on account of the numerous hairs beneath, concealing the delicate segments and lobes of the pinnæ. When the plant, however, is mounted on white paper and held up between the observer and the light, the beautifuI tri-pinnate outline of the fronds becomes at once apparent. It is difficult to reproduce its peculiar woolly texture in an etching, so that it may be readily distinguished from the C. vestita; but its specific characters are sufficiently marked to enable almost any one to identify it. 
Plate XII.

\section{PELI乎A. Link.}

\section{Cliff-Brake Fern.}

Gen. Char.-Fruit-dots in elongated patches on the upper part of the reins; indusium membranaceous, continuous, formed of the reflexed margin; stipes dark colored.

This genus has a great resemblance to Pteris, and was formerly embraced in that genus. But it is evidently distinct. In the Pellæa the sporangia are arranged in elongated clusters at the ends of free veins. This is well exhibited in the young fertile frond; but, as the plant grows and reaches maturity, the clusters of sporangia are distributed in a linear order along the reflexed margin of the pimmule, forming a continuous line as in the genus Pteris. Near the apex of the leaflet it has a somewhat transparent, membranaceous border, which, toward the base, is folded over, and forms, with the re-curved margin of the pinnule, the covering or indusium.

This genus is sometimes confounded with Allosorus (Bernhardi), to which it is very nearly related. There are ten species in the United States, mostly found in the Pacific States and New Mexico; but one is indigenous to Kentucky.

I have attempted to show, in the magnified pinnule represented in the illustration, the characteristic nature of the veins and of the indusium. 
Plate XII.

PELLAA ATROPURPUREA, Link.

Cliff-Brake Fern.

The root-stock of this fern is tufted and surrounded with a number of chaffy scales. The stem is very black and polished, with a wiry appearance. The entire plant is stiff and coriaceous. The frond is pinnate, the pinnules of the sterle frond being more oval than those of the fertile, and somewhat heart-shaped at the base. The fertile frond is quite large, and in some situations attains the height of fifteen inches.

This fern is very properly called Cliff-Brake, as it is usually found in the crevices of dry cliffs. It is well distributed over the state of Kentucky, wherever there are limestone cliffs, though it is occasionally found in sandstone formations. It is very abundant on the sides of the cliffs bordering on Beargrass Creek in the neighborhood of Louisville, on the limestone cliffs of the Kentucky River (Short), and generally along the cliffs of the Ohio River. In some places the fronds do not decay during the winter, becoming brownish and curled up, and no longer performing the office of a leaf, after the growth of the new fronds takes place.

In cultivation it answers well for rock-work, but is not suitable for the Wardian case.

The Plate shows a plant of natural size. 








Plate XIII.

\section{ASPLENIUM. IInnæus.}

SPLEENIVORT.

Gen. Char.-Fruit-dots oblong or linear, oblique; indusium arising from the lateral veins, opening toward the mid-rib, sometimes double; veins free, simple, or forked.

The genus Asplenium is the type of the tribe Aspleniex, and is one of the largest of the whole family of ferns. Ten species are indigenous to Kentucky, and embrace all the species found in the Northern United States, except the somewhat doubtful A. ebenoides. Their habitat is as varied as their forms. They are found on mountain sides or in moist, open woods, on shaded cliffs, or in deep, rich valleys; some are very small, scarcely more than three or four inches in height; others attain the height of as many feet. The common name of the genus is Spleenwort, from its fancied virtue in curing diseases of the spleen.

The sori, or fruit-patches, are elongated or linear in form, arranged along the back of the frond somewhat obliquely to the mid-rib, and near the middle of the pinnule-never at its margin. In an examination of the Asplenium, the young student should procure a well-developed specimen, richly covered with fruit-patches; otherwise it will be difficult to determine the different species, especially the exotic.

The Plate will serve as a guide for all our native species; figure I represents pinnæ slightly magnified; figures 2 and 3, sporange and spore greatly magnified (Hooker and Bauer); figure 4, trichome or root-hair. The drawings of figures I and 4 were furnished by Prof. Hussey. The trichome (fig. 4) is not generic in character, but is found in some species. 









\section{PLATE XIV.}

\section{ASPLENIUM PINNATIFIDUM. Nuttall.}

This species is the most unattractive of the whole genus. The first and second pinnules of the fronds are sometimes pinnate, the entire frond is generally pinnatifid, the extremity slightly inclined to taper into a slender prolongation, somewhat similar to that of the Walking-leaf Fern, though not to such an extent. I have never found any plants of this species rooting at the apex, as in the case of the Walking-leaf. In some localities the fronds are very short and blunt, and quite unlike the normal type.

This fern seems to frequent the neighborhood of sandstone cliffs. It is quite plentiful in Rockcastle, Laurel (Miss Rule), Estill, Boone, and Grayson counties; at Rough Creek, Hardin County; in Edmonson and adjoining counties, distributed throughout the cliff-limestone regions of Kentucky, and in Carter County, in the northeastern part of the State (Hussey).

This fern can not be cultivated successfully in mounds, on rock-work, or in the Wardian case.

The Plate represents a plant of natural size. 







Plate XV.

\section{ASPLENIUIM BRADLEYI. D. C. Eaton.}

BRADLEy's SPLEENWORT.

This exceedingly rare fern has been found only in Tennessee and Kentucky, and was named in honor of Prof. F. H. Bradley, of the East Tennessee University, who discovered the plant originally on the top of Walden's Ridge in the Cumberland Mountains, near Coal Creek, East Tennessee, in 1872 .

To enable other botanists to recognize the more readily this rare little ferin, I will give Prof. Eaton's description of the species: "Mature plant 8-1o inches high; root-stock short, covered with narrow, acuminate fuscous-black scales; stipes tufted, slender, ebeneous, as in the lower half or two thirds of the rachis; fronds membranaceous, oblong-lanceolate, varying to linear oblong, the largest ones 5-7 inches long, and $\mathrm{I} / 2-2$ broad, pinnate; pinnæ rather numerous ( $8-12$ pairs), the lower ones more distant than the median ones, and of similar size, all short-stalked, oblong-ovate, obtuse or acutish, more or less incised, in the largest pinnatifid with oblong lobes which are toothed at the apex, in the smallest deltoid-ovate, slightly toothed; fruit-dots short, near the costules; indusium delicate. It differs from A. montanum in its larger size, more membranaceous texture, narrower outline of the fronds and shorter stalked pinnæ."*

Although I have collected in all the localities in this State where it is likely to be found, I have never met with it, and I am indebted to Prof. Hussey for the specimens from which my drawing has been made, and mainly for 
such information as we have of its growth in Kentucky. He found it in June, 1874 , in a single locality, near Bee Spring, Edmonson County, about twenty miles west of Mammoth Cave. He has given me the following description of this region: "All its water-courses, even the smallest wet-weather brooks and spring branches, take their rise between a series of steep cliffs, which form an elevated water-shed between Bear Creek and Nolin Creek, both tributaries of Green River, running in parallel courses, from five to ten miles apart, for a distance of twenty miles. This water-shed is intersected on either side by deep, highwalled ravines, whence gush forth cool springs, which either sink in the porous sandstone or murmur and plunge headlong to these rapid creeks. Under the overhanging sand-rocks, sheltered from the sun and sweeping winds, are sometimes spaces of vast extent, where the aborigines had their homes, as evinced by the numerous fragments of flints, and by the mortar holes in the detached masses of sand-rock. On one of these sandstone cliffs I found the Asplenium Bradleyi, and, recognizing it as new, I sent it to Dr. A. H. Curtiss, a botanical correspondent, from whom I learned that Prof. Eaton had already described it. On revisiting, in $\mathbf{1} 877$, the spot where it was found, very few fronds could be obtained, and care should be taken that it is not exterminated. I have searched a hundred similar localities without finding it. It was found along with the A. montanum and A. pinnatifidum, and not far from A. ebeneum. Under a moist, overhanging rock, a few hundred yards distant, was found the Trichomanes radicans, shut out from direct sunlight, and where there was constant dampness."

In the summer of $1876, \mathrm{Mr}$. C. C. Haskins, of New Albany, Ind., found a few fronds of this rare ferm in the 
neighborhood of Big Clifty, Grayson County.* He describes the locality as on the banks of Meeting Creek, where a huge bowlder of sandstone, thirty-five feet wide at the base and thirty feet high, had fallen from the cliff, presenting a northern exposure perfectly shaded from the sun. The fronds were detected, on his return home, among a large number of $\mathrm{A}$. pinnatifidum, which he had collected. The specimens were fully identified.

* See Bull. Torr. Bot. Club, vol, vi, p. 123. 







Plate XVI.

\section{ASPLENIUM TRICHOMANES. LInnæU.}

Common Maiden-hair Spleenwort.

The Maiden-hair Spleenwort, the common name generally given to it by the British botanists, has a very wide distribution, being found in all the temperate regions of the globe. Its habitat is generally on sandstone rocks, often associated with the A. pinnatifidum. Dr. Short found it in Kentucky on shady rocks; and Prof. Hussey says that "it grows in dense, green tufts, in moist situations, in the region which has the Mammoth Cave in its eastern part, and extends south, west, and north twenty or thirty milesa region abounding in steep and often overhanging cliffsin all, it may be a hundred miles in extent. Where the water drips from the rocks and constantly bedews the fronds it makes dense, roseate clusters, refreshingly green, and very attractive to the eye."

The fronds are simple, pinnate; the pinnules wedgeshaped, and crenate at the margin. The fibrous roots are so firmly imbedded in the soil of the crevices and interstices of the rocks that it is difficult to secure good specimens.

Mr. Redfield refers this plant to his Cosmopolitan division. It is a little beauty, and a great favorite among fern fanciers. It dries well, and its delicate fronds are very suitable for decorative purposes. It is easily cultivated, especially in the Wardian case.

The Plate represents the plant of the natural size, but specimens six inches in length have often been found. 





d.

- 1 . से

Plate XVII.

\section{ASPLENIUM EBENEUM. Aiton.}

\section{Ebony SpleENWORT.}

The Ebony Spleenwort has some resemblance to A. Trichomanes, especially when the fronds are young; but the species is well marked. It is pinnate, lance-linear in form, often eighteen inches in height, with pinnæ over an inch in length, the upper side triangular-lobed or somewhat halfhalbert shaped. The fern varies very much both in size and general appearance. The etching aims to show several different kinds of fronds, the youngest, the more advanced, and the oldest, the latter with well-marked fruit-dots. The mature fronds are generally more contracted than those of a younger growth.

The A. ebeneum is very common in all our Kentucky woods, especially on out-cropping rocks, and about the roots of beech-trees. It is found particularly on argillaceous hillsides (Riddell), preferring rich rocky woods, and common where there are no rocks on the surface (Hussey). It is so frequently met with that it is needless to give localities. It is very suitable for cultivation, either on rockwork or in the Wardian case. 









\section{Plate XVIII.}

\section{ASPLENIUM MONTANUM. Will.}

\section{Mountain Spleenwort.}

The Mountain Spleenwort has the same habitat as the Maiden-hair Spleenwort and the Pinnatifid Spleenwort, and is usually found associated with them. It is quite common in Kentucky, especially in the mountain regions, though my best specimens were obtained at Big Clifty, Grayson County. A single plant had more than fifty fronds, each six or seven inches long; and Prof. Hussey, formerly of the Kentucky Geological Survey, has specimens in his collection over ten inches in length. Specimens are frequently found with the fronds bifurcating toward the apex, but only in thrifty plants. The roots are fibrous, penetrating the crevices of the rocks, as those of the A. Trichomanes.

The Plate represents a plant of average size, the tallest frond to the right showing a slight attempt at bifurcation. 




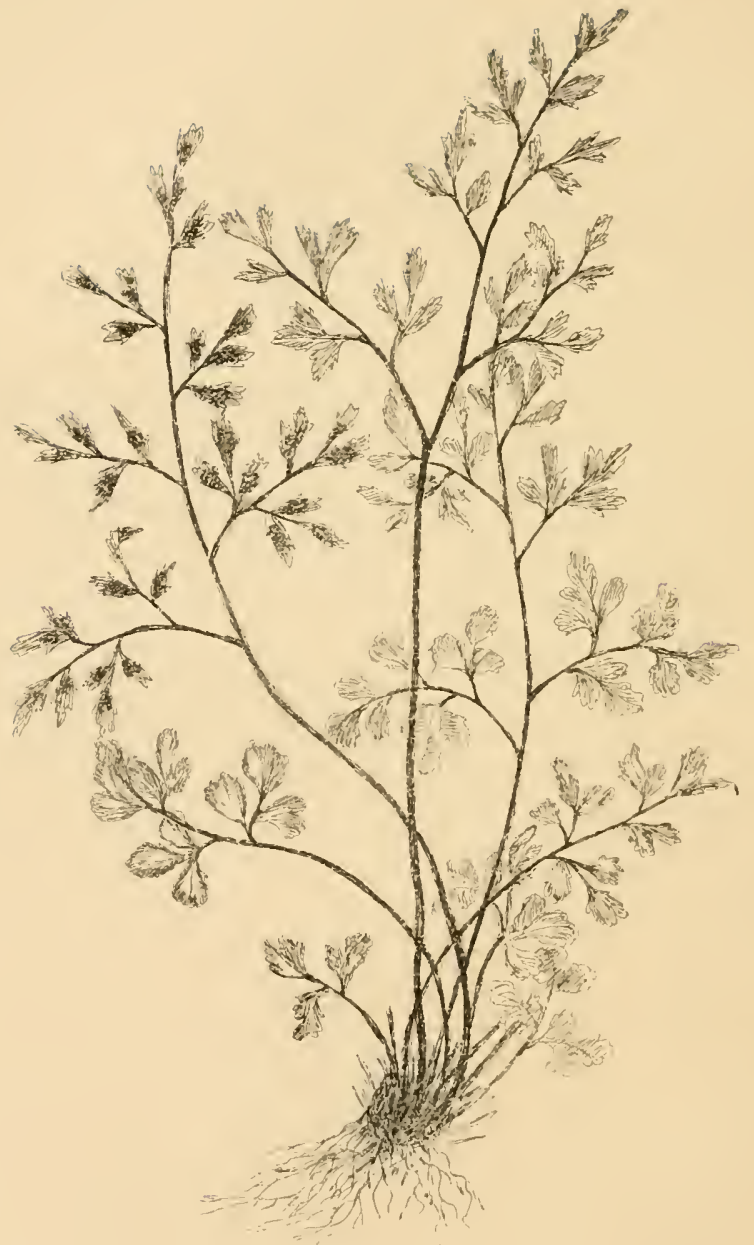


Plate XIX.

\section{ASPLENIUM RUTA-MURARIA. Linnæus.}

\section{WALL-RUE SPLEENWORT.}

This species, named from its resemblance to the common garden Rue, is the smallest of the Aspleniums in this country, the average size being scarcely three inches in height. In sheltered locations it sometimes approaches five inches. It is generally found on exposed limestone rocks, selecting for its habitat the smallest holes and chinks to be found. It is much more difficult to get it out of its hiding place than any fern yet described. It is very hardy, remaining green all winter, even in exposed situations. It is very rare.in Kentucky. Dr. Short found it on the cliffs of Kentucky River. I have found it at Rock Springs, Oldham County.

This little fern is not a very attractive-looking plant, and is very apt to be ignored by ordinary fern-gatherers. In Europe it is widely distributed, generally growing on old bridges, or on the ruins of old abbeys and castles.

The fronds are bi-pinnate; the pinnæ wedge-shaped, often toothed at the apex. In the fully-developed plant the fruit-dots are so close together that they generally form an elongated brown patch. 










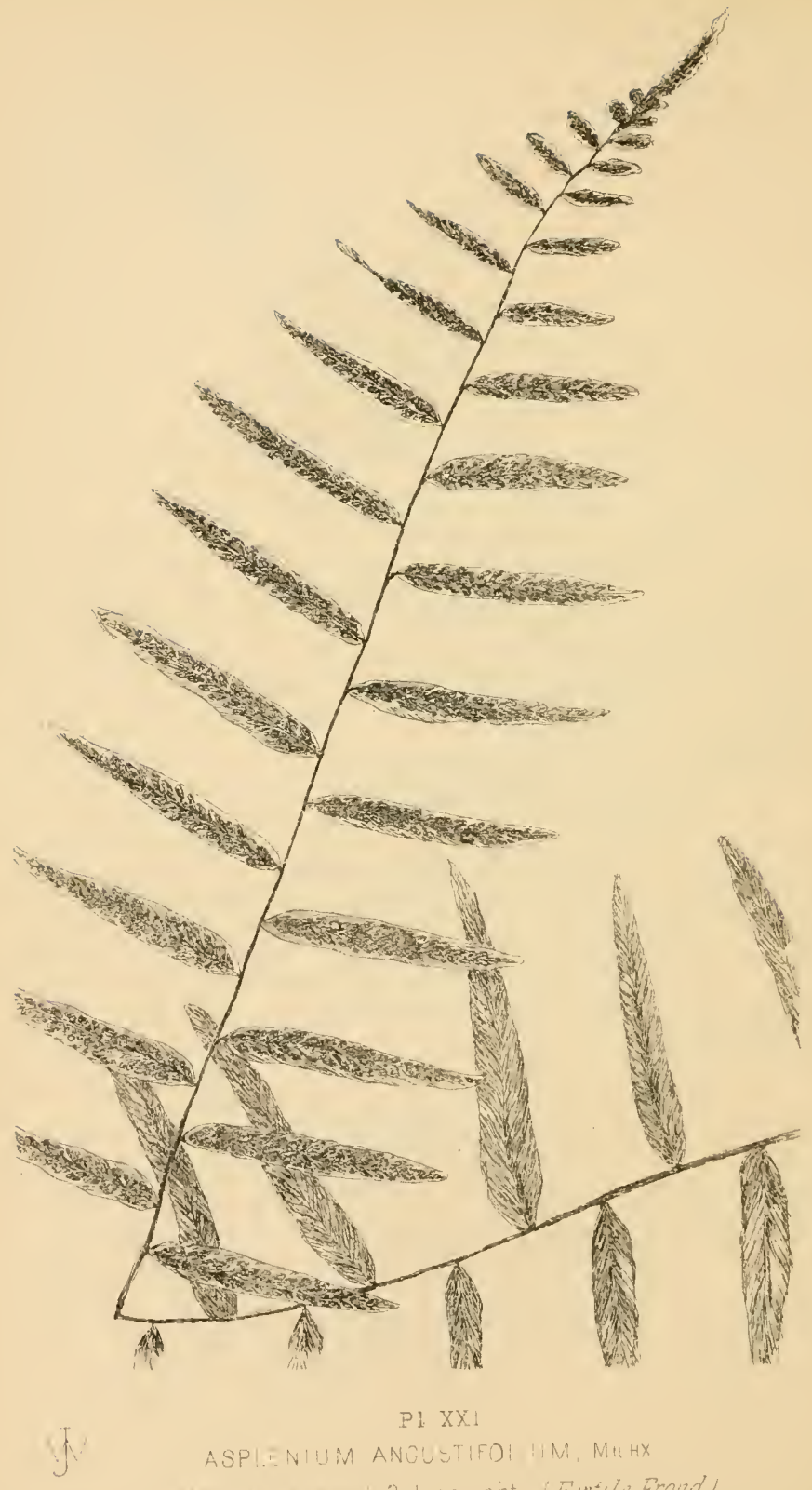




\section{Plates XX AND XXI.}

\section{ASPLENIUM ANGUSTIFOLIUM. Michx.}

Narrow-leaved Spleenwort.

This fern differs from any of the Aspleniums yet described, both in general appearance and habitat. It loves the damp, rich soil of deeply shaded woods, and has for its companions the true Maiden-hair Fern, the Beech Fern, and the Lady Fern. It is a tall and graceful plant, often growing four feet in height. It has two kinds of fronds, the sterile and fertile. The sterile frond (Plate XX) is pinnate with lanceolate pinnæ, broad at the base. It is very soft and delicate, and when fully grown is about two feet high. The fertile frond (Plate XXI) comes up much later, and is also pinnate, the pinnæe contracted and narrow, the upper side being somewhat ribbed, and the lower profusely covered with fruit-patches arranged in pairs on each side of the mid-vein. The frond is tall and linear, having the appearance of a willow wand. The two illustrations show the fronds cut off near the point, and are sufficient to enable the young student to determine the plant.

The Narrow-leaved Spleenwort is a very tender fern, nipped by the first frosts. In July and August it is most luxuriant; accordingly, it is sometimes called the Summer Fern. It is very common in all our damp, rich woods. It grows quite readily on sheltered mounds with plenty of rich soil. 


b

ㄴ.



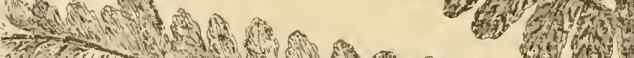
3.

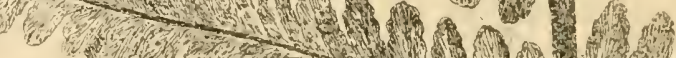



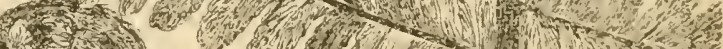

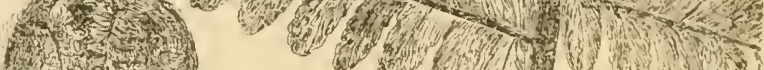

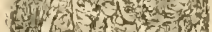

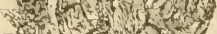

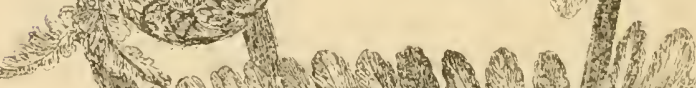

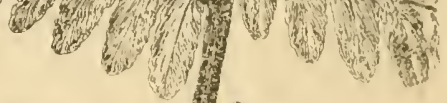

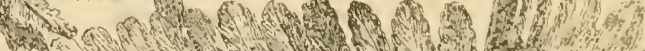

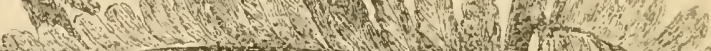

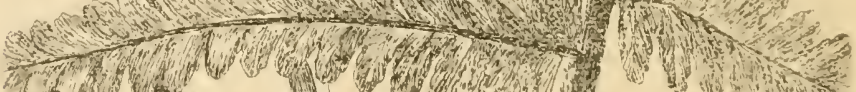

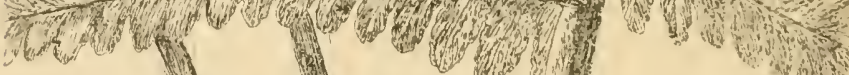

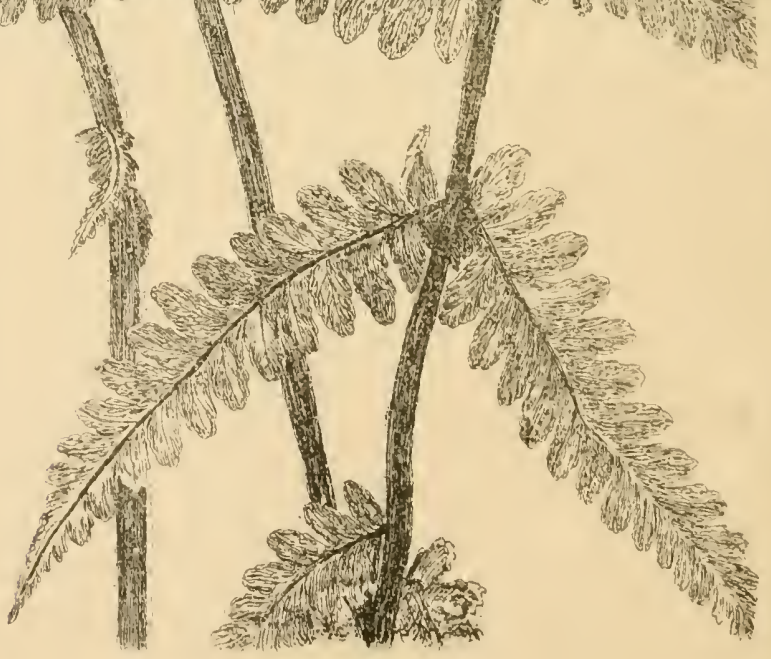

P. XXIT 
Plate XXil.

\section{ASPLENIUM THELYPTEROIDES. MichX.}

This fern is also tall and graceful, with the same habitat as the $\mathrm{A}$. angustifolium, and is often found along with it. The fronds are pinnate, the pinnæ deeply pinnatifid. The fruit-patches are arranged on the back of all the fronds, in pairs, on each side of the mid-vein. It is, likewise, very tender, though apparently more hardy than the Narrowleaved Spleenwort. However, it dies early in autumn. It is very common in all our rich woods, on the shady banks of streams, and loves plenty of moisture. It can be easily cultivated if placed in the proper soil.

This stately fern presents a very striking and elegant appearance as it unfolds its large, downy fronds, and, in strong contrast with some of the diminutive forms of this genus, develops into a plant of graceful beauty. Figure 2, showing the uncurling of the frond, was sketched from the living plant. I have tried to represent the succession of the leaflets still folded up in the head. 'Though it appears to be hardy, its texture is quite soft and delicate. It grows well in shaded mounds, but is too large for the ordinary Wardian case. 




\section{P}

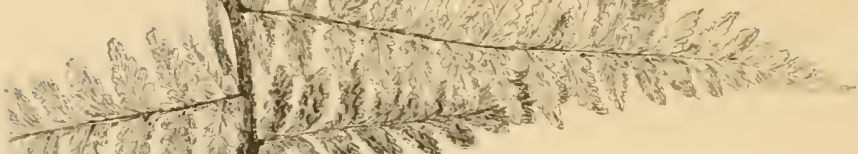

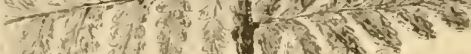

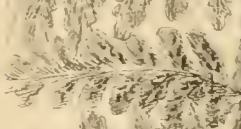

1. 2 ,

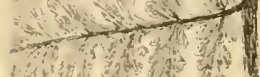

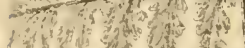

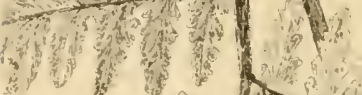

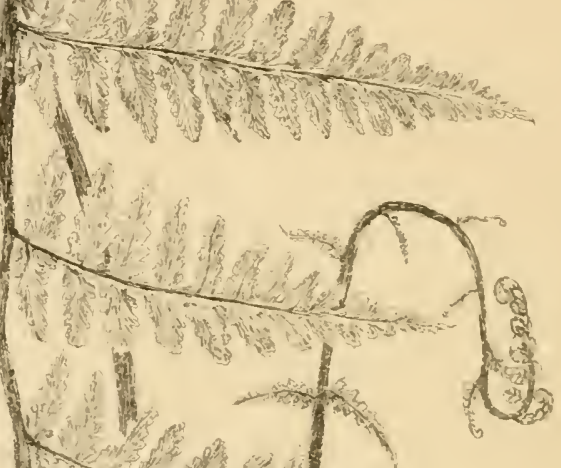

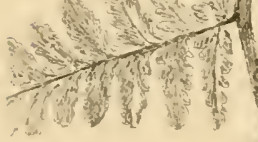
(i) a
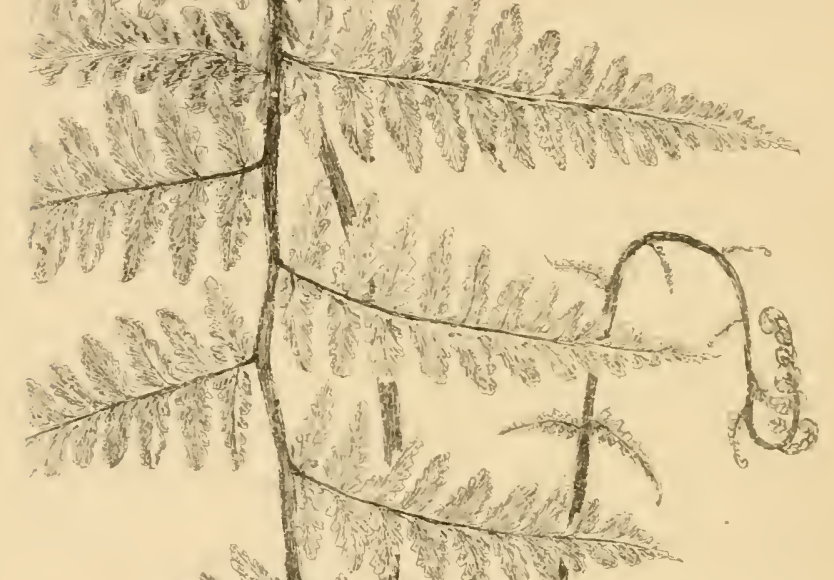





\section{ASPLENIUM FILIX-FGMINA. Bernh.}

\section{LADY FERN.}

Some authors do not consider the Lady Fern as a true Asplenium, since the fruit-dots, instead of being linear, are half-moon shaped. It is the Athyrium of some, and by others it is referred to the genus Aspidium. The drawing is from a young frond, and represents the pinnæ rather wide apart; but it would require a much larger plate to show this lovely plant as it really appears. It is very graceful in outline, and possesses an exceedingly delicate green tint. The Lady Fern is by no means uncommon in Kentucky, having been collected by myself in many localities, and by Dr. Short on the low grounds along the Red River, and at Crab Orchard, Lincoln County.

This is the favorite fern of the poets. Sir Walter Scott thus alludes to it:

"Where the copse-wood is the greenest,

Where the fountain glistens sheenest,

Where the morning dew lies longest,

There the Lady Fern grows strongest."

The following description of this graceful fern, which applies as well to the species in this country, is taken from Moore's "Popular British Ferns:"

"The Lady Fern claims precedence over every other British species on account of the exquisite grace of its habit of growth, the elegance of its form, and the delicacy of its hue. The habit of the plant is tufted, the caudex of the larger varieties often with age acquiring some height, and elevating the circle of fronds on a low, rude pedestal; this stem, however, never acquires more than a 
few inches in length. In winter the summit of this stem is occupied by a mass of incipient fronds, each rolled up separately and nestling in a bed of chaffy scales. In May or June these fronds become developed, a score or upward being usually produced. They reach maturity early in summer, during which time a few additional fronds are generally developed from the center. The form of the frond is lanceolate, more or less broad; and they are supported on stipeles, which are scaly at the base, and usually about a third of the entire length of the fronds. The division of the fronds is bi-pinnate, pinnæ lanceolate, drawn out at the point, the pinnules more or less lobed or pinnatifid. The delicate texture of the frond renders the venation very distinct." *

This fern is very common in Kentucky. I have found the best specimens in Bullitt County, in deep ravines, at the base of the knobs. It is apt to vary considerably, sometimes bifurcating at the apex of the frond, and sometimes with a dark, almost purple stem, and is generally showy. Young collectors are inclined to confound this plant with other species, but the slightly-curved fruitpatches will readily distinguish it.

* Moore's History of British Ferns, 3d ed., p. 123. 


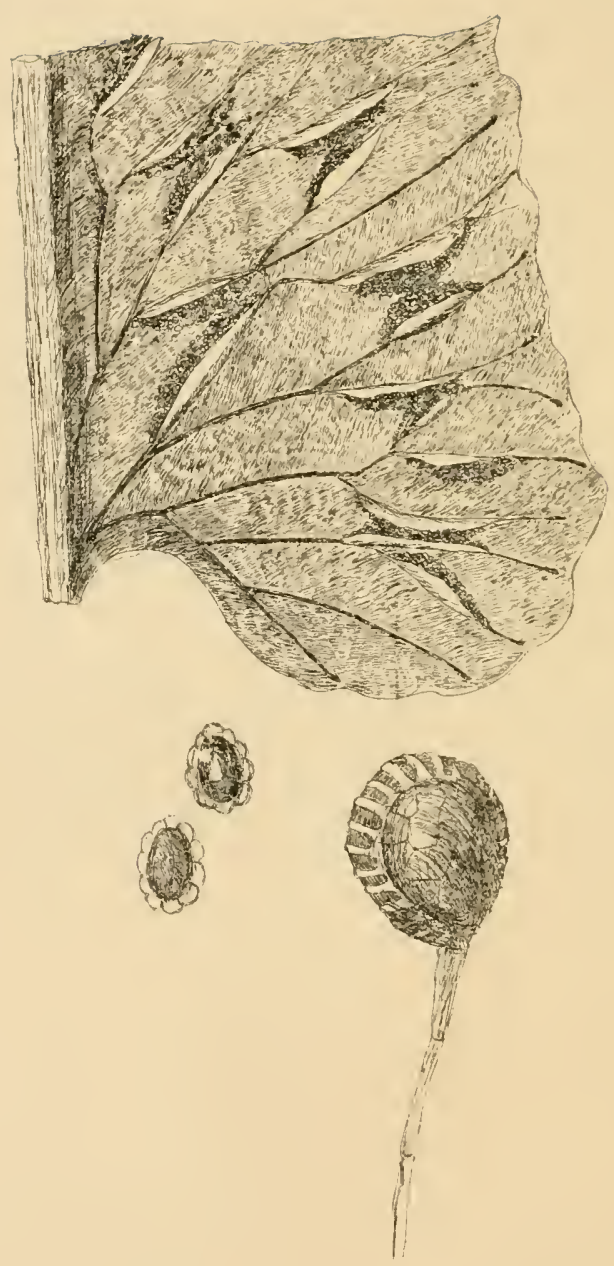


\section{Plate XXIV.}

\section{CAMPTOSORUS. Link.}

Gen. Char.-Fruit-dots oblong or linear, single or in pairs, irregularly scattered; indusium attached by one side to the lateral veins; veins reticulated.

This is a very small genus of the group Asplenieæ, consisting only of two species-one found but rarely in Siberia, the other in the United States. The Siberian species, as well as that indigenous to this country, has the peculiarity of rooting at the apex, as shown in Plate XXV. The fruit-patches are oblong or linear; the veins reticulated, not free, as in most ferns. The sori are covered with a linear indusium, usually connivent or joined together in irregular unequal pairs, but sometimes scattered over the surface on account of the irregularity of the venation.

The illustration shows part of the lower half of a frond, magnified several times, and also represents the sporange, with two spores highly magnified. All the figures given in the Plate are from Hooker and Bauer. The irregular arrangement of the sori and the peculiar character of the veins are brought out prominently, as these are significant points. 






$V$

$1 \quad x \wedge$. 


\section{Plate XXV.}

\section{CAMPTOSORUS RHIZOPHYLLUS. Link.}

\section{WALKING-LEAF FERN.}

The first impression of the amateur botanist on seeing this plant would scarcely lead him to believe that it is a fern at all. It does not have the appearance of a fern; but an examination of the fruit-patches and other peculiar features of the fern tribe will soon set him right. The veins of the leaf are somewhat different from most ferns, but still retain their general characteristics. It has a simple frond, auricled at the base. The auricles are sometimes quite long. The frond possesses the peculiarity of rooting at the apex. Tapering into a long, narrow prolongation, it bends down among the mosses, and very often takes root. Two and three generations are often found springing from the parent plant. The Asplenium pinnatifidum has sometimes a slender prolongation, and has even been reported as rooting at the point; but this peculiar mode of growth in the Asplenium lacks verification. The Walking-leaf bears some resemblance to the Hart-tongue Fern (Scolopendrium), but the leaves of the latter have free veins, and are blunt at their apices. The Walking-leaf Fern is an evergreen, and the best specimens are often collected in the winter. It is found in all our Kentucky woods whereever there are detached, moss-covered bowlders, on outcropping rocks and cliffs, either limestone or sandstone. It has about the same habitat as the Asplenium ebeneum.

This plant is well named on account of its singular mode of attachment to the soil. It is of easy cultivation, either in mounds or in the Wardian case, and is especially suitable for rock-work. 









\section{Plate XXVI.}

\section{PHEGOPTERIS. Fée.}

GEN. ChaR. - Fruit-dots naked on the back of the veins near the apex; stipe continuous with the root-stock, not articulated with it ; fronds ternate or twice pinnatifid.

This genus has given rise to much discussion among pteriologists, or fern specialists. Formerly it was included in the tribe Polypodieæ, and was considered a true Polypody, including the P. hexagonopterum of Michaux, which bid fair to be one of the very few ferns found by that enterprising naturalist, whose name should survive the constant changes of the nomenclature. The fruit-dots were destitute of indusia, as in the Polypodium; but the general appearance of the plant, the character of the veins, and the position of the sori were quite different from the latter. Prof. Sachs places this genus in the tribe Aspidieæ, where it would seem to properly belong. Prof. D. C. Eaton, in the last edition of Gray's Manual, has also included this genus in the tribe Aspidiex. In a letter to the author this distinguished pteriologist remarks: "Phegopteris is capable of being defined in nearly the same words as Polypodium, but it really has nothing to do with it. But it is so closely connected with Aspidium that there is hardly any clear distinction between the two. The mode of growth from the root-stock is precisely the same; the position of the fruit-dots on the back of the vein, not at the tip or on the point of union of several veins, is the same in both; and the general shape and branching of the fronds are very much alike in the two. As to the presence or absence of indusium, the fact is that many species have been said by some authors to have no indusium, and other authors will find 
indusia after all. Then, in many Aspidiums the indusium is so small and delicate that it is hard to find even on living plants. On the whole, there is an unmistakable passage from Phegopteris into Aspidium. Some German writers even insist that the two are but one natural genus."

Figure I represents a pinnule slightly magnified; figure 2, a lobe greatly magnified, showing the situation of the sporangia and the structure of the tissue. 



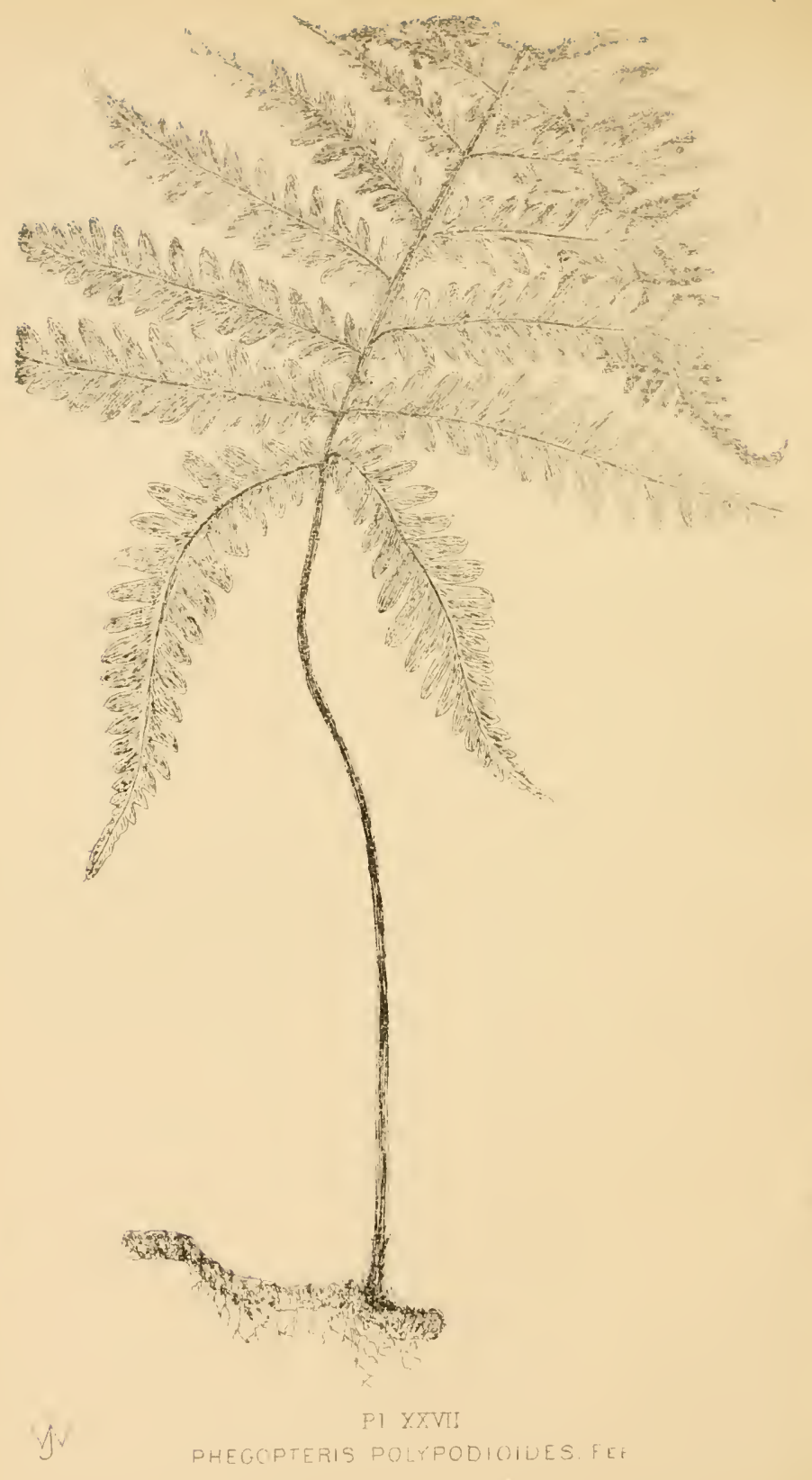


PLATE XXVII.

\section{PHEGOPTERIS POLYPODIOIDES. Fée.}

BEECH FERN.

The Beech Fern is the most easily recognized of all our common ferns. The root-stock is a slender, creeping stem, sending up, in early summer, a frond about eighteen inches in length, including the stipes. The frond is triangular in outline, and longer than broad, with the two lower pinnæ reflexed and pointing forward. It has a somewhat chaffy and downy stalk. It grows luxuriantly in all our damp, rich woods, its root-stocks trailing under the moss, as in the Common Polypody, or penetrating the leaf-mold to the depth of a few inches. The fern is difficult to lift, particularly for transplanting, since the stems are brittle and easily broken; but by taking care to get plenty of soil, the plant may be moved, and when once settled in its new home it grows exceedingly well. It is readily dried, the fronds being very thin, and, if carefully preserved, they make very handsome specimens, either for the herbarium or for decorative purposes.

The Beech Fern is the Polypodium Phegopteris of Linnæus, and of the older botanists; but the reason of its removal to a new genus will be apparent from the generic description. The plant in the illustration is of natural size, though often found much larger. A root-stock of Polypodium is given in Plate $\mathrm{V}$, showing the characteristic difference between that genus and Phegopteris, where it will be observed that the stipe is articulated with the rootstock, and not continuous with it, as in the species belonging to the genus under consideration. 
In many respeets this fern resembles so closely the other species found in Kentucky, that it may be even questionable whether they are really distinct. The rich soil of this region, together with climatic influences, may serve to produce a larger and stronger form in the $\mathrm{P}$. hexagonoptera. There seems to be, however, this distinction - the divisions of the lower pinnæ in the latter are elongated and pinnately lobed, while in the P. polypodioides they are oblong, obtuse, and entire. I have represented the two species as accurately as possible; and the attention of students is called to this similarity in the two forms in the hope that careful observations in future may settle the question beyond a doubt. 








\section{Plate XXVIII.}

\section{PHEGOPTERIS HEXAGONOPTERA. Fée.}

The general appearance of this fern is very similar to the one last described, except that the triangular frond is broader than long, the two lower pinnæ at right angles to the rachis, but not reflexed as in P. polypodioides. The main rachis is irregularly winged, as shown in the Plate. When fully grown the fronds are from seven to twelve inches broad. Is quite common in our Kentucky woods, and is often met with more frequently than the other species. Its general habitat is doubtless more southward, but it loves the same rich, open woods, and possesses all the characteristics of the Beech Fern.

This is the Polypodium hexagonopterum of Michaux and Willdenow; * and, in the earlier editions of Gray's Manual, it was included among the true Polypodys. It furnishes a beautiful object for the microscope. It is easily decolorized; and, the tissue of the leaf being very thin, its reticulated structure is readily seen. Plate XXVI, figure 2 shows a small portion of the frond of this fern highly magnified, bringing out the fine, glandular hairs, with the sorus situated upon the back of the vein. It is a very good object for double-staining-a process well known to microscopists.

* See Willd. Sp. P1. V, p. 200, and Michx. Flor. Bor. Am. II, p. 27 I. 




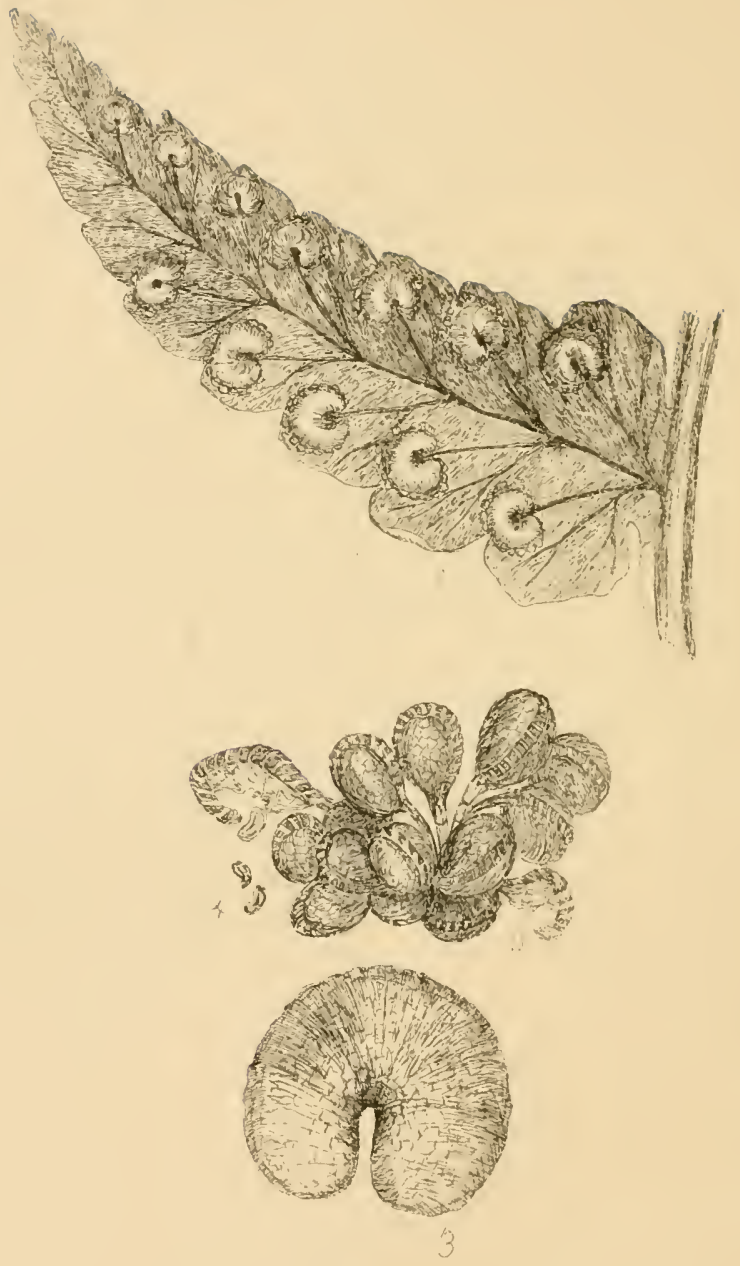


Plate XXIX.

\section{A S PIDIUM. Swartz.}

S H I E LD FE R N

Gen. Char.-Fruit-dots roundish, scattered on the back of the frond; indusium attached above the sori, round or kidney-shaped; veins free, simple, or forked; stipes not articulated with the rootstock.

Aspidium is one of the largest genera of ferns, and is the typical genus of the tribe Aspidia. Eighteen species are given by $\mathrm{Mr}$. Redfield in his "Geographical Distribution of the Ferns of North America," without including the six varieties enumerated by John Robinson in his excellent "Check List of the Ferns of North America, north of Mexico." Of these seven are indigenous to Kentucky, so far as I have been able to discover, though it is quite possible that the number may be increased.

The form of the fruit-dots and their covering (indusium) is the principal characteristic of this genus. The indusium is flat, round, or somewhat kidney-shaped, resembling a shield, whence the name of Shield Fern (Plate XXIX, figure 2). This shield, in some species, is quite orbicular, and fixed at the center. Figure 3 shows a number of sporangia; some bursting their elastic rings. Most of the members of the genus are strong-growing, pinnate ferns. The Plate represents the Aspidium marginale, a very common, but tall and beautiful plant. 

Plate XXX.

\section{ASPIDIUM THELYPTERIS. Swartz.}

\section{MARSh Shield FERn.}

The usual habitat of this fern is in swamps and boggy marshes, choosing for its companions the Sensitive Fern, the Osmundas, and the cryptogamic and flowering plants peculiar to marshy ground, such as the Sagittaria, Lizard's Tail, Cat-tail Flag, Equisetum, etc. The plant has a beautiful fresh green color, the dark green of the upper side of the fronds contrasting very strongly with the light green of the back, occasioned by the profusion of light-colored fruit-patches. It comes to maturity about the latter part of July or the first of August. The frond is pinnate-lanceolate, pinnæ deeply pinnatifid; the margins of the lobes are revolute.

It is not very common in Kentucky. The best specimens I have obtained were from a marsh near Prospect, on the Narrow Gauge Railroad, about ten miles from Louisville. The Plate represents a piece of a frond natural size. 



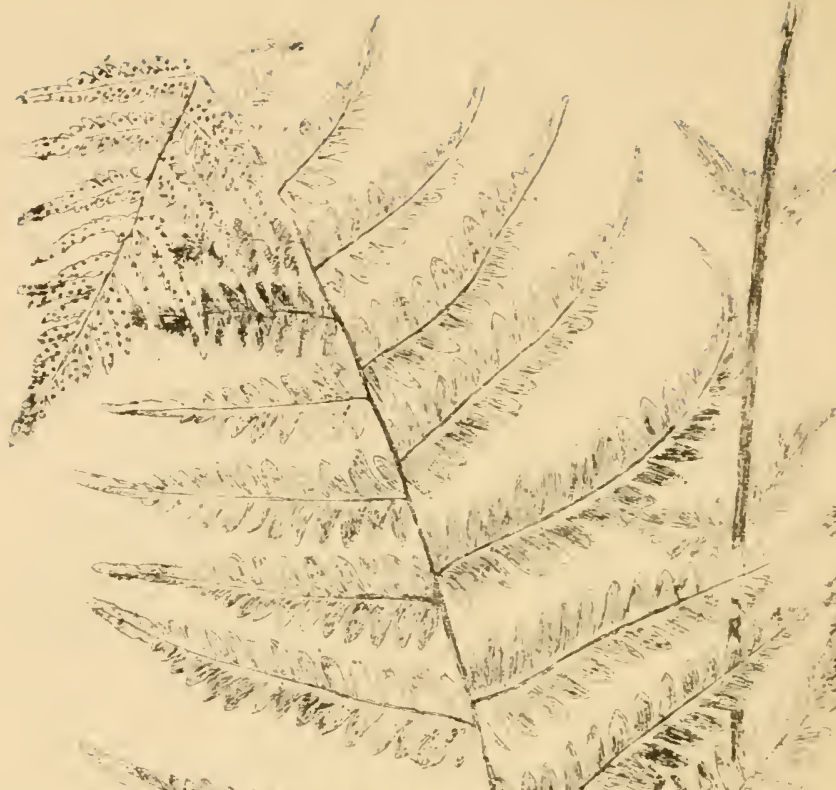

$\div$



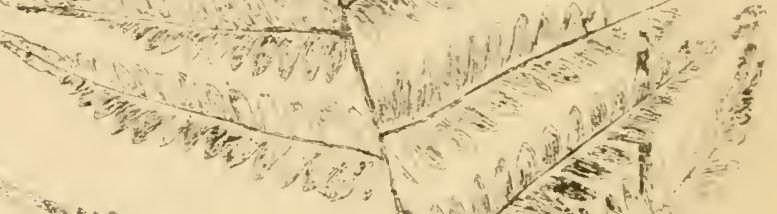





PI XYY.

ASP. L Y NOVEBSRACLNSE SYAR- 


\section{Plate XXXI.}

\section{ASPIDIUM NOVEBORACENSE. Swartz.}

NEW YORK SHIELd FERN.

'This fern is even more delicate than the A. thelypteris. The length of the frond from the root-stock averages about fifteen inches. It is pinnate, lanceolate in outline, but tapering both ways from a point a little below the middle. The pinnæe are lanceolate, tapering to a point; the lobes of the pinnæ less blunt than those of the Marsh Shield Fern. The color of the fronds is a pale green, and is the same on both sides. The indusium is very minute, and, except in young plants is not easily seen. It is not very common in Kentucky, but grows luxuriantly about Livingston, Rockcastle County.

It is one of the most difficult ferns which I have attempted to draw, on account of its similarity to the Marsh Shield Fern, just described. The outline of the two ferns, especially that of the pinnæ and lobes, is exactly alike in both. In the illustration I have tried to give the whole plant, showing how the pinna taper toward the base. The greatest difference, however, between the two ferns lies in the character and arrangement of the fruit-dots, and in the texture of the tissue of the fronds. The New York Shield Fern is very delicate and tender; indeed almost transparent, with the fruit-dots near the margin of the pinnule, in separate round patches; the Marsh Shield Fern is rather coarse looking, with a great profusion of sori situated in close, round patches, forming, when ripe, a continuous line. The margin of the pinnule is slightly reflexed, not forming, however, an indusium, as in Pteris and Pellæa, but is simply recurved. 






V 
Plate XXXil.

\section{ASPIDIUM SPINULOSUM. V. Intermedium. Willd.}

Spring Shield Fern.

Of the three varieties of A. spinulosum, this is the only one which I have found in Kentucky. It is the A. intermedium of Willdenow, not of Muhlenberg, the fern described by the latter being the A. spinulosum, which I have not been able to find in this State, though Riddell attributes it to the low, damp forests of Central and Northeastern Ohio.* The variety intermedium, however, is by no means uncommon in Kentucky, though I have seldom found it in Jefferson, Oldham, or Bullitt counties; but it grows in the greatest perfection at Big Clifty, Grayson County, as well as in Laurel, Rockcastle, Edmonson and Hardin counties.

It is a very graceful fern, which collectors may readily mistake for the Lady Fern, but the round fruit-dots, the minute spiny teeth of the lobes, and the coarseness of its general appearance will serve to distinguish it from the

: See Synopsis of the Flora of the Western States, by John L. Riddell, A. M., Cincinnati, I835, p. I06; also Supplementary Catalogue of Ohio Plants, Cincinnati, I $\$ 36$, p. 2 I. It is difficult to determine with certainty, from his descriptions, whether the latter of the two ferns described by Riddell is identical with our var. intermedium, Willdenow (Eaton?); but the forms are so variable that it may be questionable whether the $\mathrm{A}$. spinulosum should be dignified with any varieties whatever, the Swartzian species being sufficiently comprehensive to include all its variations. From a careful comparison of the Kentucky specimens, which seem to belong to the var. intermedium, with Hooker's typical A. spinulosum, kindly sent me by Mr. Davenport, I am convinced that the differentiation is so variable, the forms passing so imperceptibly into each other, that no particular type can be said to be wholly persistent. On this point see Hooker and Arnott's British Flora, p. 570, note. 
latter. With their finely-dissected lobes the fronds are exceedingly elegant, and render it specially desirable for interior decoration. They are about two feet and a half high, oblong - ovate, twice pinnate, with pinnatifid pinnules. The lobes are furnished with very small spinous teeth, which are much more marked in some plants than in others. The base of the stipe is covered with a number of large, membranaceous, dark brown scales.

The Plate represents a small frond of full size; the spiny tooth is scarcely definite enough. 


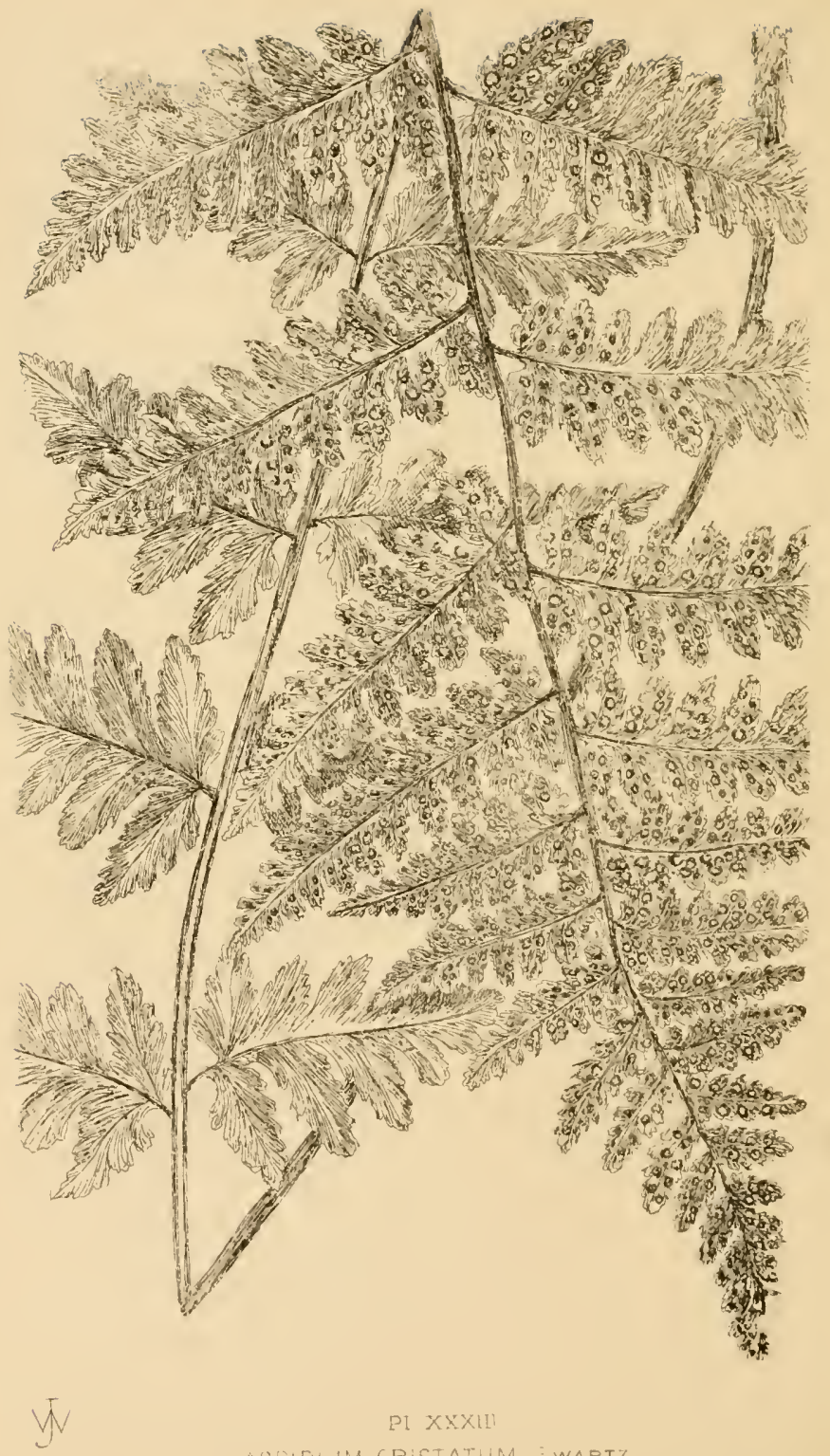


Plate XXXIII.

\section{ASPIDIUM CRISTATUM. Swartz.}

CRESTED SHIELD FER N.

This is a tall fern with somewhat linear or lanceolate fronds, often two and a half feet high, pinnate, with slightly stalked pinnæe, triangular-ovate, and deeply pinnatifid, the lobes serrate or finely toothed. The short triangular pinnæe and the well defined fruit-dots, arranged in two rows on the lobes, distinguish it at once from all other Shield Ferns. Hooker remarks that its outline is quite distinct from that of the A. spinulosum, in being narrowed below. It seems to be rare, even in Europe, where it is found on boggy heaths.

Riddell has stated that it is common in Central Ohio, without attributing it to Kentucky, from which it may be inferred that Dr. Short had not found it in this State; indeed, the latter makes no mention of it in any of his published catalogues of Kentucky plants. From my own experience in collecting, I should consider it much less common than the other Shield Ferns which I have described. I have never met with it, but it will doubtless be found in swampy localities in the mountain counties. It was found by Miss Rule near Rockcastle Springs, Laurel County ; * but Prof. Hussey, who botanized very thoroughly over Edmonson and adjoining counties, was not able to discover it in that region.

The Plate shows a small frond natural size.

*2 See Bot. Gazette, vol. ii. p. 62. 






a 19





$\rightarrow a, 190=$

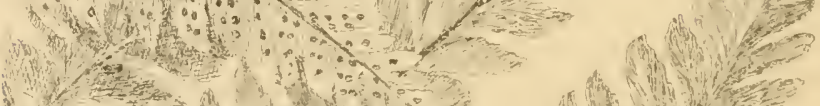

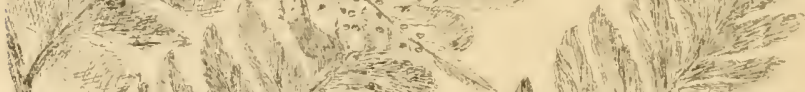

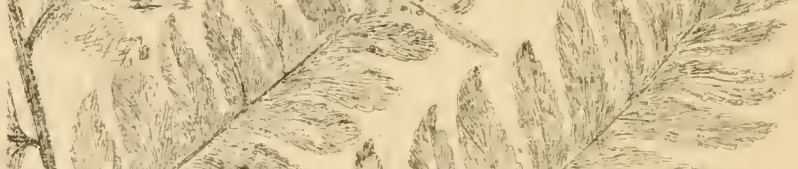

,





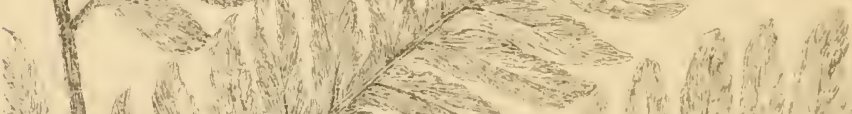




(1)















\section{Plate XXXIV.}

\section{ASPIDIUM GOLDIANUM. Hook.}

Goldie's Shield Fern.

This is the largest and handsomest of all the Shield Ferns in this country, being frequently more than three feet in height, with broadly ovate pinnate fronds; the pinnæ alternate, stalked, oblong-lanceolate, with lobes deeply cut, wavy, crenate. The pinnæ at the broadest part of the frond are about six and a half inches long and one and a half inches wide. The somewhat scythe-shaped lobes bear about eight pairs of fruit-dots, which are very distinct and well defined, and furnish beautiful examples of the characteristic fruit-dots of the genus.

Although it may be considered a somewhat rare fern in the less elevated portions of the State, it is not uncommon among the mountains, where altitude makes amends for the lack of a higher latitude, more suitable to its growth. I have found it in great abundance near the Little Rockcastle River, in Laurel County.

The illustration gives a few of the pinnæ, natural size; it conveys, however, at best but a very imperfect idea of this splendid fern. 







Plate XXXV.

\section{ASPIDIUIM MARGINALE. Swartz.}

\section{Marginal Shield Fern.}

This is a beautiful fern, and serves better than any other to show the true characters of the genus. The fronds are about two feet long, pinnate, ovate-oblong; the pinnæ lanceolate, slightly curved toward the apex. The fruit-dots are readily observed by means of a pocket lens. They are placed near the margin of the pinnule, and are beautiful objects for close examination with the microscope. The plant is evergreen, rather coarse in texture, the upper side of the frond dark green, the under a very pale green. It is not a common fern in Kentucky, though it is very abundant in Rockcastle County, and doubtless in other mountain counties of the State.

On account of its large size it can only be readily cultivated in the open air, and not in the Wardian case. The Plate is too small to give any thing more than a general idea of this elegant representative of the fern tribe. 




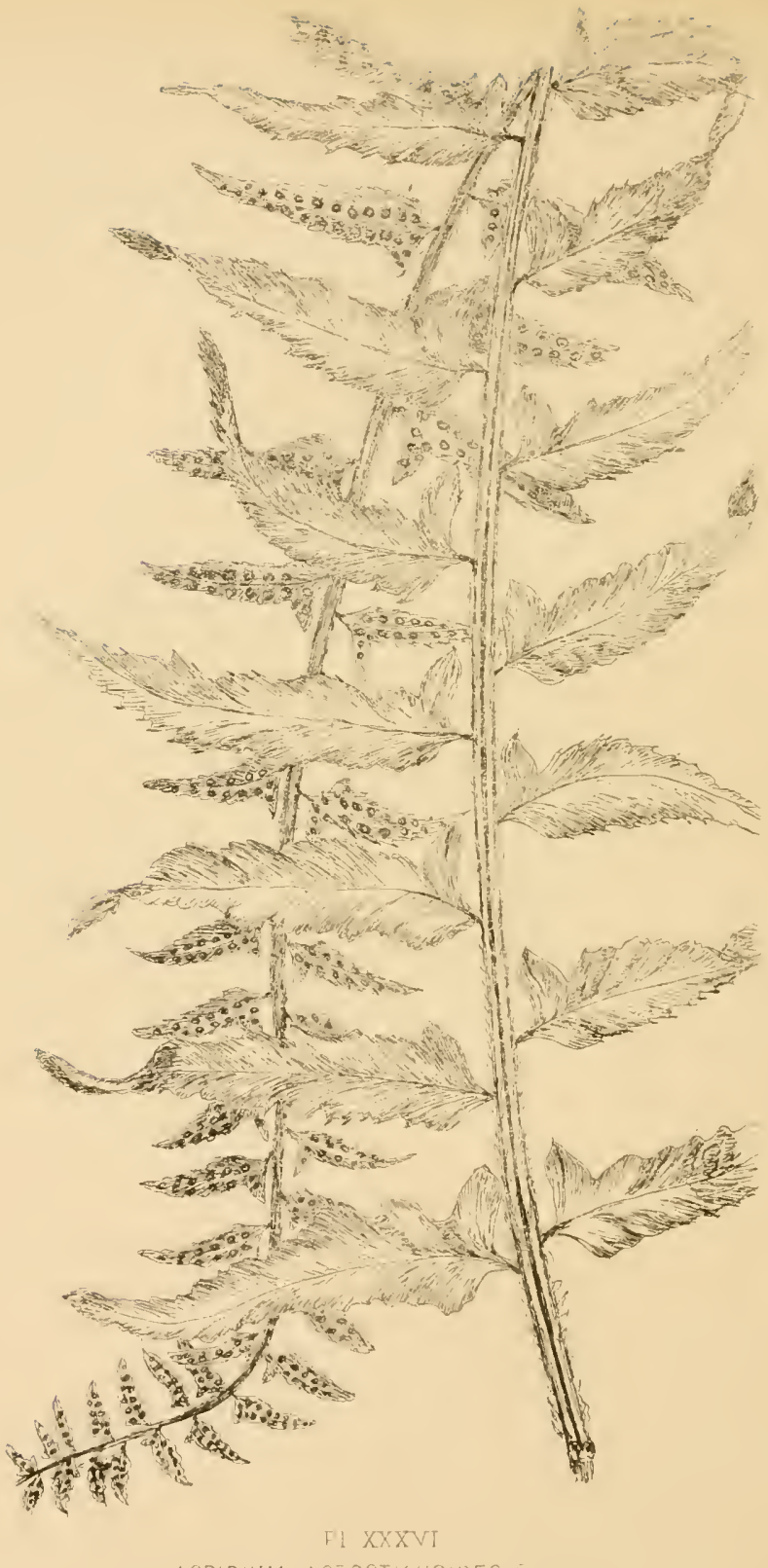

ASPIDUUM ACFOSTICHOIDES, SWAITZ 


\section{Plate XXXVI.}

\section{ASPIDIUM ACROSTICHOIDES. Swartz.}

\section{Winter Fern-Christmas Fern.}

This is undoubtedly the most commonly met with of all the Shield Ferns. In fact it is the best known of our native ferns, growing every where without any special habitat. The best specimens have usually been obtained, however, along the banks of streams. It is found as well in exposed situations upon high rocks, as in ravines or deeplyshaded woods.

The average size of the plant is about twenty inches, but some attain a height of over two feet. It has a strong, tufted root-stock; the stipe covered very profusely with membranaceous, chaffy scales; the frond lanceolate, pinnate; the pinnæ lanceolate, with a well-marked triangular lobe on the upper side. The frond becomes very narrow and contracted toward the apex, probably on account of the pabulum supplied to the leaf being used up in fruitpatches, which cover the entire surface of this constricted portion. The plant is very variable, being sometimes broad and foliate, when the fronds are generally sterile, and not so strongly marked with spines. The fertile fronds are much narrower than the sterile, the pinnæ becoming crisp and wavy. The Plate represents the frond near the middle, with the point bent, showing the fructification beneath.

This fern is very hardy, and is consequently very suitable for out-door cultivation. 




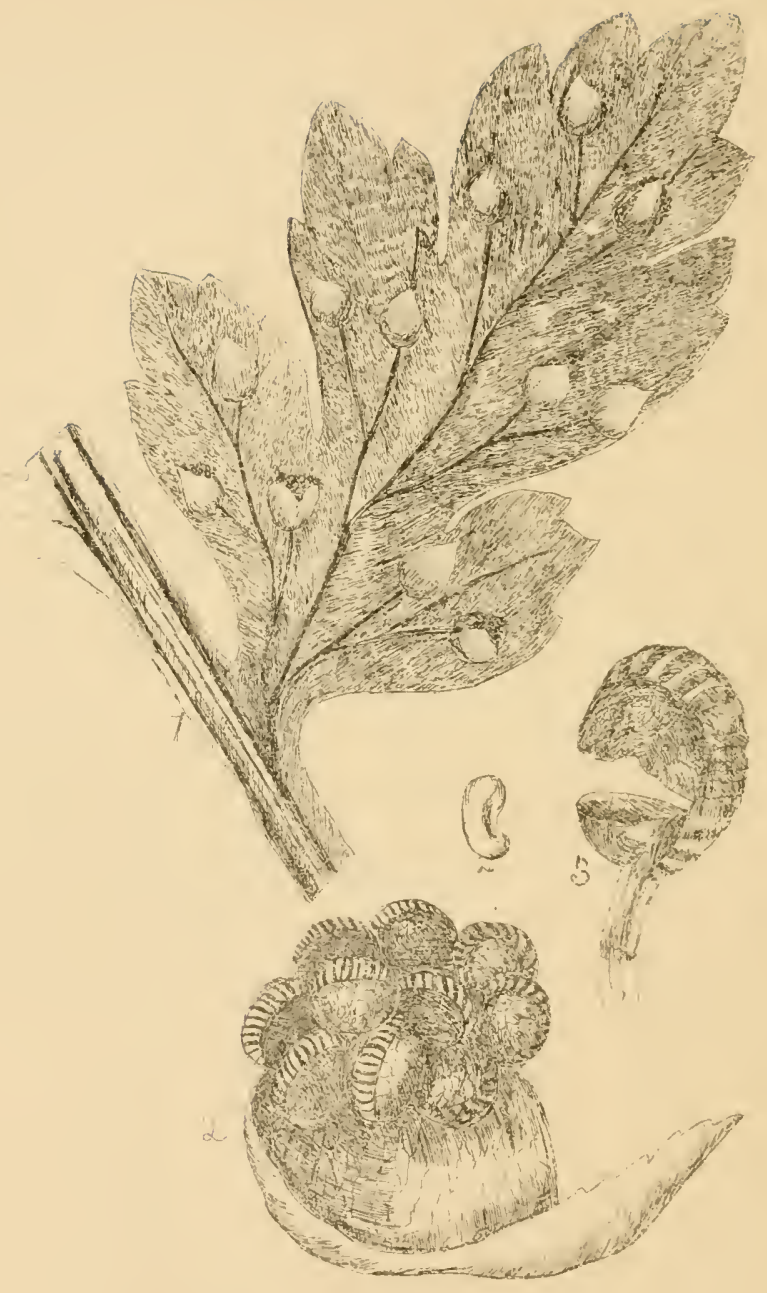




\title{
Plate XXXVII.
}

\section{CYSTOPTERIS. Bernhardi.}

\author{
BLADDER FERN.
}

Gen. Char.-Fruit-dots roundish, on the back of the free veins; indusium inflated, attached by a broad base beneath the under side of the sorus, opening toward the apex of the segment; veins forked.

This is a small genus of fragile ferns, chiefly confined to the temperate latitudes, though the $\mathrm{C}$. fragilis has a very wide range, and might almost be included in Mr. Redfield's Cosmopolitan division. The illustration, taken from Hooker and Bauer, gives a magnified view of the leaflet, showing the arrangement of the fruit-dots, the sorus, with the indusium laid open, and the sporange with its spore, all highly magnified. The indusium, or covering, of the fruit-dots is in the form of a small leaf, broad at the base and tapering to a point. This character can only be observed with the aid of a pocket lens. The sori are situated on the veins a little short of the apex, while in most other ferns they are at the ends of the veins.

The common name of Bladder Fern is given to plants of this genus on account of the peculiar inflated appearance of the indusium when fully mature. Only three species are found in this country-the C. montana, from Alaska, the C. fragilis and C. bulbifera; both of the latter being common. 



\section{.}




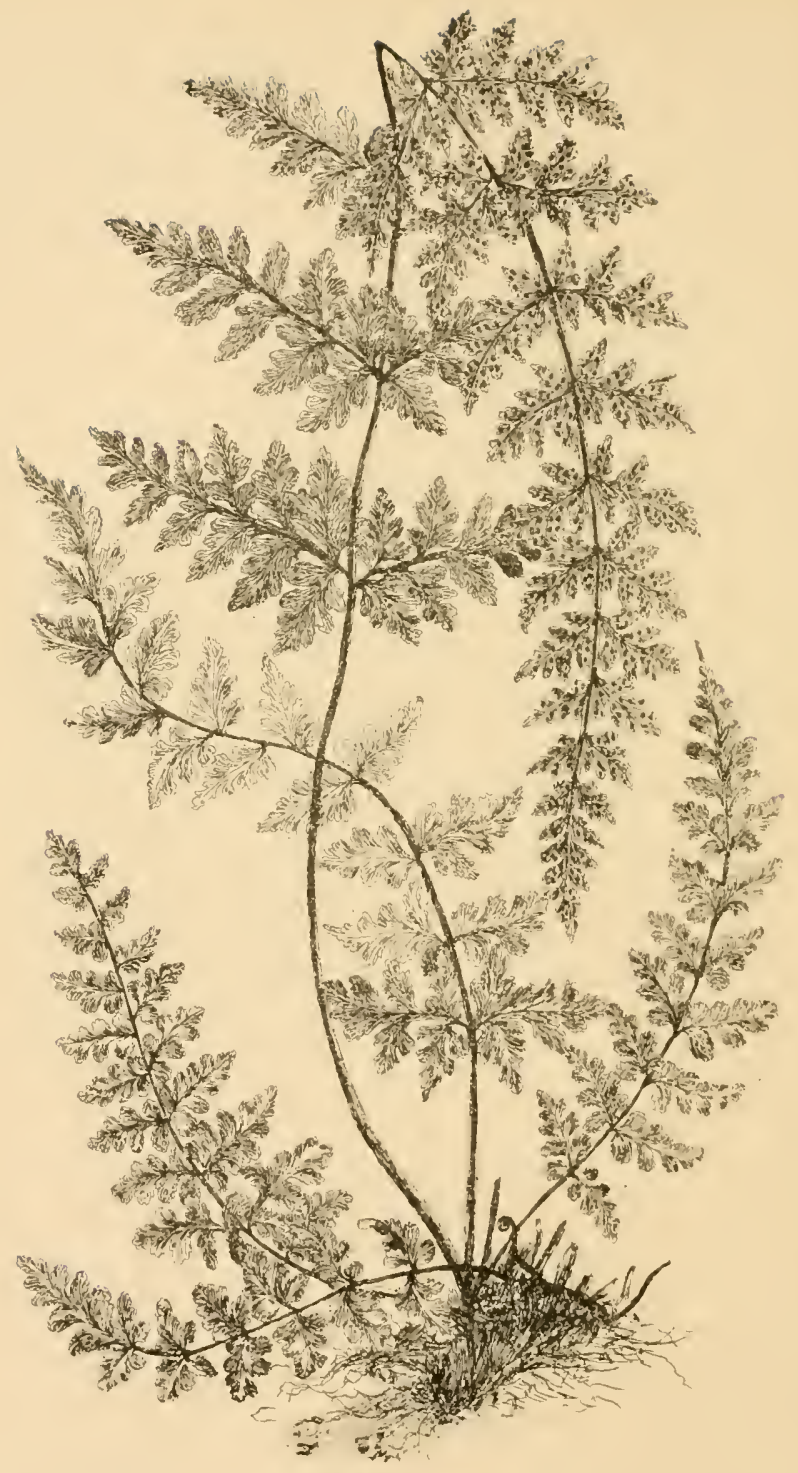




\section{Plate XXXViII.}

\section{CYSTOPTERIS FRAGILIS. Bernhardi.}

COMMON BLADDER FERN.

This is one of the earliest of our native ferns to welcome the coming spring. It is a fragile, delicate little plant, sending up its scroll-like fronds before the snow has scarcely left the ground. In our Kentucky woods its first companions are the Spring Beauty, the Hepatica, and the Violets. Its usual habitat is the crevices of damp and dripping rocks, where the soil is deep and rich; and it is found in great luxuriance in deeply-shaded woods, with fronds quite two feet in height, strong and erect, profusely covered with fruit-dots. In such places the scaly root-stock, ten or twelve inches long, seems to spread out in every direction; when confined to the rocks, the root-stock is more tufted, the fronds broader and not so high. From the great number of seedlings found during all the summer months, the spores would seem to germinate readily. These tiny seedlings are very convenient for examination, showing the structure and venation much better than the older plants. The pinnæ of the young fronds are more ovate and closer together than in those farther developed. At first the plant is of a light green color, soft and smooth, growing coarser as it grows older, with the addition of a few scattered chaffy scales.

It is represented in the Plate of natural size, with its tufted root and fronds in various stages of growth. The full-grown frond is bent over so as to show the under side.

It is easily cultivated wherever a good rich soil is supplied, being easily raised in the Wardian case, in mounds, or on rock-work. 







Plate XXXIX.

\section{CYSTOPTERIS BULBIFERA. Bernhardi.}

Bulbous Bladier Fern.

The specific name, bulbifcra (bulb-bearing), applied to this plant, is much more characteristic than many of the scientific names given to plants. On the underside of the rachis and pinnæe are situated, at intervals, several little bulbs, which the amateur might readily mistake for organs of fructification. They are, however, in no way connected with the fruit-bearing function, but are mere excrescences, or expansions of the epidermal tissue.

This plant has the same general appearance as the C. fragilis, with much longer lanceolate fronds, often two feet in length, with lance-oblong pinnæ. The stem is so frail and delicate that it seldom supports the plant in an upright position, but allows it to bend over upon the rocks or the surrounding vegetation. It is not so common in Kentucky as the preceding species. But it is found in numerous localities, on the cliffs of the Kentucky River (Short), and notably at Rock Springs, in Oldham County, where it grows in moist situations in the greatest luxuriance. It is a very tender fern, withering at the first touch of frost, and difficult to cultivate. 



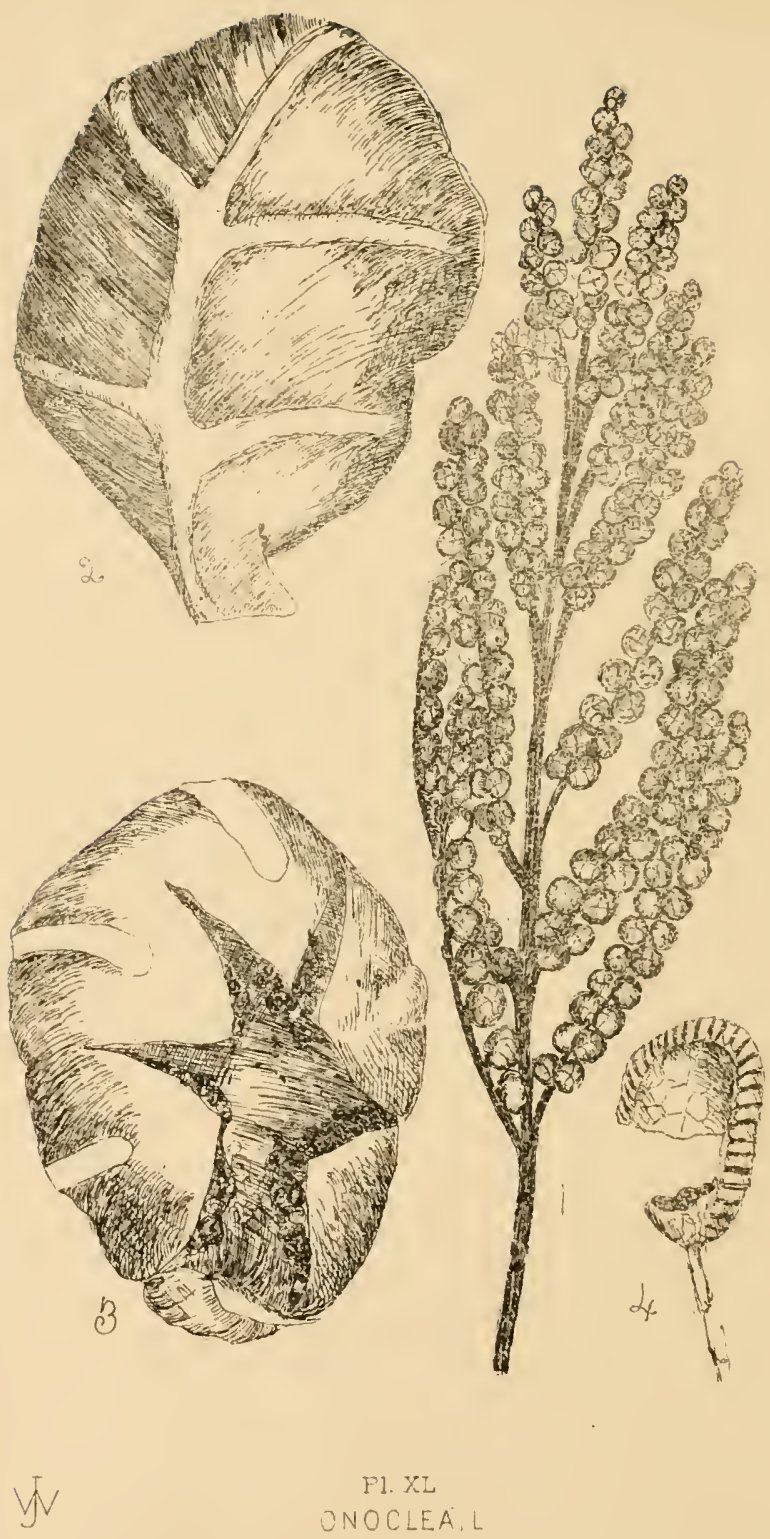




\section{Plate XL.}

\section{ONOCLEA. Linnæus.}

Ge.v. Char. - Fruit-dots round, one on the middle of each primary vein, soon confluent; sterile and fertile fronds unlike, the latter much contracted; indusium very thin, attached by its lower side, opening toward the apex of the pinnule; veins finely reticulated.

This is a very distinct and well-marked genus, characterized by its having the sporangia incased within berryshaped, closed involucres, formed from the revolute pinnules. The fertile frond is erect, growing from the center of the tuft, bearing its fruit-capsules in a one-sided spike or raceme. The long-stalked sterile fronds are triangular in outline, and are given off separately from the creeping root-stock.

In general appearance it does not resemble any of the rest of the Polypodiacex, the fertile fronds especially differing widely from those of other members of the group. The peculiar character of the sporangia, however, with their vertical incomplete ring, fixes beyond question its place in this natural sub-order. The figures which I have presented are all taken from the excellent work by Hooker and Bauer. I regret that the smallness of the Plate did not permit me to give the entire series of magnified veins.

Figure I represents the fruit-bearing portion of the fertile spike, natural size; figure 2, an upper view of a fertile pinnule; figure 3 , an under view of the same, showing the sporangia through the membranaceous indusium; figure 4 , the sporangia bursting open. 




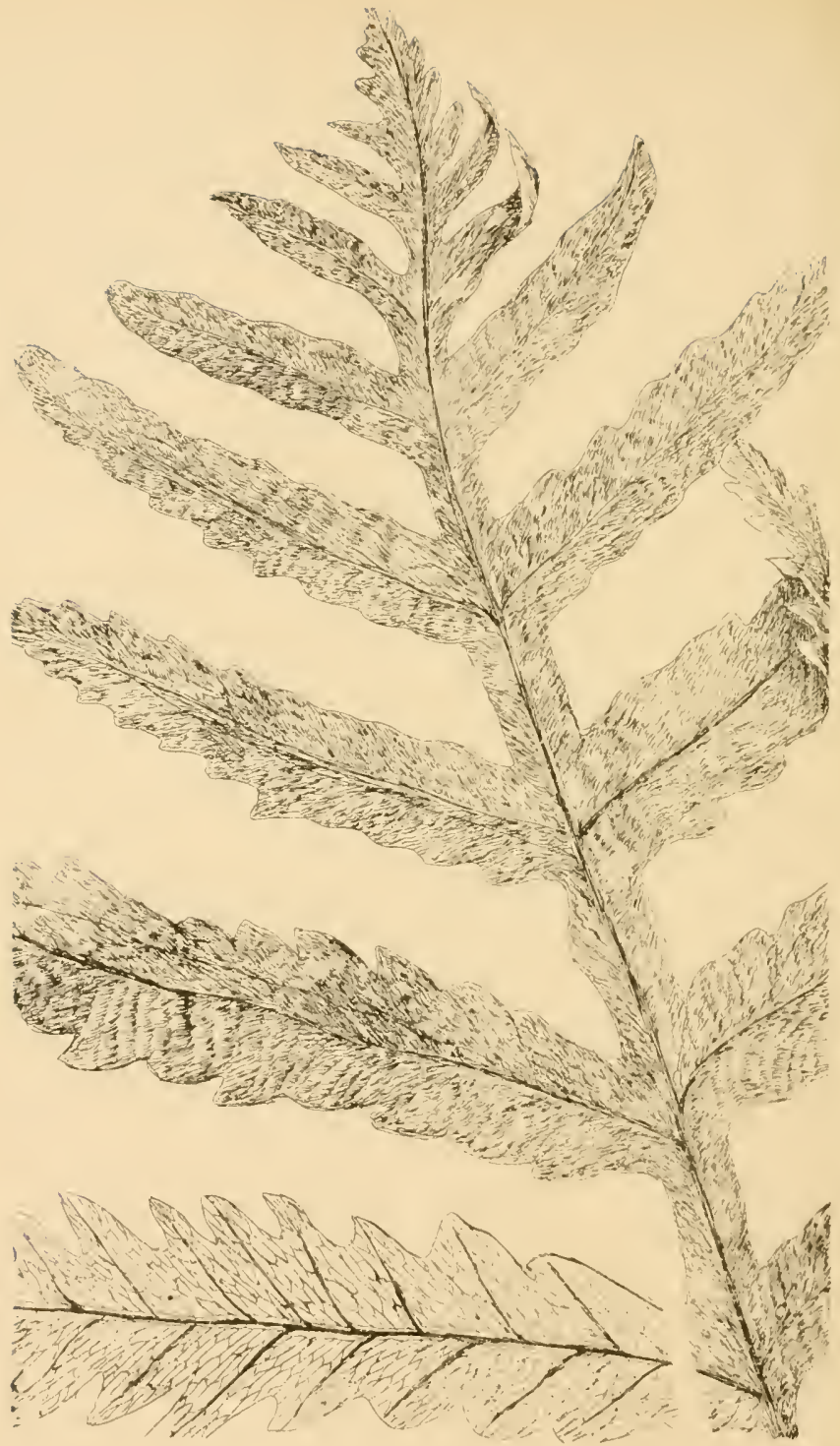


Plate XLI.

\section{ONOCLEA SENSIBILIS. Linnæus.}

Sensitive Fern.

The Sensitive Fern is the only species of the genus found in this country, and though common to the regions east of the Mississippi, it has in fact a very limited range. Mr. Redfield says, "Onoclea sensibilis, though absent from Europe and most of Asia, appears in Mantchooria and Japan. I am not aware that it now occurs in the western portion of our own country; but it is a very interesting fact that it has been discovered in a fossil state in the eocene tertiary of Montana." *

It is one of the most common of all our Kentucky ferns, and is met with in swamps and marshes, associated with the Osmunda regalis and $\mathrm{O}$. cinnamomea. It is sometimes called the Oak Fern from the resemblance of its deeply cleft leaf to that of the oak. The common name of Sensitive Fern, derived from its Latin specific name, conveys no idea whatever of its peculiar character, as sensibility is the very least of its attributes.

A variety is sometimes found in which some of the pinnæ of the sterile frond become contracted and pinnatifid, bearing fruit-dots as in the fertile; but $I$ have found, in such cases, the sporangia wanting, while next year the abnormal frond would resume its original form. It is simply a further illustration of the law of morphology, which is applicable to every member of the vegetable kingdom. It is easily cultivated. The Plate represents a portion of the sterile frond, with its delicately-reticulated veins.

* Geograph. Distrib. of Ferns. Bull. Torr. Bot. Club, vol. vi, p. 4. 




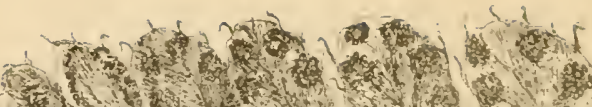
z- 50 .

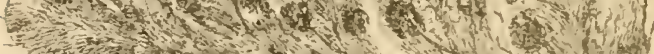

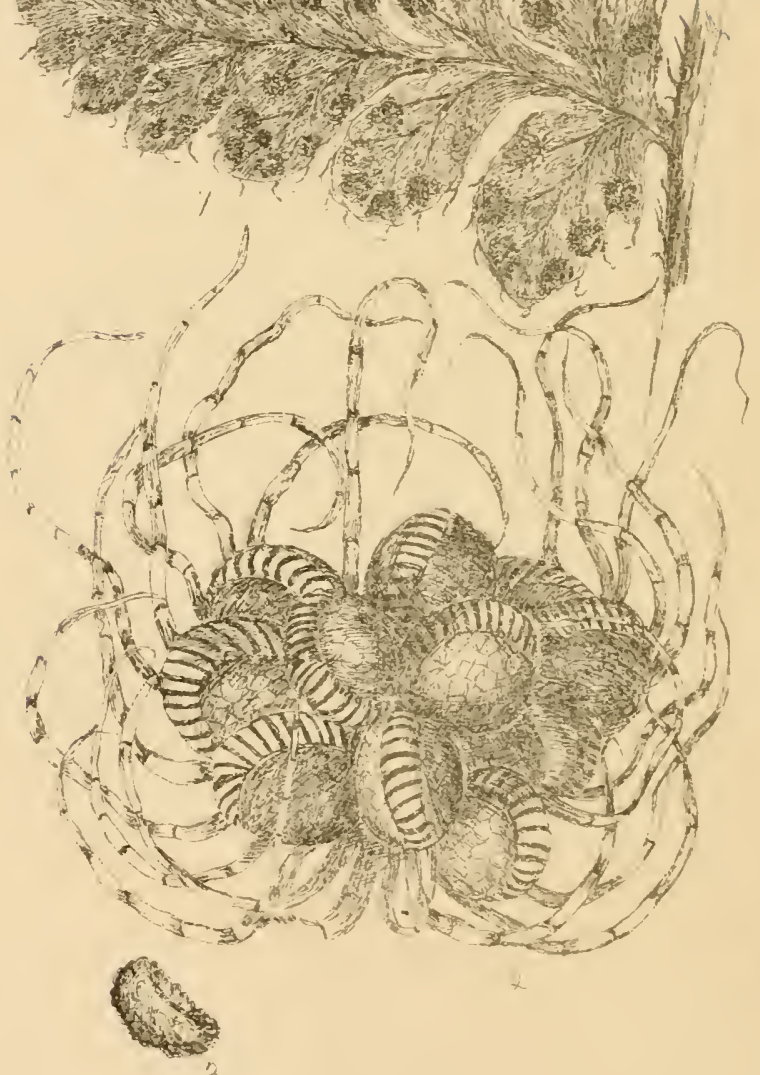


Plate XliI.

\section{WOODSIA. Robert Brown.}

Gen. Char. - Fruit-dots roundish, scattered on the back of simply-forked, free veins; indusium attached under the sori, bursting at the top into numerous jagged segments.

This genus, named in honor of Joseph Woods, an English botanist, author of the "Tourists' Flora," is represented in this country by six species of small, tufted, pinnately-divided ferns, all of which, with a single exception, are properly northern species, though I have doubtfully added another, so as to include all the species likely to be found in this geographical region. The Woodsia is widely dispersed in temperate latitudes, extending in Europe from the East Indies to Great Britain, and, on the western continent, from British America to Peru, with the exception of the intermediate tropical region.

The indusium, instead of covering the sori, as in nearly all the other ferns, is attached beneath them on the frond. While young, however, the sporangia are inclosed within the indusium, which forms a sort of cup. As the frond develops the cup-like indusium bursts open, forming in some species, after it spreads out, a number of articulated hair-like bodies composed of irregular cylindrical cells. Figure I represents the magnified portion of a frond; figure 2, sori magnified; figure 3 , spore magnified. Figures 2 and 3 are from Hooker and Bauer. 




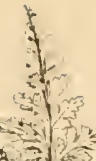

S.t. feflof

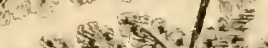
ind 1

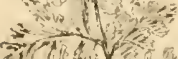

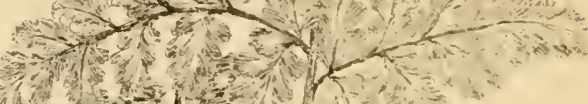

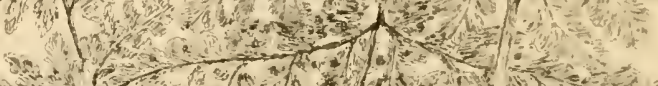

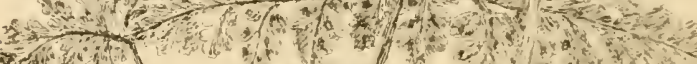
740 of 1.

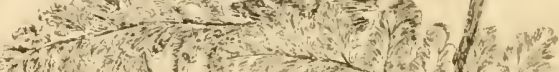
Ftiver w

Siv

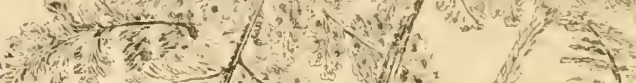
and

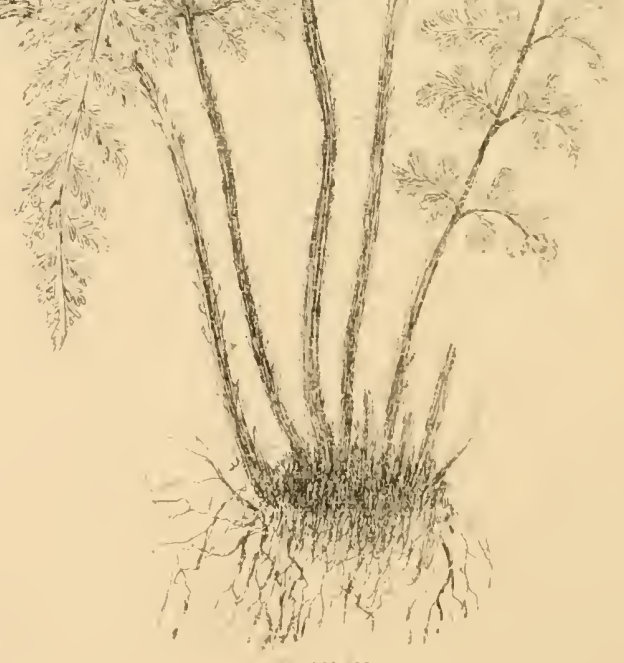


Plate XliII.

\section{WOODSIA OBTUSA. Torrey.}

OBtUSE-LEAved WoOdSIA.

This fern might possibly be mistaken for the Common Bladder Fern (Cystopteris fragilis). It has the same general appearance, grows to about the same size, and has somewhat the same habitat. But these ferns have no relationship. The frond is lanceolate, broader than in the Cystopteris, and the stipe and pinnæ are glandular-hairy. The indusium of this species differs somewhat from that represented in the magnified view of W. Ilvensis (Plate XLIV), splitting into jagged lobes, instead of being lacerated into a fringe of bristly, chaffy hairs. It is the Aspidium obtusum of Willdenow, and the Polypodium obtusum of Swartz.*

The Obtuse-leaved Woodsia is frequently met with in Kentucky in exposed situations, being better able to endure the direct rays of the sun than most ferns. In such places the pinnæ are often very much contracted, so that they seem to be crisp, and apparently quite rolled up. I obtained the best specimens of this fern from exposed, outcropping rocks on Beargrass Creek, Jefferson County. The tufted roots were deeply imbedded in the soil of the larger crevices.

The Woodsia grows well in mounds, on rock-work, in hanging-baskets, or in the Wardian case.

* See Willd. Sp. Pl. V, p. 254, and Swartz, Synop. Filic. 39. 



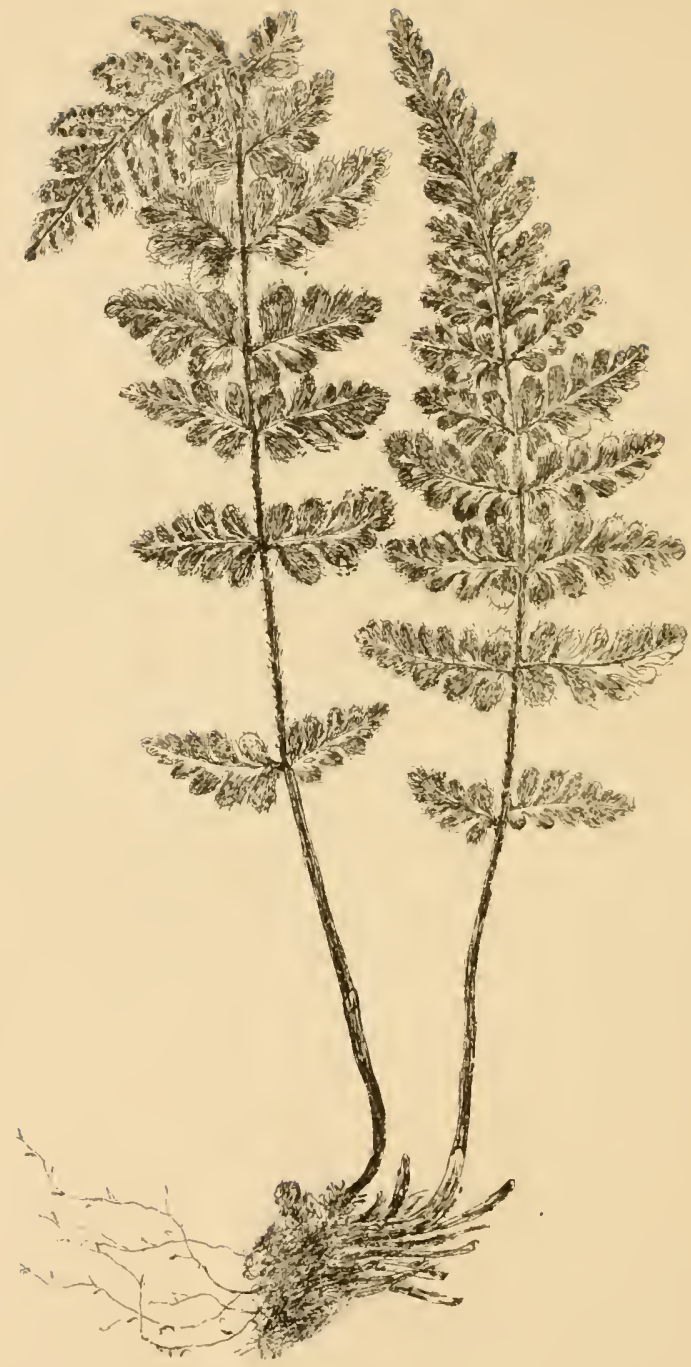

y

PI. XLIV

WOODSIA ILVENSIS, R BROWN

El oa njodsia 
Plate XliV.

\section{WOODSIA ILVENSIS. Robert Brown.}

\section{Elba Woodsia.}

This is a small, tufted species, not more than five inches high, with oblong-lanceolate fronds, bearing pinnately-parted crowded pinnæ, the lower more widely apart than those toward the apex. The pinnules are numerous, obtuse; the points somewhat crenate, with the fruit-dots near the margin, and confluent, at least on the mature fronds. The whole plant, especially on the under sidc, is covered with rusty, chaffy hairs. The articulation of the stipe is characteristic. Unlike the Polypodium the joint is not at the root-stock, but from a half an inch to one inch above the base, and much less distinct. When the frond decays it always breaks off at this place, and not at some indefinite point of the stipe, as in most ferns.

I have not been able definitely to give this beautiful little fern "a local habitation and a place" in Kentucky, although there are reasonable grounds for believing that it inhabits the rocky spurs of the great Appalachian chain, along the eastern border of the State. As it is the most characteristic species of the genus, and as it may help local collectors to identify this representative of a more northern latitude, I have included it among the Kentucky ferns.

It is the Nephrodium rufidulum of Michaux, and is found in the Northern United States and Canada, and, according to Gray, southward in the Alleghanies; and is therefore very properly referred by Mr. Redfield to his Boreal region. The counties of Boyd, Martin, Pike, Harlan, Bell, and Whitley, by their altitude, are well adapted 
to be its home; and botanical students or local collectors are requested to report any discovery they may make of it in this region.

The etching represents a plant, natural size, which was kindly furnished me by Prof. J. M. Coulter, of Hanover College, Indiana. 



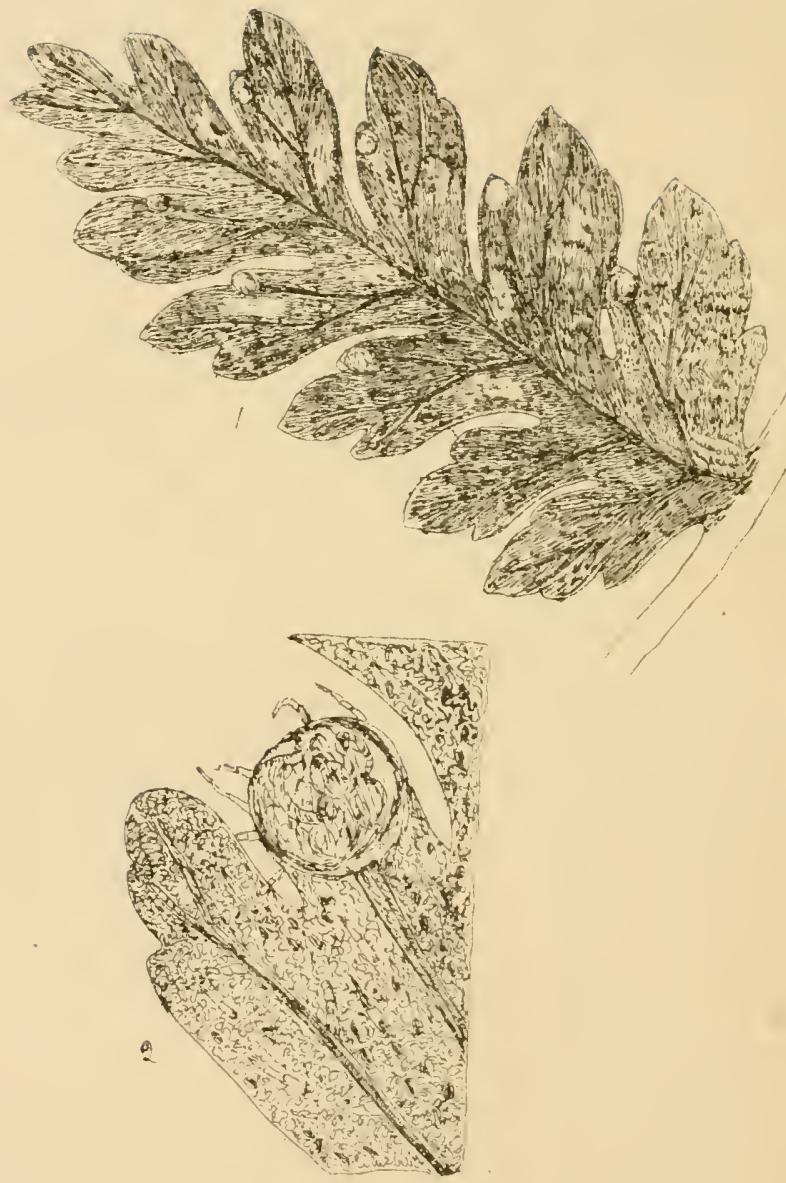




\section{Plate Xlv.}

\section{DICKSONIA. L'Heritier.}

GEN. Char.-Fruit-dots very small, marginal, at the apex of a free vein or fork; indusium cup-shaped, membranaceous, opening at the top, and partly adherent to the reflexed margin.

This genus, named in honor of James Dickson, a noted English cryptogamic botanist, furnishes some of the most noble and graceful specimens of the vegetable kingdomthe Tree Ferns of the tropical islands of the Pacific and Indian oceans. The form and arrangement of the organs of fructification, however, as in other ferns, determine their place in the order of Filices. A single unpretentious species represents the genus in this country.

It belongs to the tribe Davalliex, characterized by its having the sporangia inclosed within a slightly-recurved lobe of the pinnule. A magnified view of the pinnule, showing the venation and the position of the fruit-dots, is given in the Plate. Figure 2, still more magnified, shows the reticulated structure of the leaf-tissue and the cup-shaped indusium or involucre bursting and discharging the sporangia.

Hooker, in his "Genera of Ferns," says that "the indusium or involucre appears to be formed of a dilated (at length membranaceous) portion or tooth of the frond, which unites with a scale arising from the apex of a nerve on the under side of a pinnule." There is formed, at first, a nearly globose, entire indusium, which soon bursts at the top, sometimes with a transverse cleft, and sometimes with an irregular circular opening. In all the specimens which I have examined the opening was irregular. A number of delicate microscopic hairs may be found on the margin of the indusium. 




\section{Plate XLVI.}

\section{DICKSONIA PUNCTILOBULA. Kunze.}

\section{SWEET-SCENTED FERN.}

This is the only American species of the genus, and is not common in Kentucky, though Prof. Hussey reports it as growing abundantly in Edmonson County. I have some beautiful specimens from the banks of Silver Creek, Clark County, Indiana, only a few miles from Louisville. They grow on loose, shaly rocks, apparently without much nourishment. It may be readily mistaken by the young botanist for the Lady Fern. But a careful examination of the fruit-dots, in well-developed plants, will enable him to identify it at once.

The frond is about two and a half feet high, lanceolateovate, and twice pinnate. The pinnules are exceedingly regular in outline, resembling patterns for decorative designs. The whole plant is covered with numerous little glands which emit, when crushed, a very pleasant odor.

This fern has a trailing root-stock, and is very difficult to transplant, but with care it may be made to grow very well. It needs plenty of room in which to develop its graceful fronds.

A piece of a frond, natural size, is shown in the Plate. 




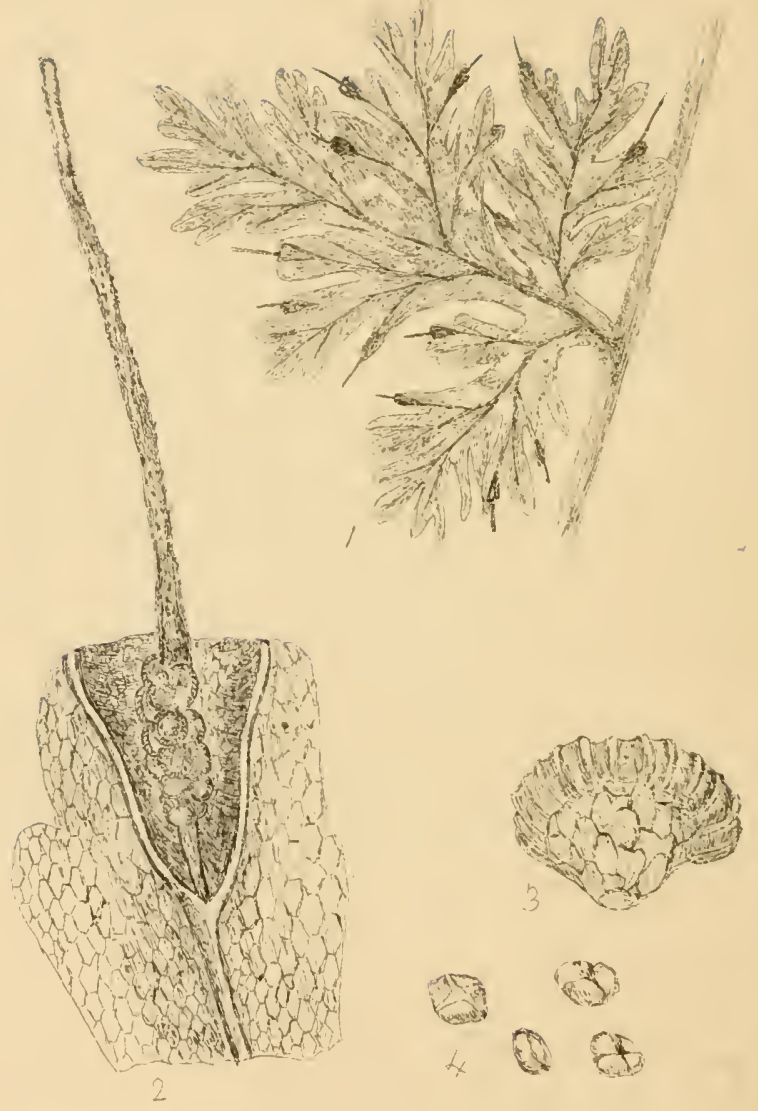


Plate Xlvil.

\section{TRICHOMANES. Linnæus.}

Gen. Char.-Fruit-dots marginal, at the ends of free veins; indusium urn-shaped, cylindrical, in which the sporangia are borne upon an elongated receptacle (columella); the frond delicate and pellucid.

The genus Trichomanes is the only representative of the sub-order Hymenophyllaceæ in this country. It differs widely from any of the ferns yet described, not only in the form and arrangement of the sporangia, but in the peculiar texture of the foliage, and the disposition of the capsules upon the frond. The pellucid appearance of the leaf-tissue is common to all the Hymenophyllaceæ. This transparency is due to the fact that the fronds have but a single layer of cellular tissue, while the darker veins are composed of several layers of compact tissue. In many respects they resemble mosses more than true ferns; and, accordingly Prof. Sachs assigns them the lowest place in the fern family, next to the mosses. But the unfolding of the leaf, as well as the venation, is exactly like that of the true ferns.

The sessile sporangia are situated upon a long columella, inclosed in an urn-shaped involucre, upon the ends of the free veins at the margin of the leaf. The apex of the urnshaped body does not project beyond the margin of the lobe of the pinnule, but the column or bristle is prolonged beyond it a quarter of an inch. This column, under the microscope, presents a series of spiral scars at the points where the sessile sporangia have been attached.

The ferns of this group are confined to damp, secluded situations, shrivelling up when exposed to the direct rays 
of the sun. I have found species of the Hymenophyllum on the island of Arran, Scotland, growing in localities similar to those occupied by the Trichomanes radicans in this country.

Figures 2, 3, and 4 give microscopic views of the urnshaped involucre, sporangia, and spore. The drawing is from that of Mr. Bauer, in Hooker and Bauer's "Genera of Ferns." After a careful examination of the specimens found in Kentucky, I can see no difference in them from the representations by Mr. Bauer, except that in our specimens the column seems to arise from the thickened cellular tissue a little above the base of the involucre. 
Plate XLVIII. (Frontispiece.)

\section{TRICHOMANES RADICANS. Swartz.}

Bristle Fern. Killarney Fern.

This exceedingly rare fern has a black, wiry, creeping root-stock, with somewhat drooping fronds of very variable outline. The texture of the leafy portion is thin and delicate, with the veins surrounded by a sort of pellucid fringe, as in all the filmy ferns (Hymenophyllaceæ). The plant is from three to ten inches high. The leaf-stalks have a kind of membranaceous keel or wing, and are smooth or somewhat rusty.

The name of Killarney Fern was given to it by the English botanists on account of its being found, in Great Britain, only in the neighborhood of the Lakes of Killarney, Ireland. Previous to 1872 it had only been reported as found in Alabama and Tennessee (Gray), in this country; but in that year it was discovered in Carter County, Ky., by Dr. H. H. Hill, of Cincinnati. Carter County is in the northeastern portion of the State, near the borders of IVest Virginia. In the years 1873 and 1874 it was collected by Prof. Hussey in the same county, and in Edmonson and Barren counties. In Barren County, Prof. Hussey says that he "found it in more than twenty localities, always on rocks or moist earth, far under overhanging cliffs, at least where moisture never fails, and the direct rays of the sun do not reach during many minutes of the day. Usually the fronds are bedewed with moisture trickling from the rocks on which they grow."

In 1876 Mrs. L. P. Yandell, of this city, found it in Laurel County, near Rockcastle Springs. In a letter to the author she thus describes the place where it was found: 
"My second view of the Trichomanes I can never forget. At a point where the immense cliff seemed to have suddenly parted, forming an angle of forty-five degrees, a small stream of water was falling from the top, a distance of about two hundred feet. In this angle, twenty feet above my head, was a fairy grotto about three feet deep and ten feet in circumference. It was lined above, below, and within with Trichomanes glistening in the spray of the falling water, many of the leaves eight inches longa translucent fringe-deeply embowered in the shade of the overhanging cliffs and rhododendrons, where no ray of sunshine had ever penetrated. The face of the cliff is about three hundred yards from the river, and the point where the plant grows is pure sandstone. These cliffs are the crowns to hills covered with great varieties of foliage, and the glens which lead up the middle of these arcades are filled with the rankest vegetation. The cliffs here form arcades from the banks of the river, which run from north to south."

In the summer of $r 877$ Dr. Crosier, of Louisville, found it on the divide between the head waters of the Rockcastle River and the South Fork of the Kentucky River. It grew beneath an overhanging ledge of sandstone, where the rays of the sun never penetrated, and where it was kept constantly moist with water trickling from above. One of the Liverworts (Marchantia) was found growing with it in great abundance. The rocks overhead were fringed with rhododendrons.

Prof. Hussey, who first identified Dr. Hill's specimens, and who has made himself familiar with it in its native habitats, has kindly sent me the following account of it: "The thin, wiry root-stocks, densely clothed with roots or trichomes, are woven into a dense mat and come off in 
great masses, from which portions have to be torn. The fronds do not develop the fruit until they have been mature for some time-apparently not until they are at least a year old, perhaps older. Then the ends of the veins enlarge and grow beyond the margin of the frond. A season is occupied in developing the first cluster of spores. At the end of the second year the frond has borne some fruit; but the process of fruit-bearing continues for several seasons. The bristle, upon the base of which the sporangia grow, continues to develop, its base always covered with new sporangia. This bristle, when not broken off, becomes half an inch or more in length. By means of a sufficientlyhigh magnifying power the scars left on the bristle by the breaking away of the foot-stalks of the sporangia may be plainly seen. We can not tell how many years a single frond of Trichomanes radicans may live. It must exist five or six years, possibly more. It is difficult to command the conditions necessary to make it grow in cultivation. It will remain in a natural condition many months under a moist bell-glass, if aired occasionally to prevent molding. In 1877 I gave a portion in a fresh state to 'William,' a guide at the Mammoth Cave, to plant near the mouth of the cave, and I have since learned that it is doing well."

Mrs. Yandell brought a few plants of this fern from Laurel County, two summers ago, and placed them in a pot filled with fibrous peat and sand. I have this fern in my possession, and it continues to put out new fronds. The vase is covered with a bell-glass, and is kept shaded from the sun's rays. 

. 

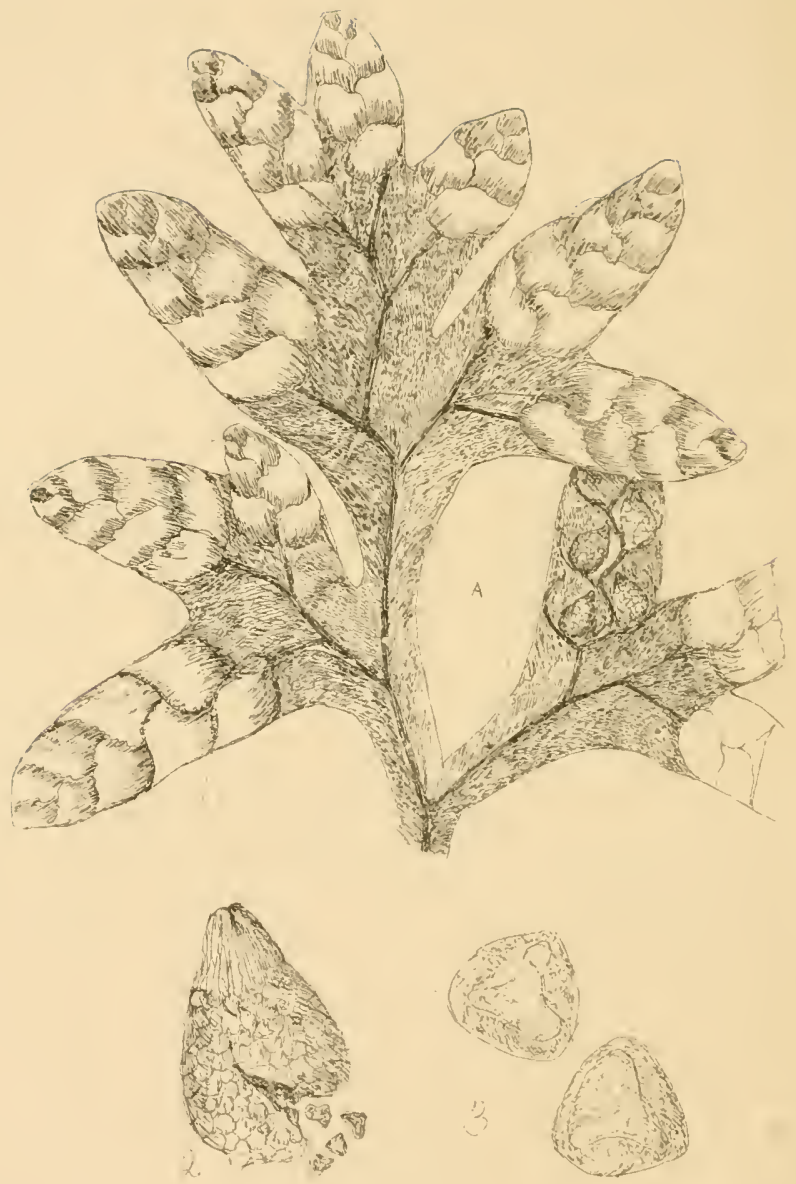
Plate Xlix.

\section{LYGODIUM. Swartz.}

Gen. Char.-Fruit-dots arranged on contracted pinnules of spike-like lobes, covered on one side by imbricate, hooded scales; fronds leafy, climbing.

This remarkable genus differs very much from any yet described, both from its general appearance and the peculiar arrangement of its fruit-bearing apparatus. It belongs to the sub-order Schizæaceæ, and is distinguished by its having the sporangia inclosed in the hooded scales of a two-ranked, imbricated spikelet. Figure I shows a portion of the fertile part of the frond magnified; $a$, the pinnules covered with imbricated scales (indusium); $b$, with the scales removed, exposing the sporangia fixed to the veinlet; figure 2, a sporange magnified fifty diameters.

It differs widely from all other ferns from the fact that it is a climbing plant. The species of this genus are mostly confined to the warmer regions of the globe, although the only one found in this country is able to endure the extreme cold of a New England winter. Four fossil species of Lygodium are described by Mr. Lesquereux from the tertiary, and one from the cretaceous deposits of the West.* Though these specimens are mere fragments of leaves, the peculiar nervation is well preserved, and is quite sufficient to identify the genus.

"See "Cretaceous Flora of the West. Territories," p. 45, plate i, figure 2 ; also, "Tertiary Flora," p. 6I, plate v, figures 4-9. 




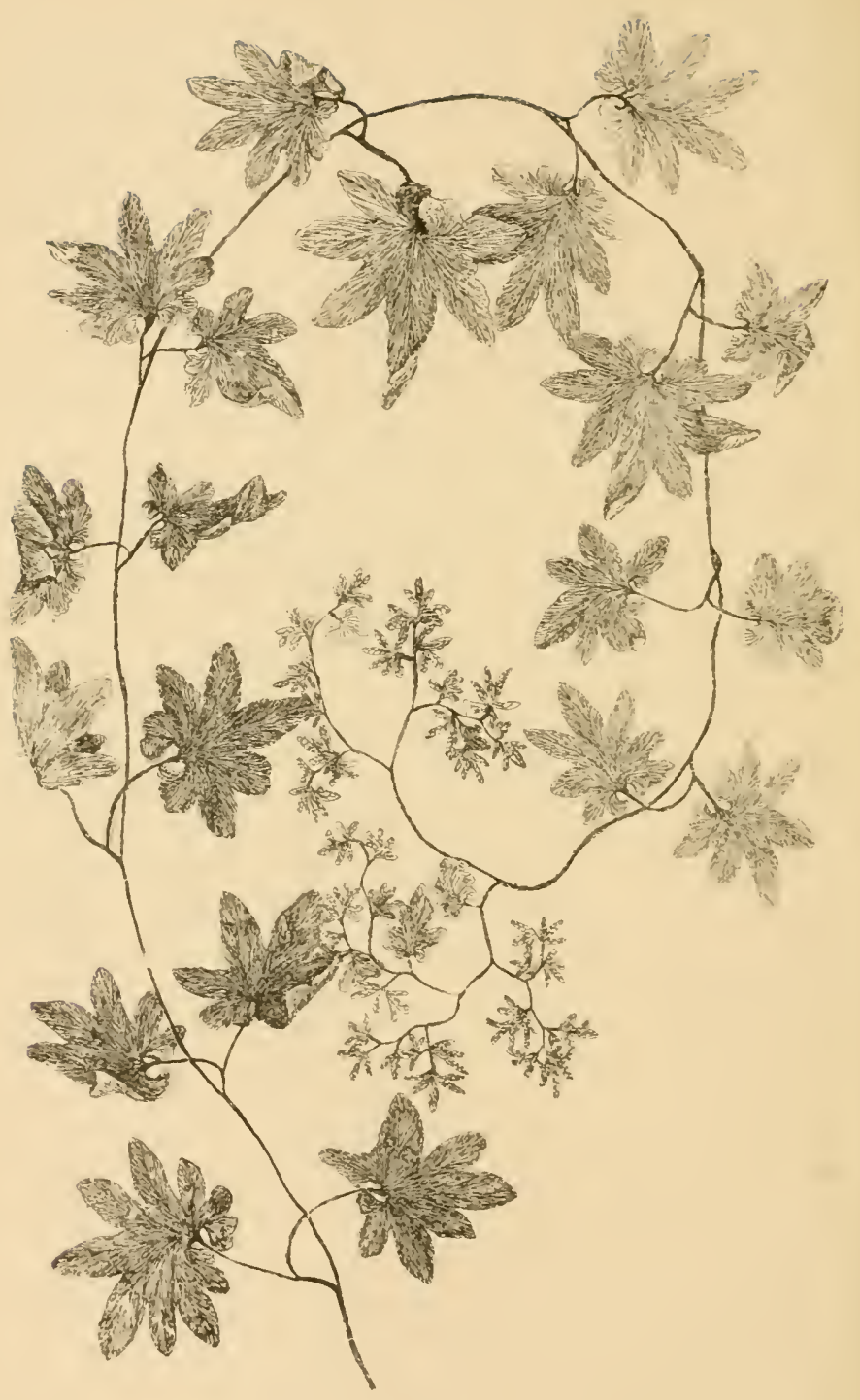


Plate L.

\section{LYGODIUM PALMATUM. Swartz.}

CLIMBING FERN.

The common name of this fern is very appropriate. It has a slender, twining stalk, bearing at intervals of a couple of inches alternate short branches; these are twice-forked, each subdivision bearing a palmate frondlet. The smaller fertile frondlets form a compound terminal panicle. The root-stock is creeping, and somewhat similar to those already described in many other ferns.

This is one of the rarest of our Kentucky ferns, and, of late years, has only been found within the limits of the State in a few localities. It had been previously given as indigenous to the State, in the works of Gray, Wood, and other botanists, without specifying localities, probably on the authority of Dr. Short, though I have not found it in the catalogues of either Short or Riddell. During the summer of ${ }^{8} 86$ Mrs. L. P. Yandell, of Louisville, and Miss G. H. Rule, of Philadelphia, discovered it at Rockcastle Springs, near London, Laurel County; and on a recent excursion (March, I878,) to Livingston, Rockcastle County, I found it growing in great luxuriance, covering acres of ground on the moist declivity of the range of hills extending from Livingston to Pine Hill. The masses of twining fronds matted together and interlaced in a thousand directions, reminded me of clusters of dodder. Prof. Crandall, of the Kentucky Geological Survey, reports the Climbing Fern on the Cumberland table-lands near Crossville, Tenn.; it is found in the Carolinas (Nuttall), in the western part of Virginia, on the borders of Kentucky and Tennessee (Michaux), and in Florida (Chapman). 
The Trichomanes and Lygodium, so far as our present knowledge extends, are both exceedingly rare in Kentucky, and we earnestly hope that these lovely ferns, however tempting they may be to fern collectors, may be left in their native habitat. Mr. Martindale, of Camden, New Jersey, in the "Botanical Gazette," for December, 1876 , gives an account of seventeen species of ferns collected by Miss Rule, at Rockcastle Springs, among which was the Lygodium palmatum. 



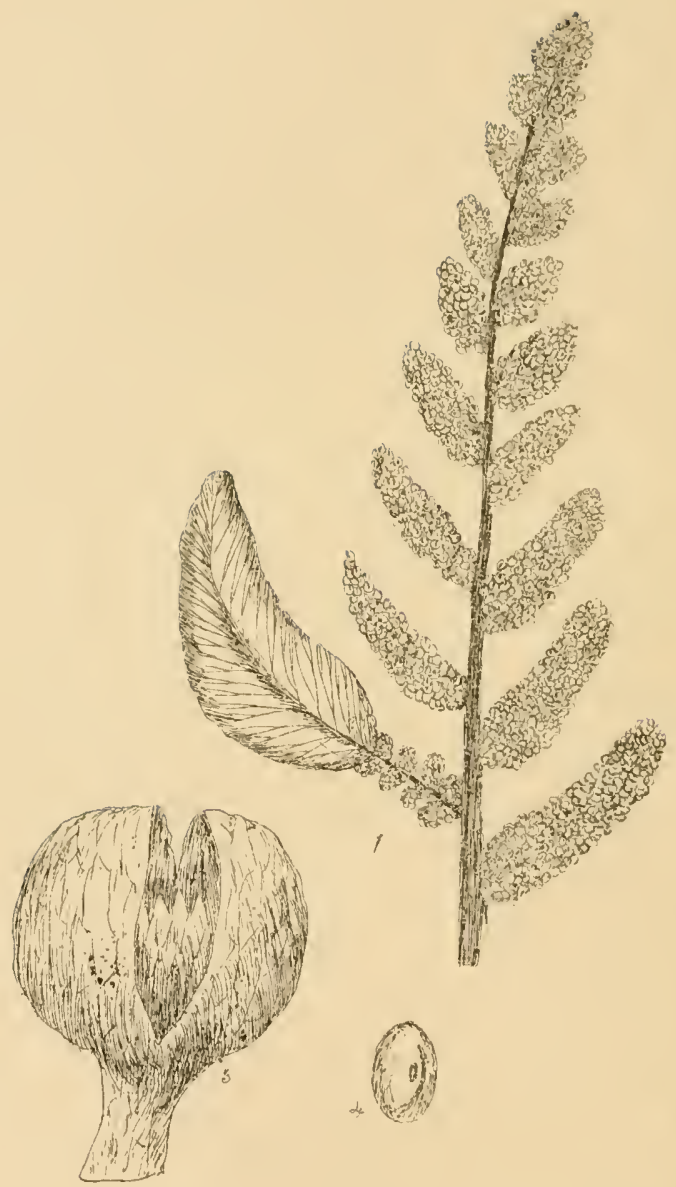

W 
Plate LI.

\section{OSMUNDA. Linnæus.}

Gen. Char. - Sporangia globular, short-stalked, destitute of an indusium, clustered on the margin of the much-contracted fertile frond, or portion of frond.

This is the typical genus of the sub-order Osmundacex, and its characteristics are quite distinct. Figure I represents a portion of a fertile frond slightly magnified; figure 2, sporangia and spores greatly magnified, the globular sporangia with two valves opening from the top. The fertile part of the frond is very much contracted, the pinnules being sometimes broad and foliate on one side, and narrow, with fruit-capsules, on the other.

This genus has three representatives in this country, all found in Kentucky. They are tall stately plants, growing usually in low, wet grounds in the neighborhood of swamps and marshes. The fertile fronds, with their clusters of ferruginous sporangia, amid the masses of green foliage, serve to make them exceedingly picturesque. A fossil species is described from the Tertiary of the Western Territories.*

* See Lesquereux's Tertiary Flora, p. 6o, pl. iv, fig. I. 



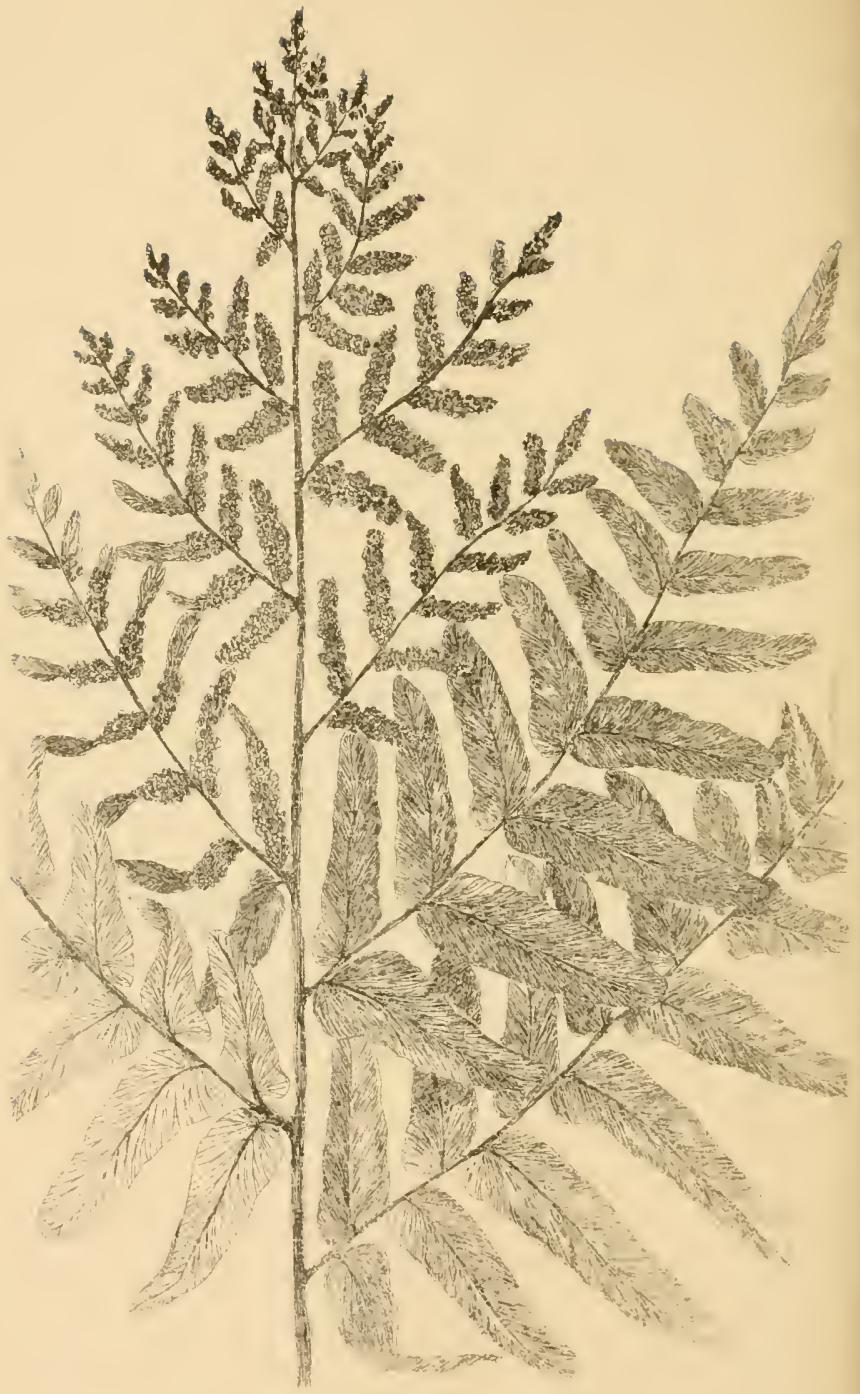


Plate LII.

\section{OSMUNDA REGALIS. Linnæus.}

Royal Flowering Fern.

This species is the best known of the Flowering Ferns, and has a wide geographical range, both in this country and in Europe. It is much admired on account of its majestic size. Moore describes it as sometimes growing, in England, to the height of eight or ten feet. But it rarely attains, in the United States, such stately dimensions. In the Wet Woods, four miles south of Louisville, it grows to great perfection, but I have never secured specimens over four feet in height. Along the Rockcastle River, for miles, it grows in such profusion that it holds a predominant place in the vegetation of that region. It flourishes in all the swamps and low lands of this State, and may be found along the alluvial banks of most of our water-courses. The sterile frond is twice-pinnate, the pinnæe with about ten pairs of leaflets; the fertile frond is also twice-pinnate, with a dense racemose panicle of fruit-capsules (sporangia) at the top. When fully ripe this fruit-panicle has a showy appearance, like a flowering plant in fruit, whence its name of Flowering Fern.

The scientific name of this fern has been the subject of much conjecture. Sometimes it has been said to be derived from Osmunder, the Saxon name of the Scandinavian Thor, and sometimes from Osmund, a traditionary personage, of whom the following story is told:

"At Loch Tyne dwelt the waterman, old Osmund. Fairest among maidens was the daughter of Osmund, the waterman. Her light brown hair and glowing cheek told of her Saxon origin, and her light steps bounded over the green 
turf like a young fawn in his native glades. Often in the stillness of a summer's evening did the mother and her fairhaired child sit beside the lake to watch the dripping and splashing of the father's oars as he skimmed right merrily toward them over the deep blue waters. Sounds as of hasty steps were heard one day, and presently a company of fugitives told with breathless haste that the cruel Danes were making way toward the ferry. Osmund heard them with fear. Suddenly the shouts of furious men came remotely on the ear. The fugitives rushed on. Osmund stood for a moment; then snatching up his oars he rowed his trembling wife and fair child to a small island covered with the great Osmund Royal, and, helping them to land, bade them lie down beneath the tall ferns. Scarcely had the ferryman returned to his cottage when a company of Danes rushed in; but they hurt him not, for they knew he could do them service. During the day and night did Osmund row backward and forward across the river, ferrying troops of those fierce men. When the last company was put on shore, Osmund, kneeling beside the river's bank, returned heartfelt thanks to Heaven for the preservation of his wife and child. Often in after years did Osmund speak of that day's peril; and his fair child, grown up to womanhood, called the tall fern by her father's name."

The Royal Fern may be readily cultivated in mounds, with a rich, deep soil which retains the moisture, and is not exposed, at any time, to a parching summer sun. 



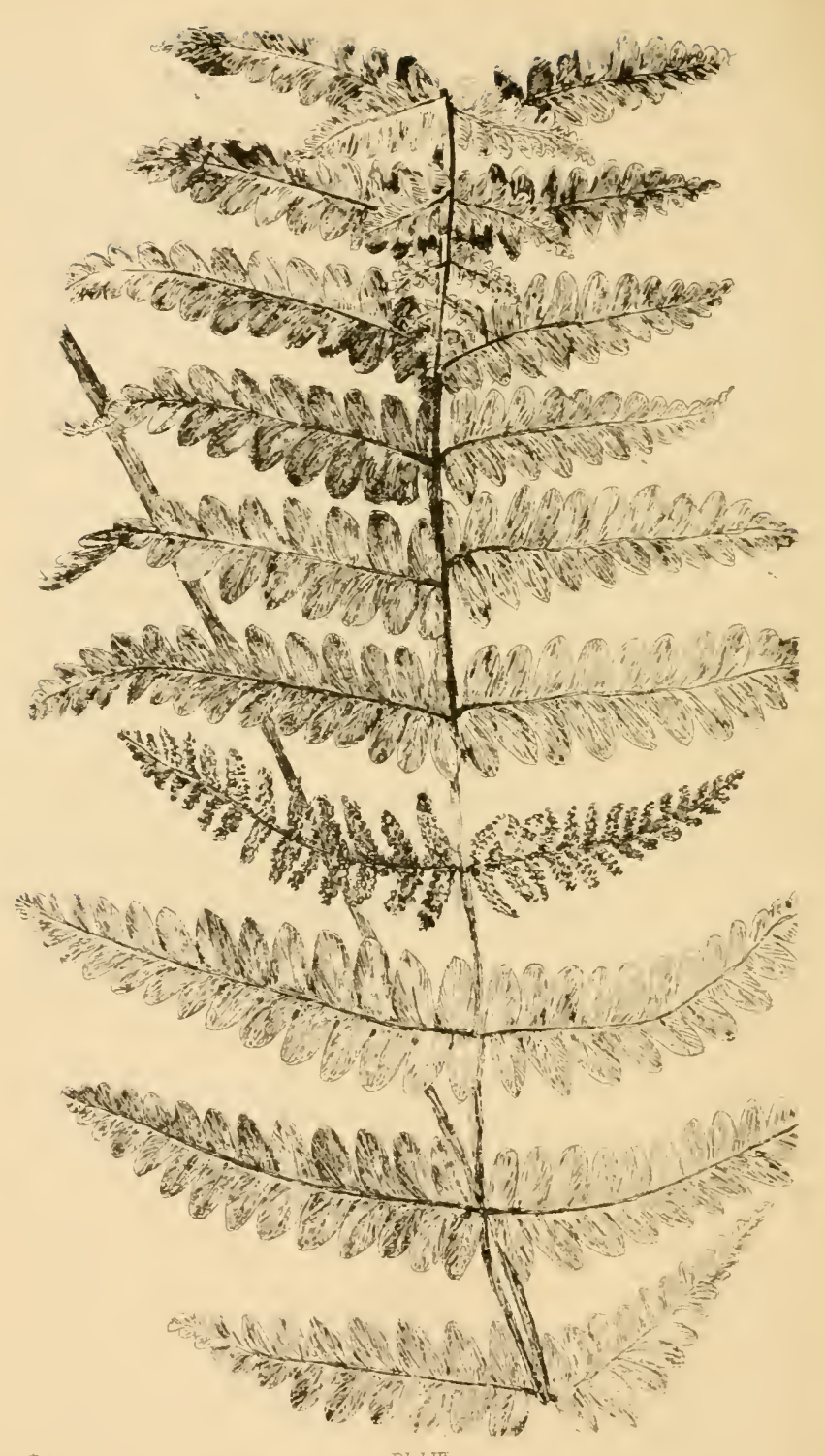




\section{Plate LIII.}

\section{OSMUNDA CLAYTONIANA. Linnæus.}

Clayton's Flowering Fern.

This curious fern is the O. interrupta of Michaux, which is really the most appropriate name, on account of the fertile frond being interrupted at intervals near the middle with contracted pinnze bearing the fruit-capsules; but the older name of Claytoniana claims the precedence. The Plate only shows the interrupted fertile frond, the sterile being very similar but broader. The transformation of the leaf-tissue into fruit-bearing organs is well exhibited in this plant. It grows to the height of about two and one half feet, and, when young, is clothed with a fine woolly substance which disappears when older.

This plant is found in all our damp, rich woods, but is not so common around Louisville as the $O$. regalis. In Rockcastle County it is very abundant, as is doubtless the case in all the deep, rich woods of the mountain counties. 




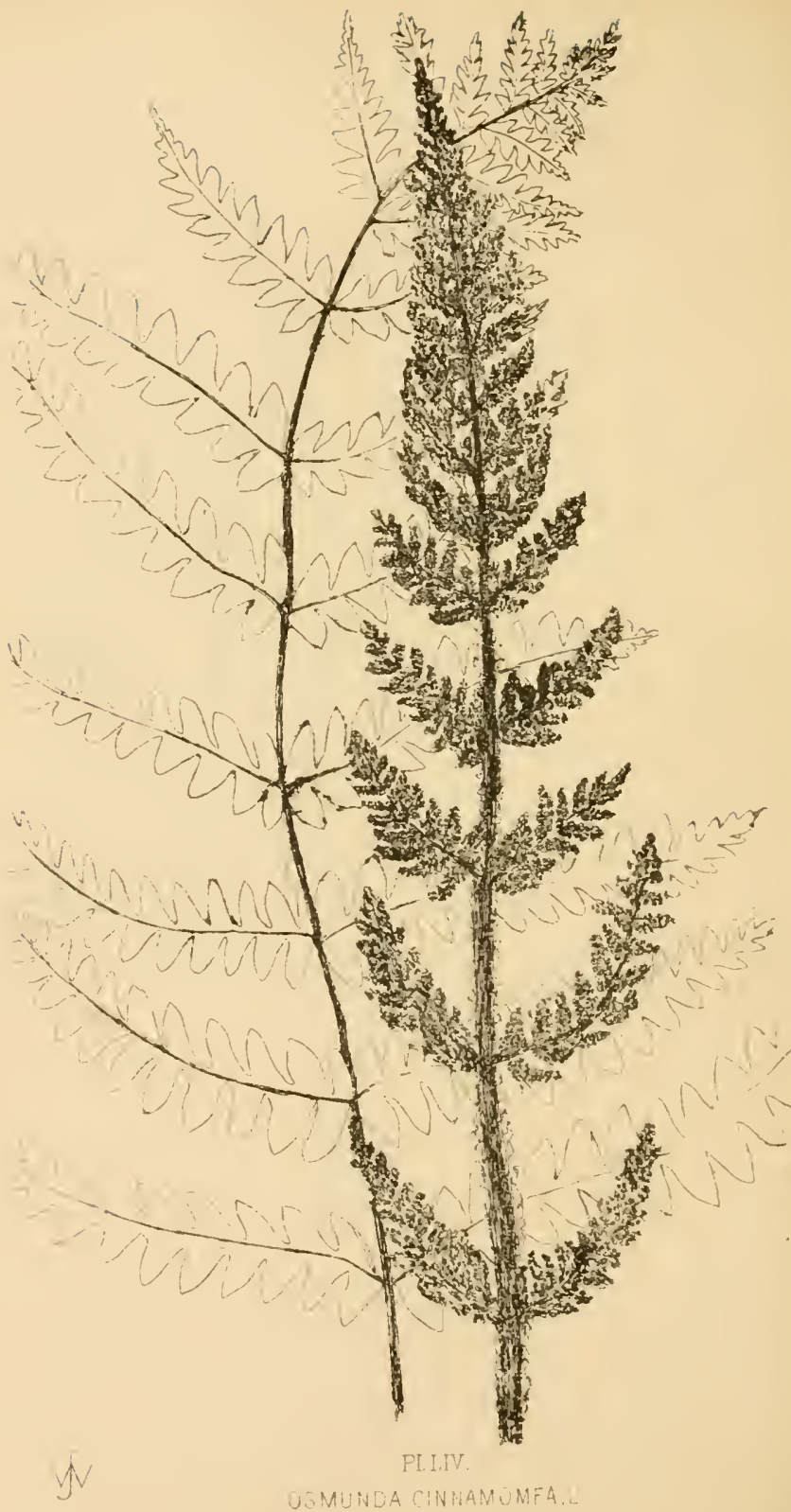




\section{Plate LiV.}

\section{OSMUNDA CINNAMOMEA. Linnæus.}

\section{CINNAMON FERN.}

This is the only one of the Flowering Ferns in which the fertile frond differs very materially from the sterile. In early summer it sends up a tall frond thickly clothed with rusty wool. This frond is twice-pinnate, and is composed entirely of cinnamon-colored fruit-cases. The sterile frond bears opposite lanceolate pinnæ, with broadly obtuse divisions. The fertile frond is very short-lived, withering in the early part of July, either lying shriveled at the base, or hanging to the fertile frond, which has now arrived at its greatest perfection, and is very smooth. The latter often attains the height of five feet, a tall majestic plant which, in the swamps of the Northern United States, becomes a very conspicuous object.

The finest specimens I have obtained were found near Livingston, Rockcastle County. It grows also in the IVet Woods, near Louisville, and in a swamp at Prospect, on the Narrow Gauge Railroad.

On account of the great size of the Flowering Ferns, it is difficult to show any thing more than their general structure in the drawings. 



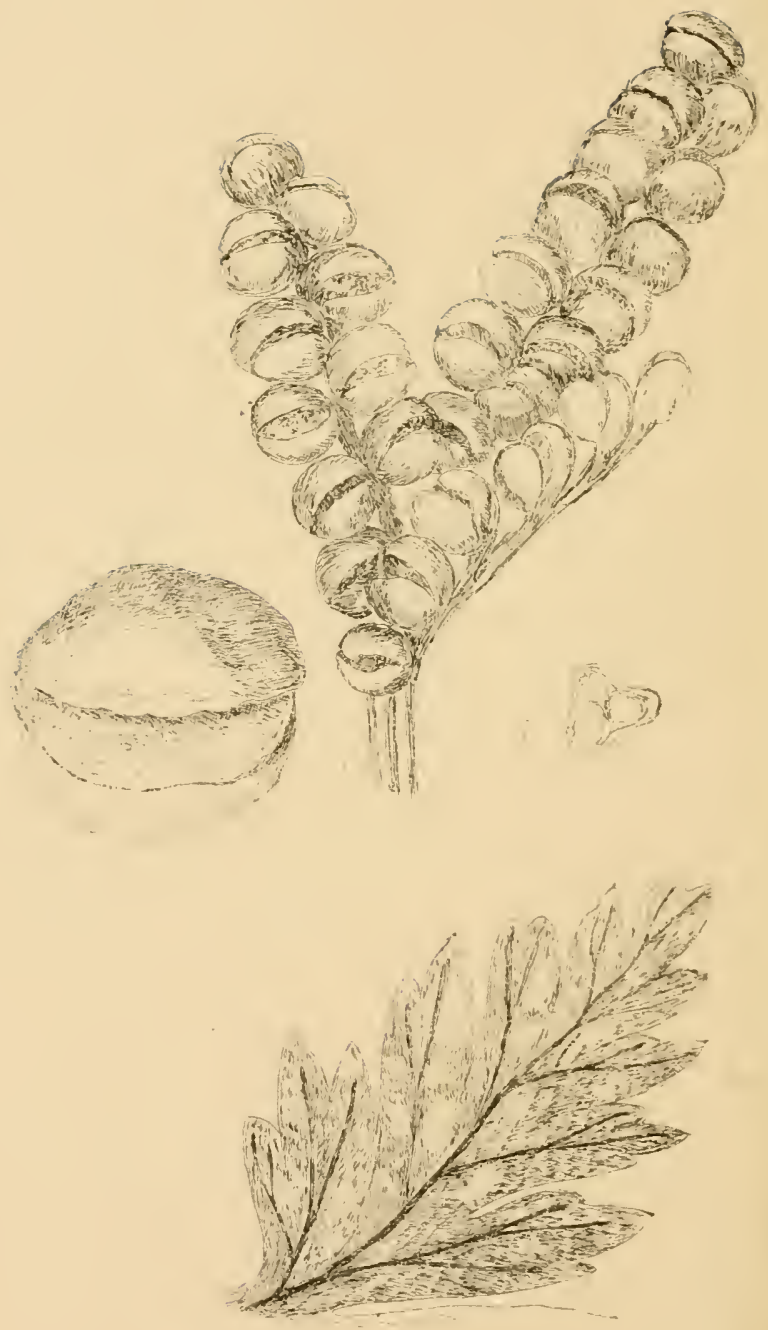

PILV 
Plate LV.

\section{BOTRYCHIUM. Swartz.}

MOONWORT.

Ges. Char.-Sporangia sessile, naked, on the margin of the I-3 pinnated rachis, arranged in a double row; fronds with a sterile and fertile segment, the fertile contracted; root fleshy; veins forked.

This interesting genus belongs to the sub-order Ophioglossaceæ, which, as has already been mentioned in the article on classification (Page 25), occupies a questionable place among the true ferns.* The genus is distinguished chiefly by its having the organs of fructification in an erect panicle, borne on a separate stem or branch of the frond. Hofmeister is of the opinion that the fertile frond is a shoot of the sterile one. The spore-cases, especially when young, resemble globular berries, which, as soon as they become mature, open vertically, presenting two symmetrical valves. These are somewhat coriaceous in texture, and opaque, and are destitute of an elastic ring, as in the true ferns. According to Davenport, external characters are not to be depended upon, the buds or spores furnishing the only unvarying characters by which the different species can be recognized. Each sporangium is an entire lobe of a leaf,

* For a full exposition of the Ophioglossacex I would refer the reader to the following works: Mettenius, Filices horte botanici Lipsiensis, 1856, p. 119; Milde, Monographia Botrychiorum, in Nova Acta Acad, Leop. Carolinx, IS58, vol, xxvi; Hofmeister, Germination, Development, and Fructification of the Higher Cryptogamia (Ray Soc.) IS62, pp. 307-317; Hooker \& Baker, Synopsis Filicum, I868; Sachs, Text-book of Botany, Eng. ed., I875, pp. 378-383; Davenport, Notes on Botrychium Simplex, 1877 ; Daven. port, Vernation in Botrychia, in Bull. Torr. Bot. Club, i 878 , vol, vi, pp. 193-199. 
the mother-cells of the spores being produced from the inner tissue.

How the Botrychium differs in its development and mode of growth from other forms of the Vascular Cryptogams must be left to the systematic works cited above. The excellent monograph, by Mr. Geo. E. Davenport, of Boston, has done much to simplify the subject, bringing to the notice of American readers the splendid researches of Milde, and, at the same time, supplementing them with his own careful investigations. Through his kindness I have been enabled to append to this work an etching from his Plate on the vernation in the Botrychia, drawn originally by Mr. Emerton (Plate LX).

The name Moonwort is derived from the crescent or moon shaped leaflets of the fronds of B. Lunaria, Swartz, a species but rarely found in the United States.

Plate LV, figure I, represents a fertile spike; figure 2, sporangium; figure 3 , spore; figure 4 , pinnæ of sterile frond of B. Virginianum; the last from nature, the rest from Hooker and Bauer. 

?

inhitis

$\rightarrow$ in

$3 x^{2}$.

and

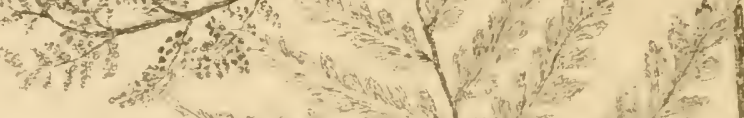
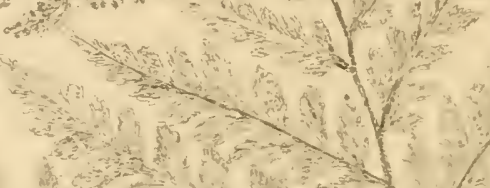

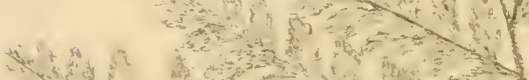
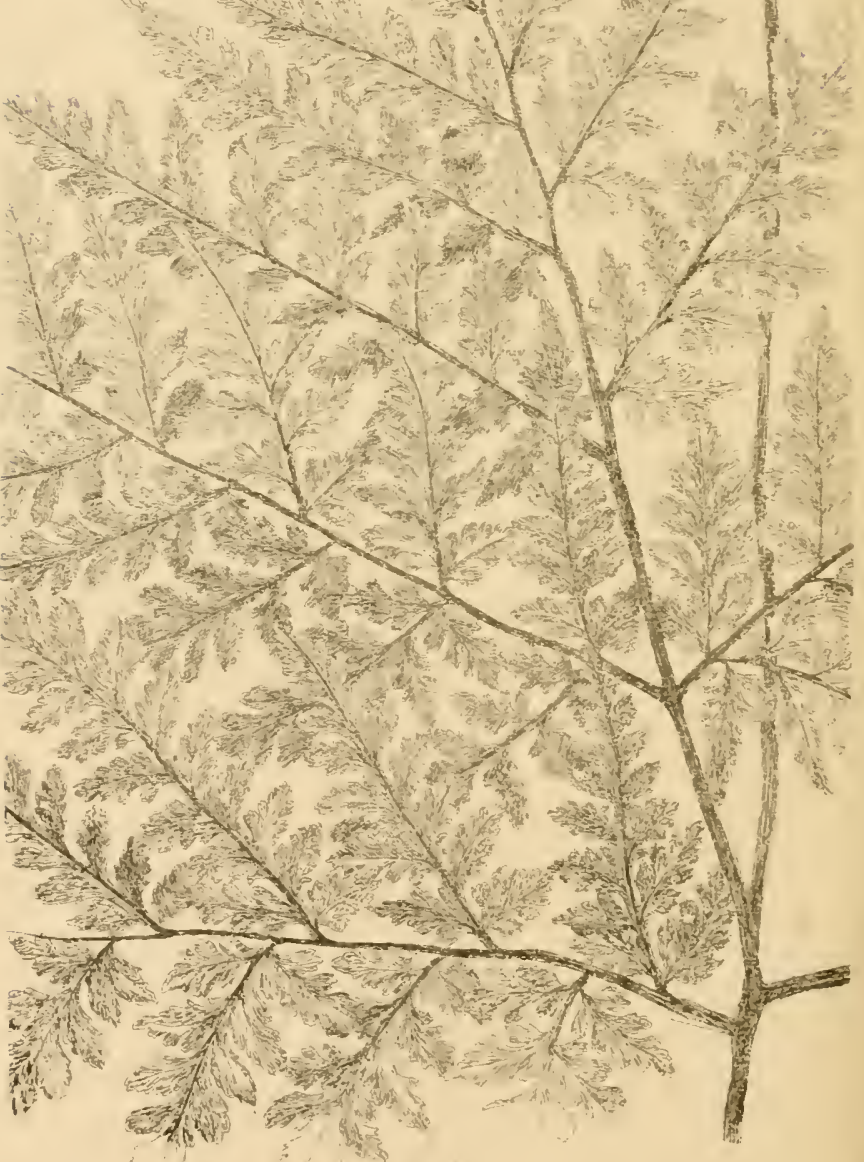
Plate LVi.

\section{BOTRYCHIUM VIRGINIANUM. Swartz.}

\section{VIRGINIA MOONWORT.}

This species is undoubtedly the handsomest of all our Moonworts. The sterile branch is sessile above the middle of the common stalk, and ternate, the lower pinnæ spreading, forming a broad triangular frond. About the beginning of May, if growing in a rich soil, the plant possesses a thick, fleshy texture, which is lost when it attains maturity, becoming thin, delicate, and membranaceous. It is very variable, both in form and size. I have seen specimens two feet high and sixteen inches broad, measured from the points of the lower pinnæ. It is common in Kentucky in damp, rich woods, where there are plenty of moisture and leaf-mold. In a dry, sterile soil it becomes slender and dwarfed, whence Pursh was led to establish a new species, the $B$. gracile.* It is found very generally throughout the United States and Canada, though restricted by Mr. Redfield to the Appalachian region. Singularly enough this fern was placed by Linnæus $\dagger$ among the Osmundas, which differ from it very widely, both in general appearance and in the peculiar mode of fructification.

The Plate represents a portion of the plant, natural size, cut off at the point where the sterile branches off from the fertile frond. The fertile frond, in the Plate, does not show the fruit in such profusion as would appear on a better developed plant; yet it is sufficient to enable the student to determine the species without difficulty.

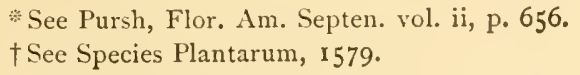





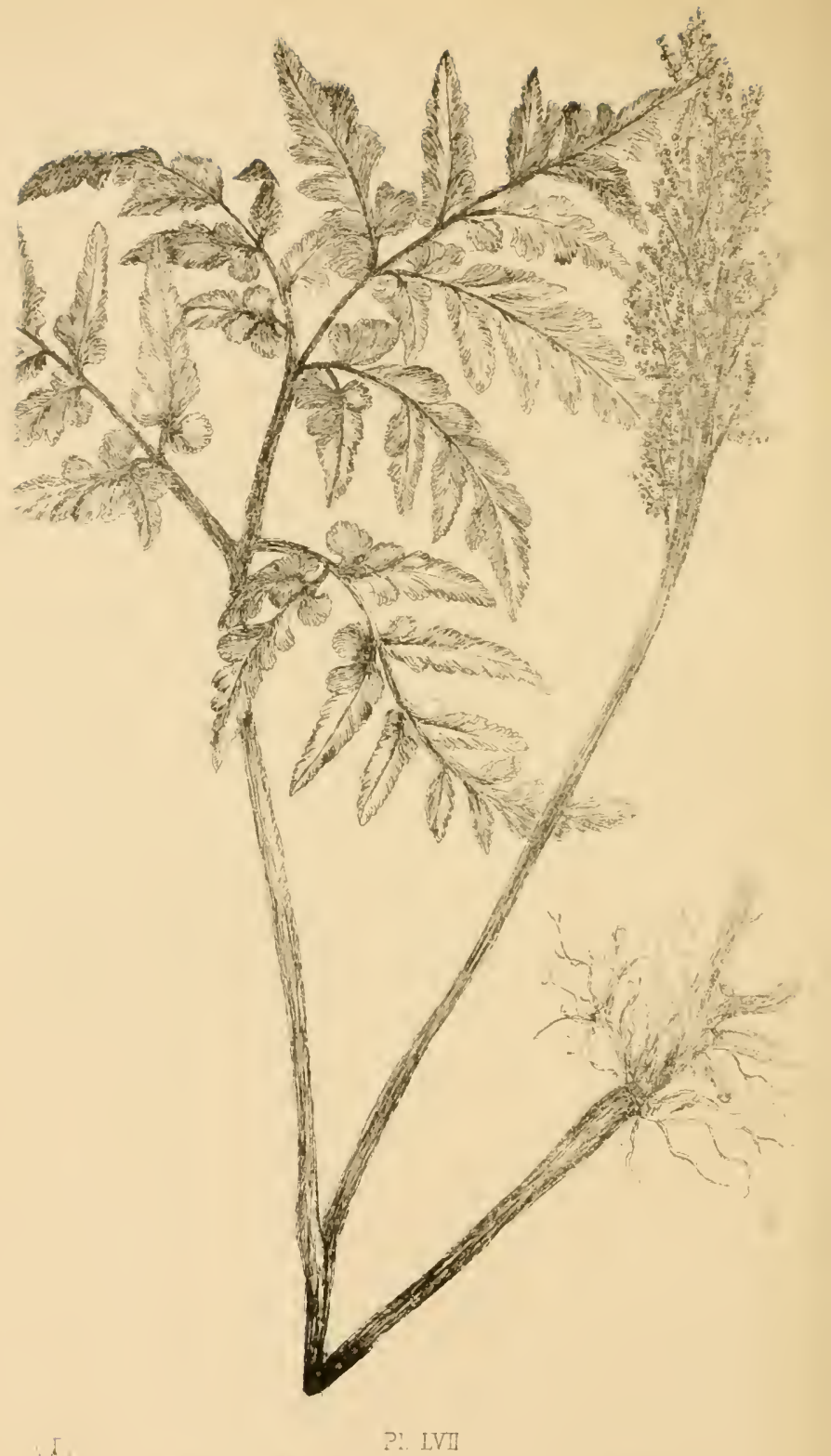


Plate LViI.

BOTRYCHIUM TERNATUM. Var. Obliquum. Milde.

TERNATE MOONWORT.

This Moonwort is easily distinguished from the preceding. The sterile panicle arises from the common stalk: near the ground, and is therefore long petioled. The texture of the plant is altogether different from that of the Virginia Moonwort, in being coarse, thick, and succulent. The sterile frond is ternate, with oblong or lanceolate divisions, and, in this species, oblique at the base, toothed or irregularly pinnatifid, somewhat wavy, crisp or recurved, as shown in the Plate.

This variety is the most common form of $\mathrm{B}$. ternatum found in Kentucky. It is found in all our woods, and arrives at its greatest perfection in the months of July and August. The fertile frond remains green all winter. The vernation in Botrychia is very important, and Mr. Davenport remarks that, "in $B$. ternatum and its varieties, the bud is very short and shaggy, the upper portion being so thickly covered with a hairy pubescence as to obscure the arrangement of the two fronds completely. This pubescence is wholly confined to the upper portion of the bud, the stalk remaining perfectly smooth." He further observes that he has not been able to verify Milde's statement "that in this species the apex of the fertile panicle is not only bent downward in the bud, but that the tip is again bent upward, being in fact sub-circinate, so that in his classification of the different kinds of vernation he places this species in a class by itself, which he calls "vernatio sub-circinata." He very justly says that, "if correct, this would be a most important point, and would 
show a much closer relationship to the true order of Filices than is usually recognized in this genus." *

This form of B. ternatum, Swartz, is the B. obliquum of Muhlenberg, which, in the earlier editions of Gray's Manual, was reduced to a variety of B. lunarioides, Swartz, but Milde's arrangement is now generally adopted in this country, and is undoubtedly most in accordance with nature.

The plate represents a plant of natural size.

* Vernation in Botrychia, l. c. p. 196. 



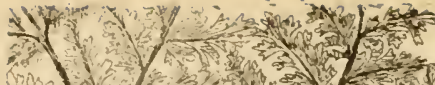

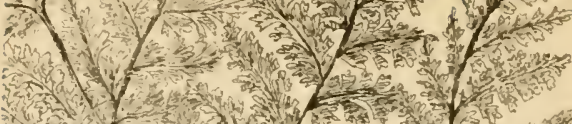

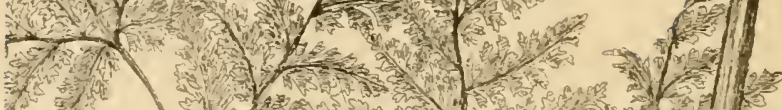

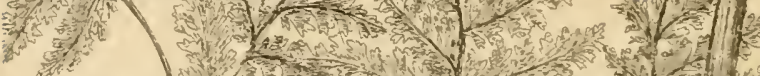

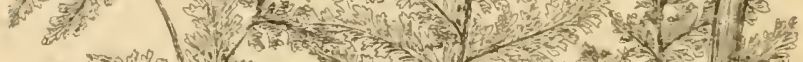

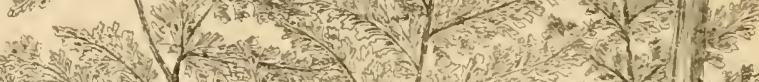

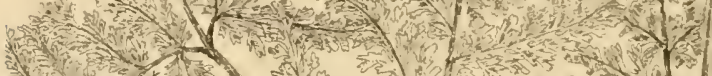

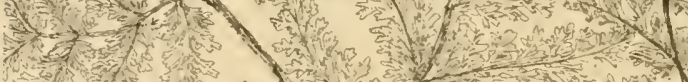

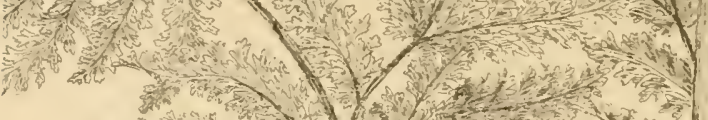

$\log _{1}, y=$

(1)
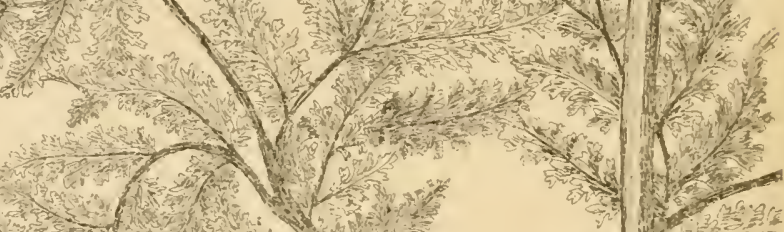

a - I

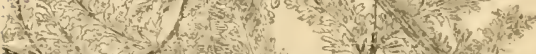

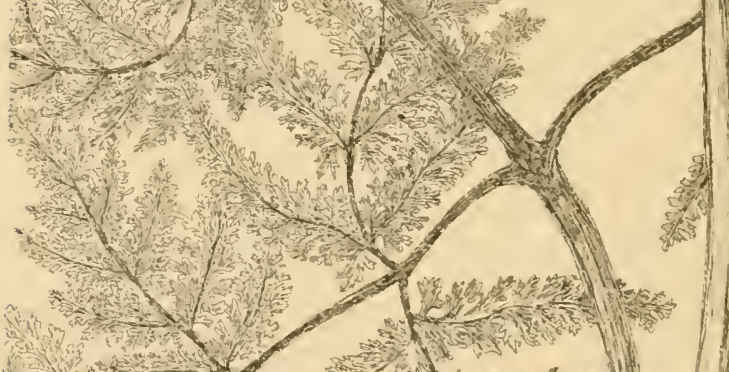

H.

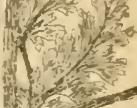

14)

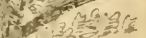
230

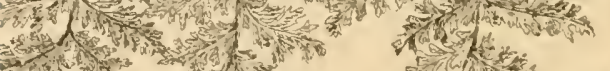
जी

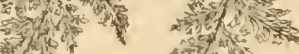

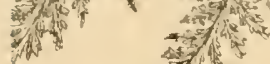

का.

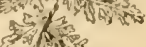
Silit: I)

क्षा⿰⿺𠃊一兀)

(8)
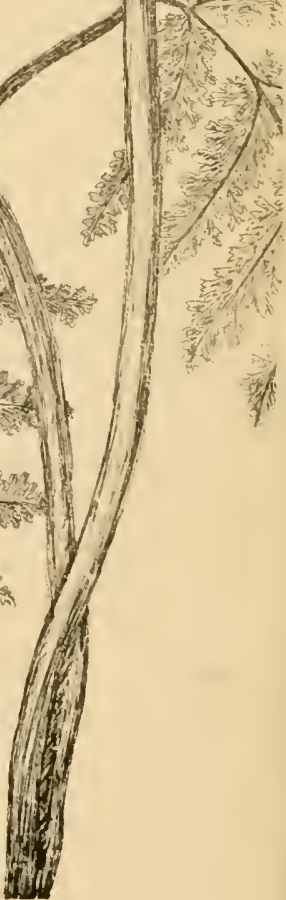
Plate LViII.

BOTRYCHIUM TERNATUM. Var. Dissectum. Milde.

Finely - Dissected Moonwort.

The general outline and appearance of this fern is similar to the plant last described. The sterile frond is ternate, with lanceolate pinnæ; but instead of being crisp and wavy they are finely dissected, so as to form the most delicate lanceolate teeth. I have attempted to reproduce this dissected appearance of the frond in the etching, but the lines were so minute and delicate that the Plate conveys but an imperfect idea of its finely-cut foliage.

As far as I have observed, this fern is rather rare in Kentucky. A beautiful specimen of this variety was sent to me by Mrs. J. F. Bullitt, who collected it on the banks of Beargrass Creek, about two miles from Louisville, where it was found with the Var. obliquum and the B. Virginianum, both common in that locality. All the specimens of this variety which I have seen are strong-growing plants, with a well-developed fertile frond, bearing fruit in abundance. The stem is stout and fleshy. When it is carefully dried and mounted it is a beautiful specimen for the herbarium, the finely-lacerated outline of the lobes showing to great advantage.

The texture is not so coarse as in the Var. obliquum, being more membranaceous, but less thin and delicate than that of the Virginia Moonwort. The vernation in this variety is similar to that of the Var. obliquum.

As in the previous Plate, the plant is represented natural size, with the fertile segment removed. 

Plate LIX.

\section{OPHIOGLOSSUM. Linnæus.}

\section{ADDER's ToNGue.}

Gen. Char.-Sporangia sessile, naked, coherent in two ranks; fronds with sterile and fertile segments, the former simple, ovate, oblong-the latter forming a simple spike; veins reticulated.

This is the typical genus of the sub-order Ophioglossacer. The distinctive characters of the genus are somewhat like those of Botrychia. The sporangia, however, instead of being arranged in the form of a compound panicle, occupy a simple spike. These sporangia or sporecases are sessile, and situated near the apex of a kng cylindrical stem, in two ranks. The spore-cases are opaque, discharging, when ripe, a number of minute spores from a transverse slit, forming two valves.

According to Hofmeister, the young frond makes its appearance near the depressed, almost flat end of the stem, in the form of a slender conical knob, from the fore side of which a fleshy, flat, stipule-like excrescence, as in Marattia, is produced. This cellular mass develops in breadth more vigorously than the part of the frond which is situated above its place of attachment. It embraces about two fifths, and the frond about one third of the zone of the stem upon which they both stand.* The sporangia of Ophioglossum agree with those of all the Vascular Cryptogams in the one point of belonging to the leaves, although the history of their development is not as yet accurately known (Sachs). Figure $\mathbf{I}$ of the Plate is from nature; figures 2, 3, and 4 are from Hooker and Bauer.

* See Hofmeister, l. c. p. $3^{12}$. 


\section{Plate Lix.}

\section{OPHIOGLOSSUM VULGATUM. Linnæus.}

\section{Common AdDeR's Tongue.}

This species of Ophioglossum is the only one I have been able to find in Kentucky, although Dr. Short, a very trustwortly botanist, states that he found the O. bulbosum, (Michx.) in this State, giving "low grounds" as its habitat.* The latter, however, has been reduced by Prof. Eaton to a variety of $\mathrm{O}$. vulgatum, called Crotalophoroides from Walker's species. $\dagger$ I am inclined to believe, from my own observation, that all the Kentucky forms may be properly referred to $\mathrm{O}$. vulgatum, which is an exceedingly variable species, the simple leaf of the sterile frond being sometimes oval, sometimes ovate-oblong, or even lanceolate. The root-stocks, generally fibrous, are occasionally inclined to be bulbous, by which Dr. Short was probably misled in his determination of the species. For a full account of the development of the vegetative organs of the $\mathrm{O}$. vulgatum, the reader is referred to Hofmeister. The stem is never branched, and the comparatively thickened root-stock but rarely. Unlike most ferns, the veins are finely reticulated, not free or forked. This exceptional mode of the venation is common to all the Ophioglossacer.

Prof. Hussey says that he found this fern near Glasgow Junction, in Barren County, where it grew in abundance. The exact locality is within a few rods of the Lithographic Stone-Quarry, near the road leading from Glasgow Junction

* See Riddell, 1. c. p. 107, and Short, Cat. of the Phenog. Pl, and Ferns of Kentucky, p. 10.

† Chapman's Flora of Southern States, p. 599.

$\ddagger$ Ray Society, 1. c. p. 312, et seq. 

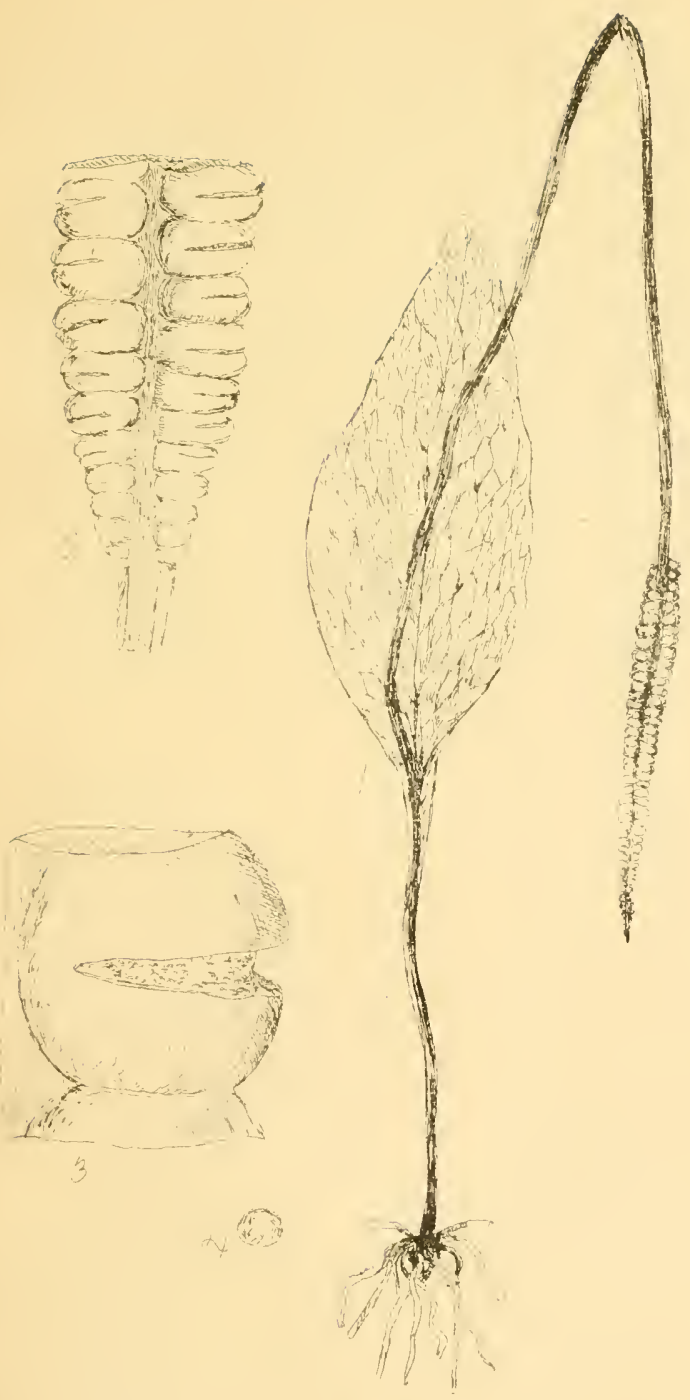

W 

to Mammoth Cave. He has observed that it sends up several fronds from the root-stock, "from near the base of that of the previous year, especially if the first fronds have been destroyed." He remarks, also, that the statement that it grows in "bogs and meadows" should be modified, as he has never found it in such situations, but in rich woods. The soil near Glasgow Junction, where it grew, was a rather dry, compact clay. It is by no means common in the State. Some good specimens of this plant were collected by Dr. Crosier, near the mouth of Wyandotte Cave, in Indiana, five miles from the Ohio River.

The leaf becomes very much attenuated in drying, and, when decolorized, furnishes beautiful objects for the microscope.

Figure I, a plant, natural size; figure 2, a portion of a spike; figure 3 , a sporangium; figure 4 , a spore; figures 2 , 3 , and 4 , are magnified views (from Hooker and Bauer). 


\section{A P PEN DIX.}

\section{DESCRIPTION OF PLATE LX.}

[From Davenport's Monograph on the Vernation IN Botrychia, in Torrey Botanical Bulletin, vol, vi, January, 1878.]

\section{VERNATION IN BOTRYCHIA.}

I. VERnATION WHOLLY STRAight:

I. B. simplex, Hitchcock. Bud smooth. Apex of fertile and sterile frond erect. Figure 3 .

2. VERnATION PARTLY INCLINED, in one or both portions.

I. B. Lunaria, Swartz. Bud smooth. Apex only of sterile frond bent over and outside of the nearly straight fertile frond. Segments of sterile frond arranged nearly perpendicularly. Figure 4 .

2. B. boreale, Milde. Bud smooth. Apex of sterile frond bent over inside of the nearly erect fertile frond. Sterile segments arranged on an angle. Figure 5 .

3. B. matricaricefolium, A. Br. Bud smooth. Apex of both fronds turned down. Sterile frond clasping the fertile, with its apex overlapping the whole. Figure 6.

4. B.ternatum, Swartz. Bud pilose. Apex of both fronds bent down, with a slight curve inward. Figures 8 and 9 .

3. Vernation wholly inclined, in the fertile frond recurved.

I. B. lanceolatum, Angstrôm. Bud smooth. Fertile frond recurved its whole length, the shorter sterile frond reclined upon it. Figure 7 .

2. B. Virginianmm, Swartz. Bud pilose. Fertile frond recurved its whole length with the longer sterile frond reclined upon it. Figure Io. 

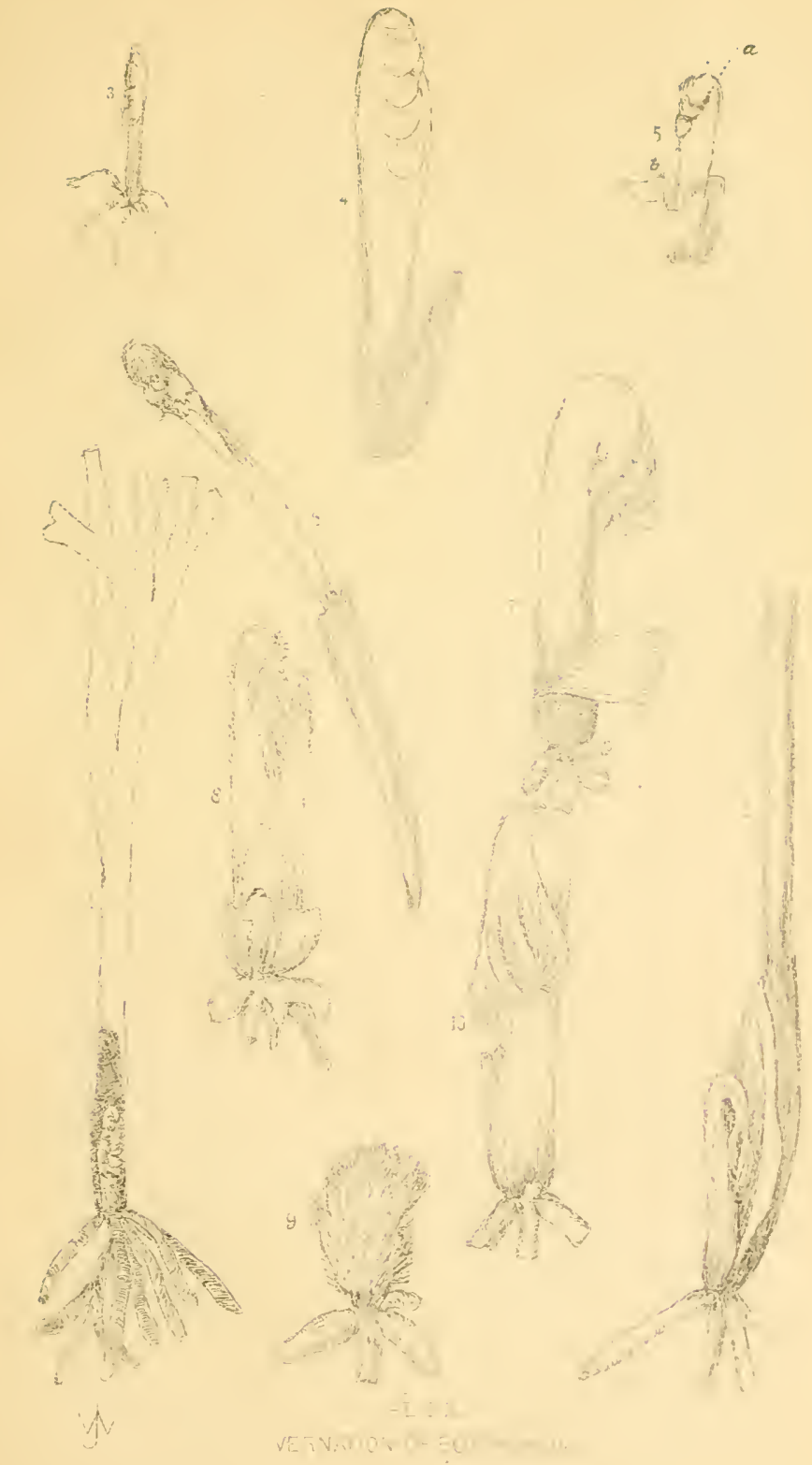



\section{N D EX.}

The more important references are in heavy faced type; obsolete names in italic type.

Adder's Tongue, 12, 25, 147.

Adiantum, 28, 39, 45.

Chilense, 39.

Farleyense, 39 .

pedatum, $8,39,40$.

Allosorus, 28, 5 I.

Antheridia, 19.

Appendix, 15 I.

Archegonia, 19.

Aspidiex, 29, 79, 85.

Aspidium, 29, 79, 85.

acrostichoides, 99.

cristatum, 93.

Goldianum, 95.

marginale, 85, 97.

Noveboracense, 89.

obtusum, 113.

spinulosum, 9r, 93 .

spinulosum, v. intermedium,

91.

Thelypteris, 87.

Asplenieæ, 28, 53 .

Asplenium, 28, 53.

angustifolium, 69, 7I.

Bradleyi, 8, 57.

ebeneum, 58, 63, 77 .

ebenoides, 53 .

Filix-fœmina, 73.

montanum, 57, 58, 65 .
Asplenium pinnatifidum, 55, 58, $59,61,77$.

Ruta-muraria, 67.

thelypteroides, 71.

Trichomanes, 61, 63, 65 .

Athyrium, 73.

Barren County, 47, 123, 149.

Bear Creek, 58.

Beargrass Creek, 52, 113,145 .

Beech Fern, 69, 81, 83 .

Bee Spring, 58.

Bell County, 37 .

Big Clifty, 59, 65, 91.

Bladder Fern, 17, 101, 113.

Boone County, 55 .

Botrychium, 139, I40, I5I.

boreale, I $5 \mathrm{I}$.

gracile, $\mathbf{1} 4 \mathbf{I}$.

lanceolatum, 151 .

Lunaria, I40, I5I.

lunarioides, $\mathbf{1 4 4}$.

matricariæfolium, $15 \mathrm{I}$.

obliquem, 144 .

simplex, $15 \mathrm{I}$.

ternatum, I5I.

ternatum, v. dissectinn, $\mathbf{1 4 5}$. ternatum, v. obliquum, 143 , 145 . 
Botrychium Virginianum, I40, $141,145,151$.

Bracken, 13, 43 .

Bristle Fern, 123.

Buds, 19.

Bulbous Bladder Fern, 105.

Bullitt County, 74, 9I.

Camptosorus, 28, 75.

Camptosorus rhizophyllus, 77.

Carter County, 55, $\mathbf{2 3}$.

Cheilanthes, 28, 45.

fragrans, 45 .

tomentosa, 49.

vestita, $\mathbf{4 7}, 50$.

Christmas Fern, 99.

Cinnamon Fern, 137.

Classification, 24.

Clayton's Flowering Fern, 135.

Cliff-brake Fern, 5I, 52.

Climbing Fern, 8, 129.

Clothed Lip-fern, 47.

Collecting and Drying, 21.

Columella, 26.

Common Adder's Tongue, 149.

Bladder Fern, 103.

Bracken, 43.

Polypody, 35.

Crab Orchard, 73.

Crested Shield Fern, 93.

Cryptogamia, II.

Cultivation, 15.

Cumberland Gap, 37, 49.

Cyatheacex, 25.

Cystopteris, 29, 101.

bulbifera, I0I, 105.

fragilis, 101, 103, I13.

montana, IOI.

Davalliex, 29, I 7 .
Diamond Cave, 48 .

Dicksonia, 117.

Dicksonia punctilobula, 119.

Double-staining, $8_{3}$.

Ebony Spleenwort, 63.

Edmonson County, 37, 47, 55,

$58,91,93,123$, I I 9 .

Elba Woodsia, 115.

Elk Lick, 37.

Equisetum, 87.

Estill County, 47, 55 .

Fertilization, 18.

Finely-dissected Moonwort, 145.

Flowering Fern, 1I, 133.

Fossil Ferns, 10, 109, 127, 131.

Fronds, 12, 74, 99.

Fruit-dots, I 8 .

Genera and Species, 33 .

Geographical Distribution, 9.

Glasgow Junction, 149.

Gleicheniaceæ, 25.

Goldie's Shield Fern, 95.

Grayson County, 37, 55, 59, 65, 91.

Green River, 58.

Gymnogramme, 45 .

Hardin County, 37, 55 91.

Hart's Tongue, 77 .

Hymenophyllacer, 25, 26, 121 , I 23.

Hymenophyllum, 122.

Introduction, 7 .

Jefferson County, 9I. 
Kentucky River, 37, 67, 105.

Key to the Genera, 30.

Killarney Fern, 123.

Lady Fern, 7, 17, 69, 73, 9I, II 9.

Laurel County, 8, 35, 55, 91, 93 , 95, I23, I 25, I 29.

Leaf, 13, 14.

Lincoln County, 73 .

Little Rockcastle River, 95.

Liverworts, 124.

Lygodium, 127.

Lygodium Palmatum, 8, 129.

Madison County, 35 .

Maiden-hair Fern, 8, I7, 39, $40,69$.

Maiden-hair Spleenwort, 61.

Male Fern, Io.

Mammoth Cave, 37, 6I, I25, I5o.

Narattiaceæ, 25.

Marchantia, I 24.

Marion County, 37.

Marginal Shield Fern, 97.

Marsh Shield Fern, 87, 89.

Meeting Creek, 59.

Moonwort, 12, 25, 139.

Mounds, 17.

Mountain Spleenwort, 65.

Mounting, 22.

Narrow-leaved Spleenwort, 69, 71 .

Nephrodium lanosum, 49.

rufidulam, I 5 .

New York Shield Fern, 89.

Nolin Creek, 38, 5S.
Oak Fern, Iog.

Obtuse-leaved Woodsia, 113.

Ohio River, 37, 52.

Oldham County, 37, 67, 91, 105.

Onoclea, 107.

Onoclea sensibilis, I I, 109.

Ophioglossaceæ, 25, 27, 131, I39.

Ophioglossum, 147.

Ophioglossum, bulbosum, I49.

vulgatum, 149.

vulgatum, v. Crotalophoroides, 149.

Osmund, 133 .

Osmunda, $87,131,141$.

Claytoniana, 135.

cinnamomea, 109, I35,

137.

interrupta, 135 .

regalis, II, I09, 133, I35.

Osmundaceæ, 25, 27.

Pelliea, 28, 4I, 51, 89.

Pellæa atropurpurea, 52.

Phegopteris, 29, 79.

Phegopteris, hexagonoptera, 83.

polypodioides, 81,83 .

Pine Hill, 129.

Pinnatifid Spleenwort, 55, 65.

Polypodiaceæ, 25, 26, 28, 107.

Polypodieæ, 28, 79 .

Polypodium, IO, I3, 2S, 33, 79,

II 5 .

incanum, 37.

obtusum, 113.

Phegopteris, 8I.

vulgare, 35 .

Prothallus, 19, 20.

Pterideæ, 28, $4 \mathrm{I}$. 
Pteris, 28, 41, 5I, 89.

Pteris aquilina, $13,14,43$.

Red River, 73.

Rockcastle County: 9, 35, 37, 55, S9, 91, 97, 135, 137.

Rockcastle River, 8, I24, I33. Springs, 93, I 23, I 29, I30.

Rock Springs, 37, 67, 105.

Root-stock, 13, 8I.

Rough Creek, 37, 55 .

Royal Fern, I2, 133, I35.

Scaly Polypody, 37.

Schizæaceæ, 25, 27, I27.

Scolopendrium, 28, 77 .

Scolopendrium officinarum, iv.

Selaginella convoluta, 38 .

Sensitive Fern, I I, I 7, 109.

Shield Fern, 85.

Short Cave, 48.

Sorus, i 8.

South Fork, 124.

Spiny Shield Fern, 91.

Spleenwort, 53.

Sporangia, I8, I9, 20, 26, I21.

Spores, 19.

Structure, 11.

Struthiopteris, 29.
Sweet Lick Knob, 47.

Sweet-scented Fern, I19.

Summer Fern, 69.

Ternate Moonwort 143.

Tree Ferns, 9, I 17.

Trichomanes, 7, 29, 121, 130.

Trichomanes radicans, 8, 58, 122.

\section{3.}

Unfolding of the Leaf, I 2, I 4,7 , I 2 I, I 45, I 47, I49, 151.

Veins, I 2.

Vernation, 7I, I2I, I45, 151.

Virginia Moonwort. 141, 143, I45, I 5 I.

Walking-leaf Fern, 77.

Wall-rue Fern, 67.

Wardian Cases, I 5.

Wet Woods, I33. 137.

What is a Fern? 11.

Winter Fern, 99.

Woodwardia, 28.

Woodsia, 111.

Woodsia Ilvensis, I13, 115. obtusa, 113.

Woolly Lip Fern, 49. 


\title{
The FERNS of NORTH AMERICA:
}

\author{
ILLUSTRATED BY SUPERBLY-COLORED PLATES.
}

\section{Text by Professor Daniel C. Eaton, of Yale College.}

ILLUSTRATIONS BY MR. JAS. H. EMERTON.

DROF. EATON'S herbarium of Ferns is the largest in America, and he is constantly in receipt of additional plants from all parts of the country. He is therefore in a position to better conduct the work and furnish the necessary specimens for illustrations than any other person. Besides the labors of Prof. Eaton and Mr. Emerton, Dr. Gray, of Cambridge, has expressed an interest in the undertaking, and kindly offered the use of the extensive herbarium of the Botanical Gardens for consultation. The Massachusetts Horticultural Society has also freely offered the use of the Davenport herbarium of Ferns. The publishers will also have the assistance of Mr. J. Robinson, well known as a Fern specialist. Mr. George E. Davenport and Mr. Chas. E. Faxon, of Boston, Mrs. Cooper, of Santa Barbara, Cal., and others in various parts of the country, have kindly offered their assistance.

The subscription price will be \$I.oo per part, which, it is believed, is lower than any work of the same nature and quality yet published.

Botanists, who desire to inspect the work before subscribing, will receive a sample plate and text by mail, upon application.

For the benefit of any young botanists who do not feel able to pur. chase the work, the publisher offers an opportunity to obtain a copy by procuring a few subscribers in their vicinity. Any lady can easily obtain four subscribers for the work among her friends, and thus secure a copy for nothing.

\section{S. E. CASSINO,}







$$
\begin{aligned}
& 4 \sqrt{27} \\
& 74 x
\end{aligned}
$$

$$
(13+1=7
$$



